\title{
23. STABLE ISOTOPIC AND CARBONATE STRATIGRAPHY OF THE LATE PLIOCENE AND PLEISTOCENE OF HOLE 704A: EASTERN SUBANTARCTIC SOUTH ATLANTIC ${ }^{1}$
}

\author{
David A. Hodell ${ }^{2}$ and Paul F. Ciesielski
}

\begin{abstract}
We studied the stable isotopic and carbonate stratigraphy of ODP Hole 704A to reconstruct the paleoceanographic evolution of the eastern subantarctic sector of the South Atlantic Ocean. Site 704 is well positioned with respect to latitude $\left(46^{\circ} 52.8^{\prime} \mathrm{S}, 7^{\circ} 25.3^{\prime} \mathrm{E}\right)$ and bathymetry $(2532 \mathrm{~m})$ to monitor past migrations in the position of Polar Front Zone (PFZ) and changes in deep-water circulation during the late Pliocene-Pleistocene.

Several important changes occurred in proxy paleoceanographic indicators across the Gauss/Matuyama boundary at $2.47 \mathrm{Ma}$ : (1) accumulation rates of biogenic sedimentary components increased by an order of magnitude (Froelich et al., this volume); (2) planktonic $\delta^{18} \mathrm{O}$ values increased by an average of $0.5 \%$; (3) the amplitude of the benthic $\delta^{18} \mathrm{O}$ signal increased; (4) the accumulation rate of ice-rafted detritus increased several fold (Warnke and Allen, this volume); and (5) carbon isotopic ratios of benthic foraminifers decreased by $0.5 \%$, as did the $\delta^{13} \mathrm{C}$ of the fine-fraction carbonate by $1.5 \%$ (Mead et al., this volume), but no change occurred in planktonic foraminiferal $\delta^{13} \mathrm{C}$ values.

Most of these changes are consistent with more frequent expansions and contractions of the PFZ over Site 704 after $2.47 \mathrm{Ma}$, bringing cold, nutrient-rich waters to $47^{\circ} \mathrm{S}$ that stimulated both carbonate and siliceous productivity. The synchronous increase in $\delta^{18} \mathrm{O}$ values and ice-rafted detritus accumulation in Hole 704A indicates that the $2.4 \mathrm{Ma}$ paleoceanographic event included ice volume growth on both Antarctica and Northern Hemisphere continents. The decrease in benthic $\delta^{13} \mathrm{C}$ values indicates that the ventilation rate of Southern Ocean deep water decreased and the nutrient content increased during glacial events after $2.5 \mathrm{Ma}$. At the Gauss/Matuyama boundary, benthic $\delta^{13} \mathrm{C}$ values of the Southern Ocean shifted toward those of the Pacific end member, indicating a decrease in the relative mixing ratio of Northern Component Water and Circumpolar Deep Water.

During the early Matuyama ( 2.3 to $1.7 \mathrm{Ma})$, the PFZ generally occupied a southerly position with respect to Site 704 and carbonate productivity prevailed. Exceptions to these general conditions occurred during strong glacial events of the early Matuyama (e.g., isotopic stages 82, 78, 74, and 70), when the PFZ migrated to the north and opal sedimentation predominated at Site 704 . At $1.7 \mathrm{Ma}$, the PFZ migrated toward the equator and occupied a more northerly position for a prolonged interval between $\sim 1.7$ and $1.5 \mathrm{Ma}$. Beginning at $\sim 1.5-1.4 \mathrm{Ma}$, surface and bottom water parameters $\left(\delta^{18} \mathrm{O}, \delta^{13} \mathrm{C}, \% \mathrm{CaCO}_{3}\right.$, and \%opal) in the subantarctic South Atlantic became highly correlated such that glacial events $\left(\delta^{18} \mathrm{O}\right.$ maxima) corresponded to $\delta^{13} \mathrm{C}$ and carbonate minima and opal maxima. This pattern is typical of the correlation found during the latest Pleistocene in the Southern Ocean (Charles and Fairbanks, in press). This event coincided with increased suppression of Northern Component Water during glacial events after 1.5 Ma (Raymo et al., 1990), which may have influenced the climatology of the Southern Hemisphere by altering the flux of heat and salt to the Southern Ocean).
\end{abstract}

\section{INTRODUCTION}

The development and intensification of Northern Hemisphere glaciation during the late Pliocene represented the crossing of a major threshold in the Earth's ocean-climate system. Since $\sim 2.4 \mathrm{Ma}$, the Earth's climate has been in a glacial mode characterized by over 50 repetitive glacialinterglacial cycles (Ruddiman et al., 1986b, 1989; Raymo et al., 1989). Records of ice-rafted detritus and oxygen isotopes from the North Atlantic indicate that Northern Hemisphere glaciation developed gradually over several hundred thousand years during the late Pliocene. Oxygen isotopic records from the North Atlantic indicate a series of brief $\delta^{18} \mathrm{O}$ maxima beginning at $\sim 3.1 \mathrm{Ma}$ (Keigwin, 1986), culminating in a $30 \%$ increase in signal amplitude at $\sim 2.4 \mathrm{Ma}$ (Raymo et al., 1989). It is this date of $2.4 \mathrm{Ma}$ that has been generally accepted as the onset of Northern Hemisphere glaciation (Shackleton et al., 1984), but this event is better viewed as an intensification of ice-sheet growth that permitted extensive ice rafting to be

\footnotetext{
${ }^{1}$ Ciesielski, P. F., Kristoffersen, Y., et al., 1991. Proc. ODP, Sci. Results, 114: College Station, TX (Ocean Drilling Program).

${ }^{2}$ Department of Geology, University of Florida, Gainesville, FL 32611.
}

delivered to the open North Atlantic Ocean (Raymo et al., 1989).

Although this late Pliocene climatic transition is well studied in the North Atlantic, the event is poorly known from the Southern Hemisphere. For example, it is uncertain what proportion of the increase in the $\delta^{18} \mathrm{O}$ signal is due to ice growth on Antarctica and what proportion is attributable to the expansion of ice sheets on Northern Hemisphere continents. The paucity of data from the Southern Ocean has been due mainly to the lack of recovery of minimally disturbed, carbonate-bearing sequences from the high-latitude Southern Ocean. On Leg 114 of the Ocean Drilling Program (ODP), we retrieved a nearly complete Pliocene-Pleistocene sequence of carbonate-siliceous sediments at Site 704 on the Meteor Rise in the eastern subantarctic South Atlantic $\left(46^{\circ} 52.8^{\prime} \mathrm{S}\right.$, $\left.7^{\circ} 25.3^{\prime} \mathrm{E}\right)$. This site is well suited for paleoceanographic study of the late Pliocene-Pleistocene because of its latitudinal and bathymetric $(2532 \mathrm{~m})$ position, relatively high sedimentation rates, mixed carbonate-siliceous lithology, and continuous core recovery by minimal disturbance coring techniques in two offset holes (704A and 704B).

The stable isotopic and carbonate stratigraphy was produced for Hole 704A to study the paleoclimatic evolution of the subantarctic South Atlantic during the late Pliocene and 
Pleistocene. By comparing the Southern Hemisphere results from Site 704 with existing records from the high-latitude North Atlantic and other regions, we seek to define the role of the Southern Ocean in the pronounced climatic changes that occurred during the late Pliocene and Pleistocene. The relative chronology of events is important for understanding the interhemispheric timing of climatic and oceanographic changes. For example, were climatic events during the late Pliocene coupled and synchronous between the polar oceans? Did climate or oceanographic changes in the Southern Hemisphere lead or lag those in the Northern Hemisphere? If the polar oceans were coupled, what was the mechanism(s) for interhemispheric feedback? These questions can only be addressed with high-resolution comparisons of isotopic and sedimentologic data between the polar oceans. In addition, comparison of benthic carbon isotopic records between the Southern Ocean and other basins can provide information about deep ocean circulation and ventilation rates (Oppo and Fairbanks, 1987). Because our study of Site 704 is still in progress, this publication should be considered as a preliminary report of our findings, and many of our objectives can only be met with additional work.

\section{SITE LOCATION AND OCEANOGRAPHY}

Site 704 is positioned in an area of strong hydrographic gradients associated with the Antarctic Polar Front Zone (PFZ) (Fig. 1). The PFZ is defined as the area between the Subantarctic Front and the Antarctic Polar Front, and its geographic position generally lies at about $45^{\circ} \mathrm{S}$ with a latitudinal spread of about $2.5^{\circ}$ to either side (Fig. 1; Lutjeharms, 1985). The average width of the PFZ in the eastern subantarctic South Atlantic is $670 \mathrm{~km}$ (Lutjeharms, 1985), and it marks a steep gradient in many hydrographic parameters, including sea surface temperature, salinity, $\delta^{18} \mathrm{O}$, total dissolved inorganic carbon $\left(\Sigma \mathrm{XO}_{2}\right), \delta^{13} \mathrm{C}$, and nutrient concentrations, among others.

The proximity of Site 704 to the PFZ suggests that its sedimentary record should be highly sensitive to past changes in the position and strength of the PFZ. In regions where surface sediments are above the carbonate compensation depth (CCD), the Subantarctic Front coincides with a litho-

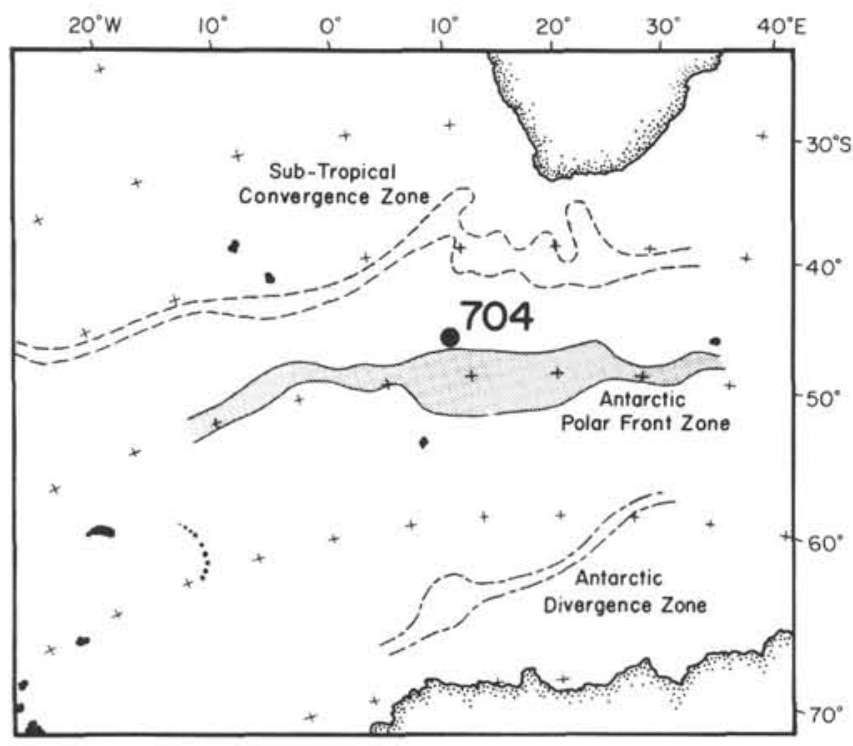

Figure 1. Position of ODP Site 704 in the eastern subantarctic South Atlantic relative to the major hydrographic fronts (modified after Lutjeharms, 1985). logic boundary separating mixed siliceous/calcareous oozes to the north from silica-rich facies to the south (Hays et al., 1976). South of the Antarctic Polar Front, sediments consist of silty diatomaceous clay with the clay component becoming progressively dominant to the south (Burckle and Cirilli, 1987).

The sediments of Site 704 consist of varying admixtures of opal, calcium carbonate, and terrigenous components (Froelich et al., this volume). Sediments contain abundant and well-preserved specimens of both calcareous and siliceous microfossil groups. Sedimentation was controlled by a complex interplay of carbonate and opal production, dilution, and dissolution. Assuming no changes in carbonate saturation of the bottom waters, one would expect biogenic silica to dominate when Site 704 was positioned within the PFZ. In contrast, carbonate should prevail when the PFZ was south of Site 704. Although the water depth of Site $704(2532 \mathrm{~m})$ was above the CCD throughout most of the Neogene, fluctuations in the lysocline, and hence the carbonate saturation of deep waters, did affect sediment composition at Site 704.

The PFZ is a region of steep isotopic gradient in surface equilibrium $\delta^{18} \mathrm{O}$ values of calcite because of the temperature dependence of the $\delta^{18} \mathrm{O}$ of precipitated calcite. Between $41^{\circ}$ and $60^{\circ} \mathrm{S}$, the $\delta^{18} \mathrm{O}$ of equilibrium calcite increases by $3 \%$, which represents nearly half of the predicted equator to pole gradient in $\delta^{18} \mathrm{O}_{\text {calcite }}$ (Charles and Fairbanks, 1990). Clearly, even subtle latitudinal translations of the boundaries of the PFZ system could produce large changes in the $\delta^{18} \mathrm{O}_{\text {calcite }}$ as recorded by calcareous plankton.

The PFZ also marks a region of steep gradients in the $\delta^{13} \mathrm{C}$ of $\mathrm{\Sigma CO}_{2}$ of surface water (Kroopnick, 1974). South of the Antarctic Convergence, deep water with high $\mathrm{CO}_{2}$ and nutrients is pumped to the surface. The upwelling of deep water produces a decrease in the $\delta^{13} \mathrm{C}$ of $\mathrm{\Sigma CO}_{2}$ of surface water because the component of $\mathrm{CO}_{2}$ that is derived from the respiration of organic matter is depleted in ${ }^{13} \mathrm{C}$ by some $20 \%-25 \%$. Gas exchange between surface water and the atmosphere is also important for controlling the distribution of $\delta^{13} \mathrm{C}$ of $\Sigma \mathrm{CO}_{2}$ in the Southern Ocean. The highest phosphatecorrected $\delta^{13} \mathrm{C}$ of $\Sigma \mathrm{CO}_{2}$ values in the Southern Ocean are found at $\sim 50^{\circ} \mathrm{S}$ associated with the Antarctic Polar Frontal boundary, presumably because persistently high gas-exchange rates occur between surface water and the atmosphere at the PFZ (Charles and Fairbanks, 1990). Carbon isotopic values rapidly decrease north and south of the northern boundary of the PFZ.

A vertical salinity profile along a north-south transect across the Agulhas Basin clearly shows the tongue of highsalinity Northern Component Water (NCW) as it penetrates into the circumpolar region, inserts itself into the Circumpolar Current, and upwells at the Antarctic Divergence (Fig. 2). Site $704(2532 \mathrm{~m})$ is positioned directly within the mixing zone between NCW and Circumpolar Deep Water (CPDW). As a result, the stable isotopic record of benthic foraminifers at Site 704 should be highly sensitive to changes in the relative mixing ratios of NCW and CPDW in the Southern Ocean (Oppo and Fairbanks, 1987).

\section{METHODS}

\section{Stable Isotopes}

About 100 specimens of sinistrally coiled Neogloboquadrina pachyderma from the $>150-\mu \mathrm{m}$ size fraction of each sample were analyzed for oxygen and carbon isotopic ratios. In high-productivity regions, the depth habitat of this species is thought to include the entire surface mixed layer (Reynolds and Thunell, 1985). N. pachyderma deposits its test with a 


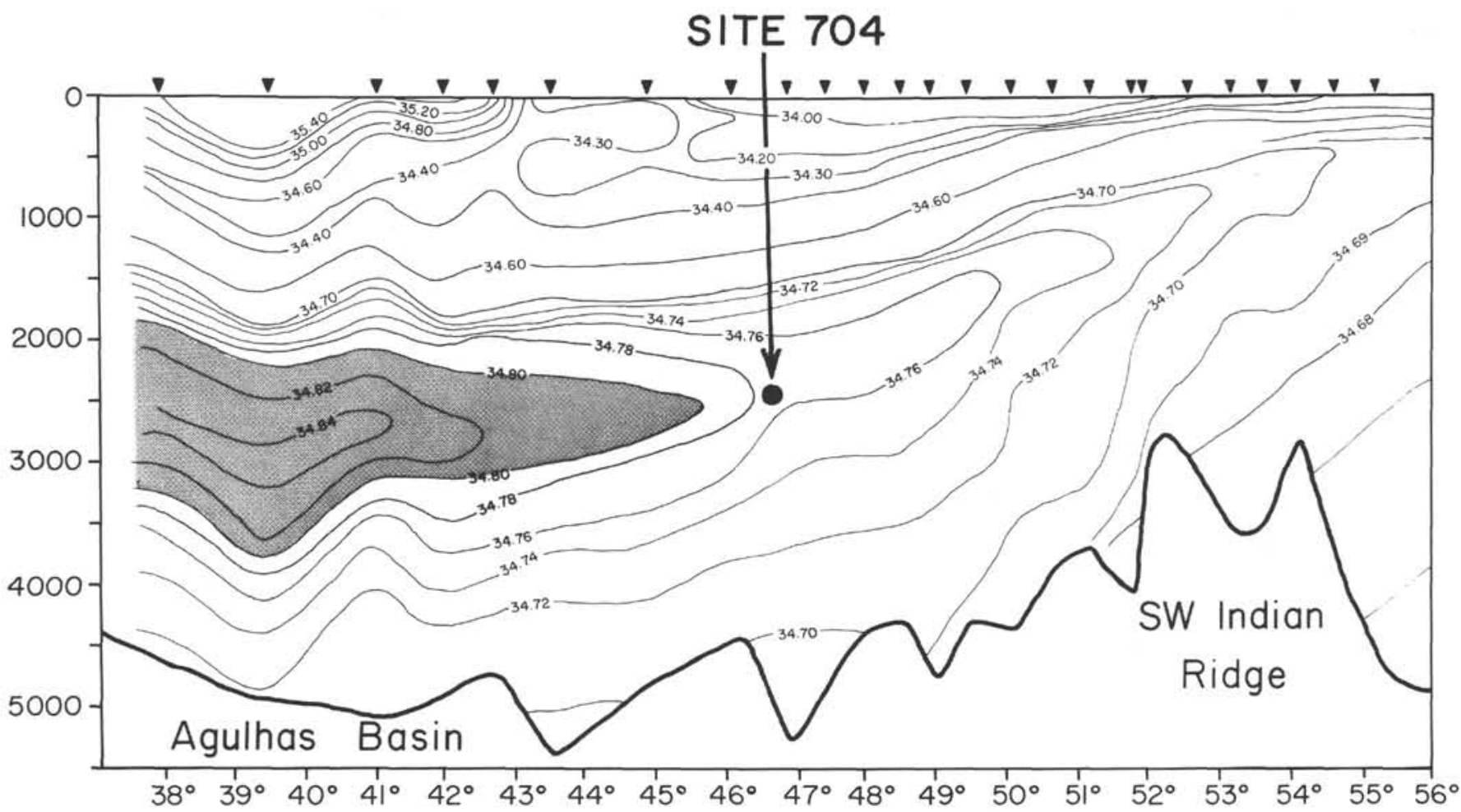

Figure 2. Vertical salinity profile (contoured in parts per thousand) along a north-south transect (from $38^{\circ}$ to $56^{\circ} \mathrm{S}$ ) in the eastern subantarctic-antarctic sector of the Southern Ocean (modified after Gordon and Molinelli, 1986). Site 704 is located in a mixing zone between North Atlantic Deep Water (NADW) and Circumpolar Deep Water. Note that the tongue of high-salinity NADW penetrates into the circumpolar region, inserts itself into the Circumpolar Current, and upwells at the Antarctic Divergence.

constant $0.4 \%$ offset from the predicted oxygen isotopic equilibrium of calcite across a temperature range of $-1^{\circ}$ to $+9^{\circ} \mathrm{C}$ in the Southern Ocean (Labeyrie et al., 1986; Charles and Fairbanks, 1990). The $\delta^{13} \mathrm{C}$ of $N$. pachyderma is also out of isotopic equilibrium from the $\delta^{13} \mathrm{C}$ of $\Sigma \mathrm{CO}_{2}$. In the subantarctic South Atlantic, Charles and Fairbanks (1990) found a constant offset of $-1 \%$ o between $\delta^{13} \mathrm{C}$ of $N$. pachyderma and $\delta^{13} \mathrm{C}$ of $\Sigma \mathrm{CO}_{2}$.

Benthic foraminiferal analyses were made on mixed species of Planulina wuellerstorfi, Cibicidoides kullenbergi, and Cibicidoides spp. from the $>150-\mu \mathrm{m}$ size fraction. The oxygen isotopic disequilibrium between $P$. wuellerstorfi/C. kullenbergi and the predicted $\delta^{18} \mathrm{O}$ of equilibrium calcite is $-1.01 \%$ to $-1.02 \%$ (Graham et al., 1981), whereas the carbon isotopic disequilibrium between $P$. wuellerstorfi and/or $C$. kullenbergi and the $\delta^{13} \mathrm{C}$ of $\Sigma \mathrm{CO}_{2}$ is near zero (Graham et al., 1981).

Samples for isotopic analysis were either roasted in vacuo at $400^{\circ} \mathrm{C}$ for $1 \mathrm{hr}$ or were treated with hydrogen peroxide to oxidize organic matter. Paired analyses of roasted and peroxide-treated samples showed no significant difference in either $\delta^{18} \mathrm{O}$ or $\delta^{13} \mathrm{C}$ values for the two pretreatments. Samples were then reacted in a common acid bath of orthophosphoric acid at $70^{\circ} \mathrm{C}$ using a VG Isogas Autocarbonate preparation system. Isotopic ratios of purified $\mathrm{CO}_{2}$ gas were measured on-line with a triple-collector VG Isogas Precision Isotope Ratio Mass Spectrometer (PRISM). Isotopic ratios are expressed in standard delta notation relative to PDB. The calibration of University of Florida reference gas to PDB is given in Hodell et al. (1989). Analytical precision, estimated by the standard deviation (one sigma) of routine analysis of a powdered carbonate standard (Carrara Marble), was $\pm 0.13 \%$ for $\delta^{18} \mathrm{O}$ and $\pm 0.04 \%$ for $\delta^{13} \mathrm{C}$. All isotopic results are reported in Tables 1 and 2.

\section{Carbonate Stratigraphy and Sample Spacing}

Approximately 1500 samples were measured for carbonate content in Hole 704A. The methods and tabulation of carbonate and opal analyses are given in Froelich et al. (this volume). The percent opal content of the sediments is highly inversely correlated with percent carbonate (Froelich et al., this volume). The sample spacing for carbonate analyses is about 20 $\mathrm{cm}$ throughout the late Pliocene and Pleistocene, and time resolution varies because of changes in the sedimentation rate. Temporal spacing is roughly $9000 \mathrm{yr}$ for the Gauss and Gilbert Chrons, 1200 yr for the early Matuyama (2.47-2.25 $\mathrm{Ma}$ ), and $3000 \mathrm{yr}$ for the middle and late Matuyama (2.25-1.1 $\mathrm{Ma}$ ). The sample spacing for planktonic and benthic isotopic analyses is significantly greater than that of carbonate, which makes comparison of the isotopic and carbonate data difficult in some intervals.

\section{STRATIGRAPHY}

The stratigraphic framework adopted herein is based on identification of magnetic polarity reversal boundaries by Hailwood and Clement (this volume) and their respective ages from Berggren et al. (1985). The correct identification of the Gauss/Matuyama boundary in Hole $704 \mathrm{~A}$ is critical to this study because it is the datum level that is used for the correlation of events between Site 704 and other sites in the North Atlantic. The Gauss/Matuyama boundary has been placed at the polarity reversal at $168.72 \mathrm{~m}$ below seafloor (mbsf) in Hole 704A (Hailwood and Clement, this volume). Because this level falls at the core break between Cores 
$114-704 \mathrm{~A}-18 \mathrm{X}$ and $114-704 \mathrm{~A}-19 \mathrm{X}$, it is likely that some time is missing at the boundary.

Different microfossil groups provide conflicting biostratigraphic results with respect to the placement of the Gauss/ Matuyama boundary. The results from radiolarians suggest that the boundary should occur higher in the section (i.e., above $168.72 \mathrm{mbsf}$ ). For example, the first-appearance datum (FAD) of Cycladophora davisiana (dated at $2.6 \mathrm{Ma}$ ) occurs at $158 \mathrm{mbsf}$, whereas the last-appearance datums (LADs) of Desmospryis spongiosa and Helothus vema (dated at $2.45 \mathrm{Ma}$ ) occur between 148.9 and 150.3 mbsf.

In contrast, the diatom datum levels support placement of the Gauss/Matuyama boundary at 168.72 mbsf. These datum levels were determined by quantitative analyses of species abundances in several Southern Ocean sections, including piston cores E50-33 and IO 7-6 and Deep Sea Drilling Project (DSDP) Site 514 (Müller et al., this volume). These levels include the last abundant appearance datum (LAAD) of more than $5 \%$ of Nitzschia weaveri (170 mbsf; $2.63 \mathrm{Ma}$ ), the LAAD (10\%) of Cosmiodiscus insignis (168.39 mbsf; $2.49 \mathrm{Ma}$ ), and the LAAD (10\%) of Coscinodiscus vulnificus (141 mbsf; 2.29 $\mathrm{Ma})$. In Hole 704A, the LAAD of $N$. weaveri ( $2.63 \mathrm{Ma})$ occurs 2-3 $\mathrm{m}$ below the placement of the Gauss/Matuyama boundary. The LAAD of $C$. insignis $(2.49 \mathrm{Ma})$ is virtually synchronous with the Gauss/Matuyama boundary. This species is common to dominant in the late Gauss Chron and abruptly disappears with only rare to sparse occurrences in the early Matuyama (Ciesielski, 1983; Müller et al., this volume). Finally, the LAAD of $C$. vulnificus $(2.29 \mathrm{Ma})$ occurs about 28 $\mathrm{m}$ above the Gauss/Matuyama boundary. All diatom datum levels are consistent with placement of the Gauss/Matuyama boundary at 168.72 mbsf.

If the Gauss/Matuyama boundary does not occur at 168.72 mbsf, the only other possibility in the polarity record is at the top of a normal event that was identified between $\sim 153.5$ and $144 \mathrm{mbsf}$ in the shipboard whole-core magnetic data of Hole 704A (see Fig. 10B of Hailwood and Clement, this volume). Subsequent discrete paleomagnetic measurements from this interval indicate reversed polarity, however. In addition, the placement of the Gauss/Matuyama boundary above 168.72 mbsf creates a poor correlation between the magnetic polarity sequence in Hole $704 \mathrm{~A}$ and the geomagnetic polarity time scale. For lack of convincing evidence to the contrary, we accept the working hypothesis that the Gauss/Matuyama boundary occurs at $168.72 \mathrm{mbsf}$ in Hole 704A.

Age and depth levels are plotted for each of the identified polarity reversals in Figure 3. Sedimentation rates across the Gauss/Matuyama boundary increased by almost one order of magnitude, from $\sim 18 \mathrm{~m} / \mathrm{m}$.y. during the late Gauss to 100 $\mathrm{m} / \mathrm{m}$.y. during the early Matuyama. On average, sedimentation rates were about 3 to 4 times greater after $2.47 \mathrm{Ma}$ than before. Such rapid changes in the sedimentation rate are not uncommon for the Southern Ocean because the northern boundary of the PFZ marks a region of high productivity of both calcareous and siliceous microfossils that results in high fluxes of biogenic material to the seafloor. Because of high sedimentation rates, the early Matuyama of Site 704 is highly expanded and temporal resolution is high for paleoclimatic studies of the late Pliocene.

\section{RESULTS}

Although core recovery was high at Site $704(98.7 \%$ in the upper $180-\mathrm{m}$ interval in Hole $704 \mathrm{~A}$ ), missing sections at core breaks, double-cored intervals, and compressed and/or expanded sections are still common with the advanced piston corer and extended core barrel systems even under ideal conditions (Ruddiman et al., 1986a). Because the two offset

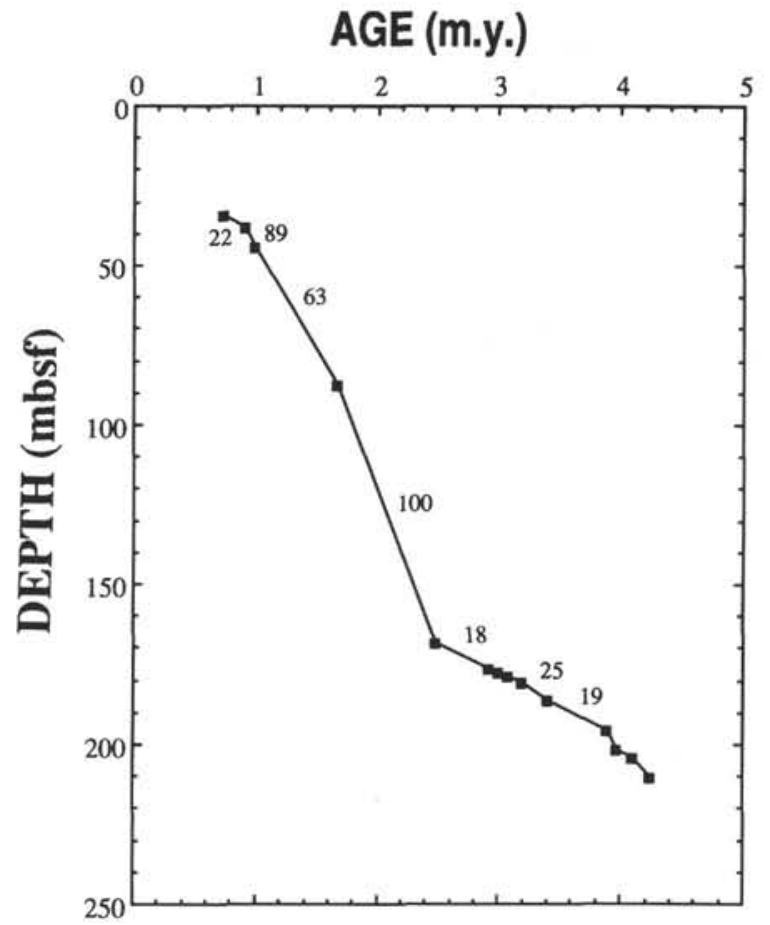

Figure 3. Age vs, depth plot for polarity reversal boundaries identified in Hole 704A by Hailwood and Clement (this volume). Sedimentation rates, in meters per million years, are given alongside selected segments. The Gauss/Matuyama boundary $(2.47 \mathrm{Ma})$ is placed at $168.72 \mathrm{mbsf}$. The sedimentation rate increases across this boundary from $\sim 18 \mathrm{~m} / \mathrm{m}$.y. in the latest Gauss to $100 \mathrm{~m} / \mathrm{m}$.y. in the early Matuyama. This increase reflects higher rates of production of biogenic calcite and opal as the PFZ migrated over Site 704 more frequently during the Matuyama than during the Gauss Chron.

Holes $704 \mathrm{~A}$ and $704 \mathrm{~B}$ were cored at Site 704 , the potential exists for obtaining a complete composite section by combining data from both holes, but correlation of these holes will have to await completion of carbonate analyses from Hole 704B (Froelich et al., this volume). Recognizing these shortcomings, we have plotted all parameters vs. sub-bottom depth in Hole 704A and have not converted to a composite depth or age scale. The positions of core breaks have been indicated on most figures. For ease of presentation and discussion, the isotopic and carbonate results are plotted in $30-\mathrm{m}$ segments beginning at 190 mbsf. Because of the soupy, disturbed nature of the upper $40 \mathrm{~m}$ in Holes 704A and 704B and the lack of an adequate chronology, we present these data in table format only.

\section{0-160 mbsf}

The interval from 190 to 160 mbsf spans the latest Gilbert through early Matuyama Chrons from $\sim 3.5$ to $2.4 \mathrm{Ma}$ (Fig. 4). The Gauss Chron was marked by significant variation in oxygen isotopes and carbonate content (Fig. 4). Two important carbonate minima occurred at $182.5(\sim 3.2 \mathrm{Ma})$ and 175.5 mbsf $(\sim 2.85 \mathrm{Ma})$. Three distinct benthic $\delta^{18} \mathrm{O}$ maxima occurred during the Gauss (indicated by triangles on Fig. 4), with estimated ages of $3.16,3.0$, and $2.88 \mathrm{Ma}$, respectively.

Across the Gauss/Matuyama boundary at $168.72 \mathrm{mbsf}$ ( 2.47 $\mathrm{Ma})$, planktonic $\delta^{18} \mathrm{O}$ values increased by an average of $\sim 0.5 \%$ (Fig. 4) whereas the benthic $\delta^{18} \mathrm{O}$ signal increased by $\sim 0.25 \%$ on average. Benthic $\delta^{18} \mathrm{O}$ values commonly exceeded $3.5 \%$ during the early Matuyama, whereas they only 


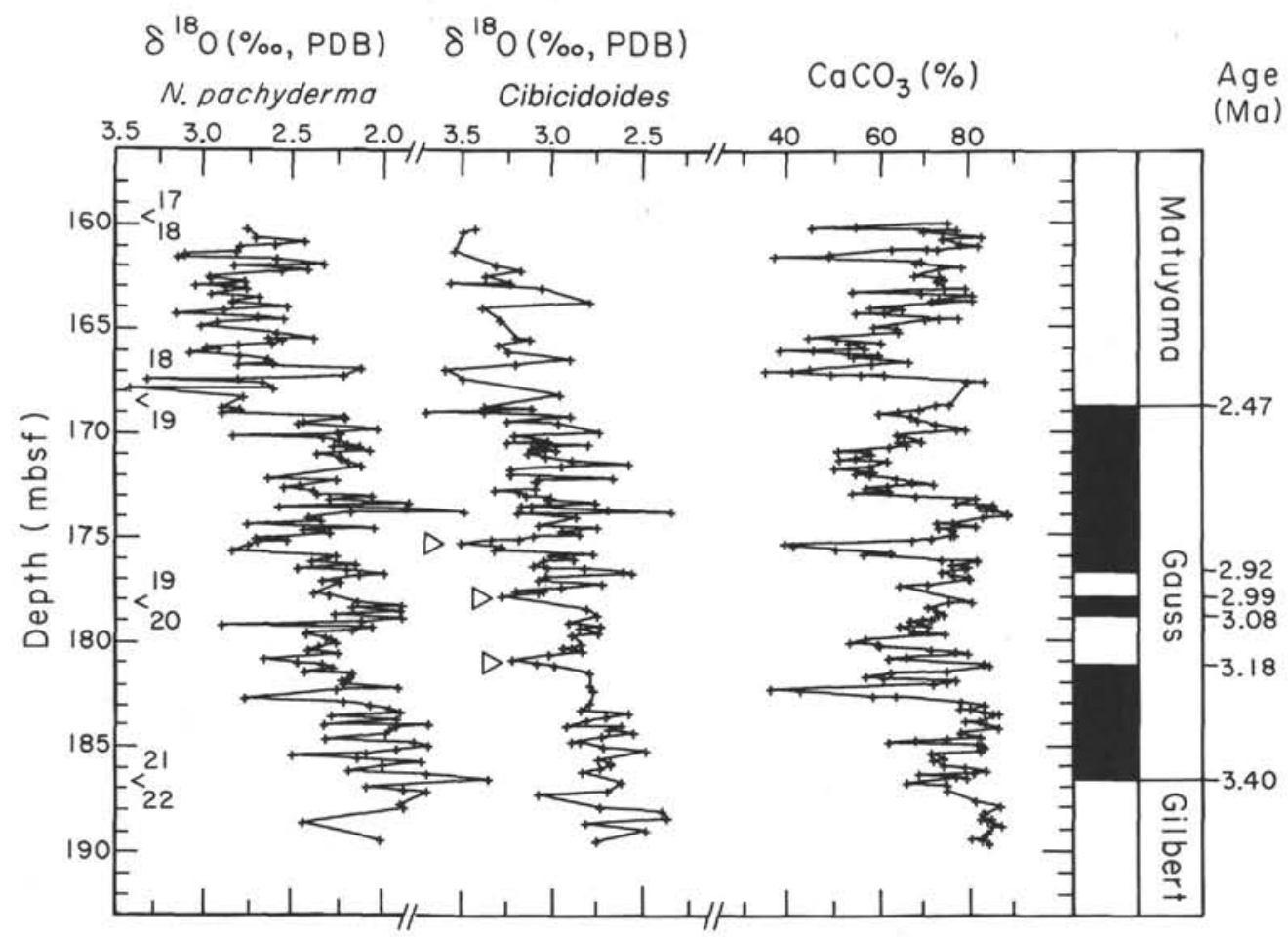

Figure 4. Oxygen isotopic results of planktonic ( $N$. pachyderma) and benthic (Cibicidoides) foraminifers and carbonate stratigraphy between 190 and $160 \mathrm{mbsf}$ in Hole 704A. Core breaks are numbered; glacial events are indicated in the benthic oxygen isotopic record by triangles. The abrupt changes that occurred across the Gauss/Matuyama boundary ( $2.47 \mathrm{Ma}$ ) include an increase in average planktonic $\delta^{18} \mathrm{O}$ values and an increase in the amplitude of the benthic $\delta^{18} \mathrm{O}$ signal.

exceeded this value once during the Gauss, at $2.85 \mathrm{Ma}$ (Fig. 4). The carbonate record did not change markedly at 168 mbsf, although sediments were generally lower in carbonate (i.e., higher in opal) during the Matuyama (average $42.7 \%$ ) than during the Gauss (72.7\%; Fig. 4).

At the Gauss/Matuyama boundary, benthic carbon isotopic values decreased by an average of $0.5 \%$ and remained offset during much of the Matuyama Chron (Fig. 5). In contrast, the planktonic $\delta^{13} \mathrm{C}$ signal showed no net change at $2.47 \mathrm{Ma}$ (Fig. 5 ). This resulted in an increase in the surface to deep gradient in $\delta^{13} \mathrm{C}$ values between planktonic and benthic foraminifers. In Figure 5 , the benthic and planktonic $\delta^{13} \mathrm{C}$ scales were offset from one another to avoid overlap during the Gilbert and Gauss Chrons, when $\delta^{13} \mathrm{C}$ values averaged $\sim 0.5 \% \circ-0.6 \%$ for both records. After $2.47 \mathrm{Ma}$, planktonic and benthic carbon isotopic values were naturally offset from one another largely because of the decrease in benthic $\delta^{13} \mathrm{C}$ values.

\section{0-130 mbsf}

Across the Gauss/Matuyama boundary, sedimentation rates increased abruptly by almost an order of magnitude in Hole 704A, resulting in a highly expanded early Matuyama interval (Fig. 3). Variations occurred in isotopic and carbonate composition of the sediments, and exceptionally large variations began at 150 mbsf (Fig. 6). Two distinct carbonate minima are centered at 149 and 142 mbsf. These events correspond to maxima in planktonic $\delta^{18} \mathrm{O}$ values, and the upper carbonate minimum (142 mbsf) corresponds to a maximum in benthic $\delta^{18} \mathrm{O}$ values. No benthic analyses could be obtained from the lower carbonate minimum (149 mbsf) because of the absence of Cibicidoides. The correlation between $\delta^{18} \mathrm{O}$ and percent carbonate suggests a typical "Atlantic-type" carbonate stratigraphy. The two carbonate minima correlate to two strong glacial events during the lower Matuyama, probably corresponding to isotopic stages 78 and 82 .

During the early Matuyama, the amplitude of the benthic $\delta^{13} \mathrm{C}$ signal is distinctly greater than the planktonic one (Fig. 7). The minima in benthic $\delta^{13} \mathrm{C}$ values correspond with maxima in the benthic $\delta^{18} \mathrm{O}$ record and minima in the carbonate record (Figs. 6 and 7). $A \sim 0.4 \%$ increase in average planktonic $\delta^{13} \mathrm{C}$ values at 139 mbsf is not observed in the benthic record.

\section{0-100 mbsf}

The interval from 130 to 100 mbsf is estimated to span $\sim 1.9$ to $1.7 \mathrm{Ma}$. The polarity reversal stratigraphy is ambiguous for this interval, with discrete sample measurements suggesting sporadic normal polarity between 128 and 89 mbsf. This interval probably represents all or part of the Olduvai Subchron, which suggests that the section is highly expanded. As a result of the paleomagnetic uncertainties, the polarity reversal stratigraphy is not plotted for this interval (Fig. 8).

Distinct glacial-interglacial cycles are recognizable throughout this interval where planktonic and benthic $\delta^{18} \mathrm{O}$ signals are generally covariant (Fig. 8), although the planktonic $\delta^{18} \mathrm{O}$ record exhibits higher frequencies than the benthic one. We hesitate to correlate isotopic events to the isotopic zonation of Raymo et al. (1989) until a higher resolution benthic $\delta^{18} \mathrm{O}$ record is obtained. The carbonate content is generally high between 126 and 102 mbsf (2.2-1.9 Ma) with the exception of a double-spiked minimum between 115 and 112 mbsf (Fig. 6). This carbonate low coincides with a pronounced maxima in planktonic and benthic $\delta^{18} \mathrm{O}$ values indicating a strong glacial event (stage 70 ) and typical Atlantic-type carbonate stratigraphy. Benthic carbon isotopic ratios show high-amplitude variations throughout this interval 


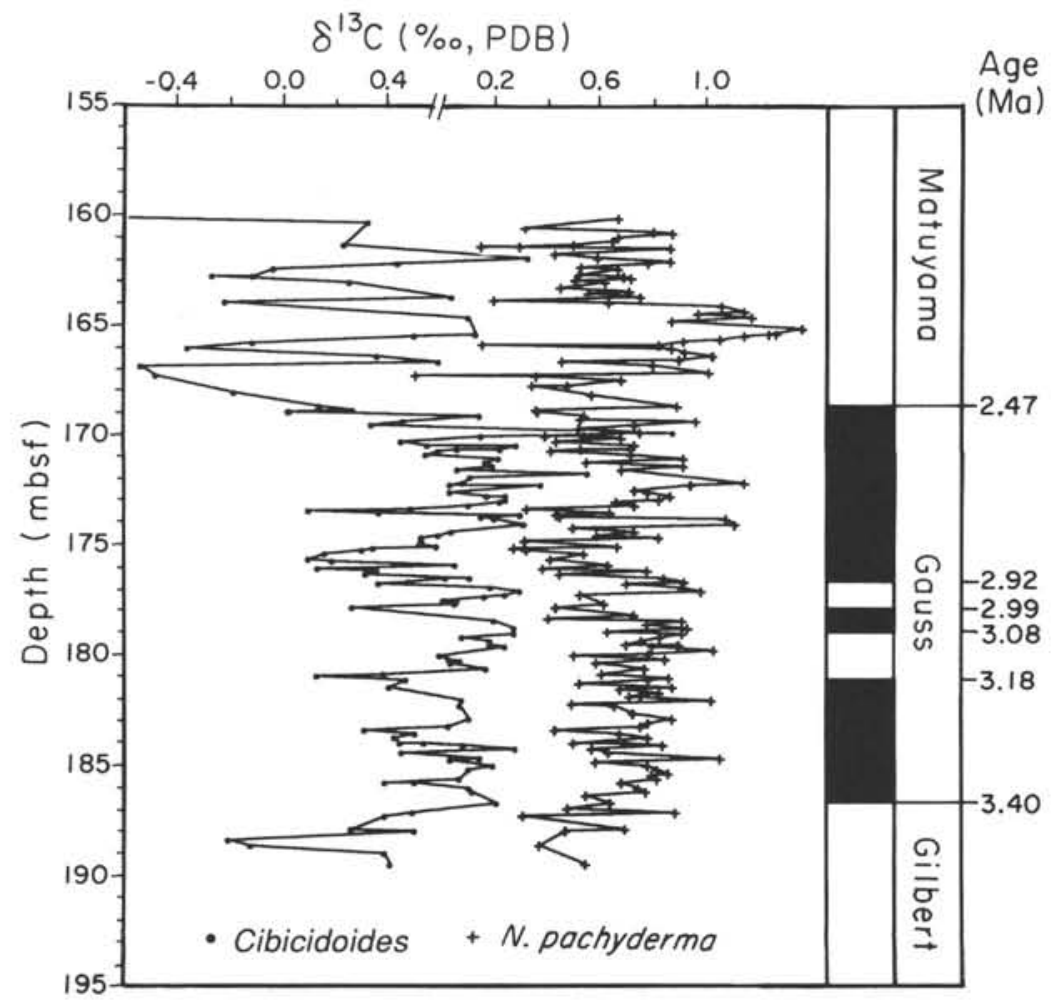

Figure 5. Carbon isotopic results of planktonic ( $N$. pachyderma) and benthic (Cibicidoides) foraminifers between 190 and 160 mbsf in Hole 704A. Benthic $\delta^{13} \mathrm{C}$ values decrease at the Gauss/Matuyama boundary.

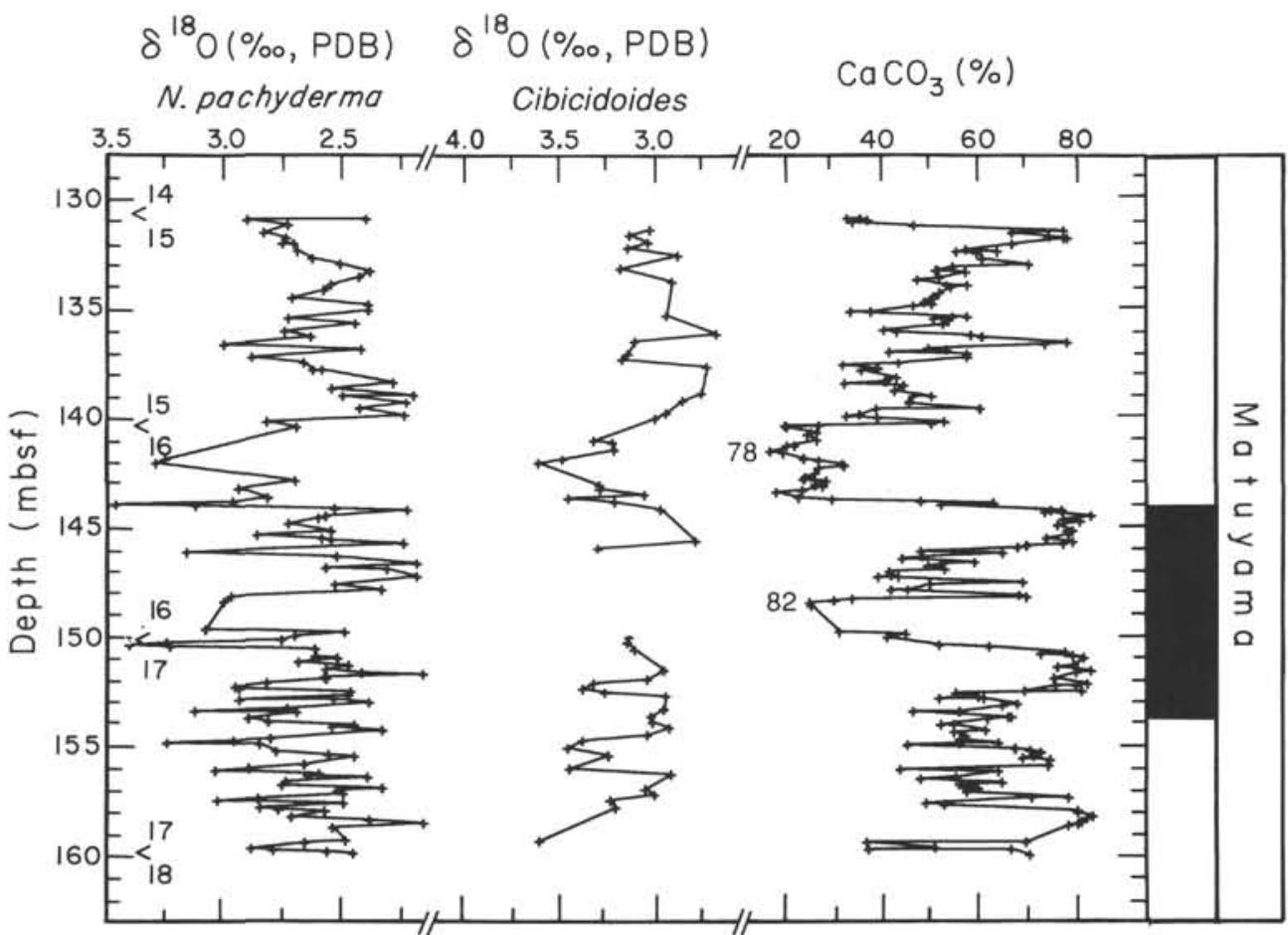

Figure 6. Oxygen isotopic results of planktonic ( $N$. pachyderma) and benthic (Cibicidoides) foraminifers and carbonate stratigraphy between 160 and 130 mbsf in Hole 704A. Core breaks are numbered. The strong minima in $\% \mathrm{CaCO}_{3}$ centered at 149 and 142 mbsf probably correspond to isotopic stages 82 and 78 , respectively. 


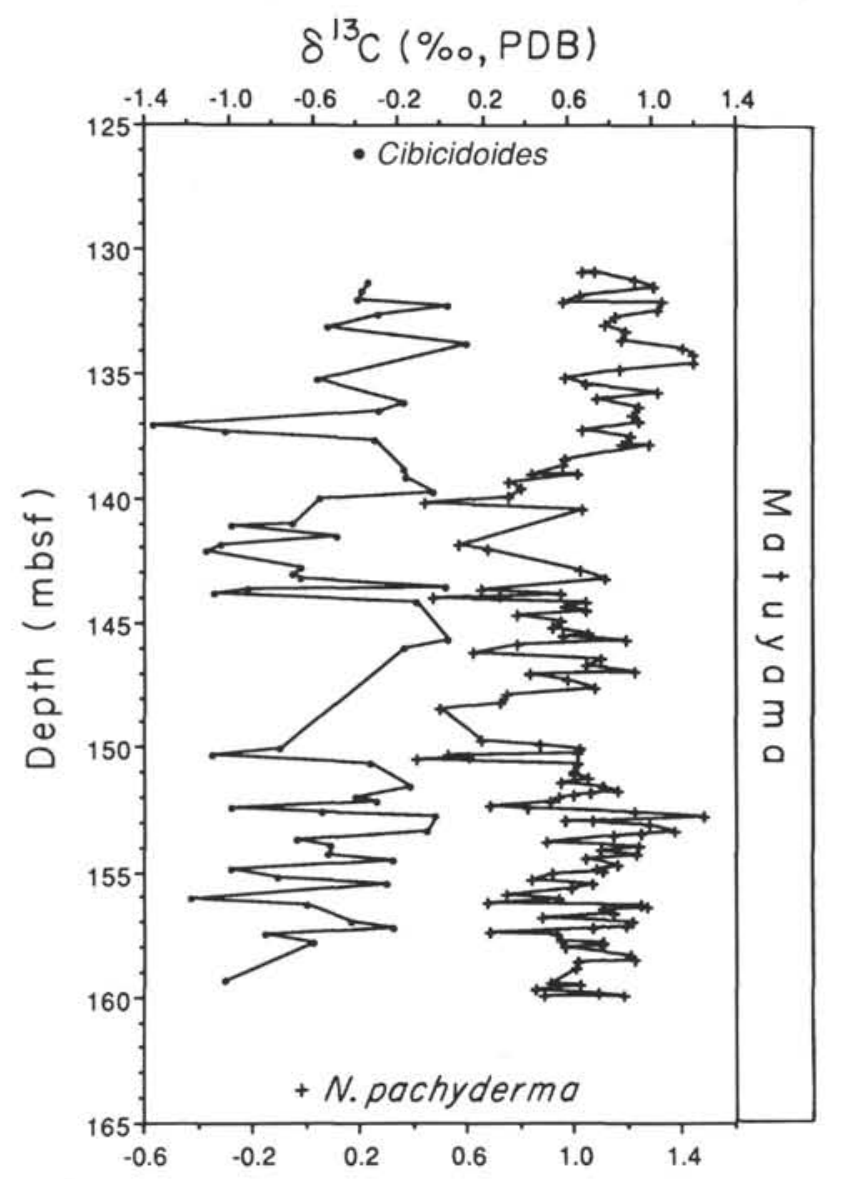

Figure 7. Carbon isotopic results of planktonic (N. pachyderma) and benthic (Cibicidoides) foraminifers between 160 and $130 \mathrm{mbsf}$ in Hole $704 \mathrm{~A}$. The minima in benthic $\delta^{13} \mathrm{C}$ values correspond with maxima in the $\delta^{18} \mathrm{O}$ record (Fig. 6).

with $\delta^{13} \mathrm{C}$ minima corresponding to $\delta^{18} \mathrm{O}$ maxima (i.e., glacial events; Fig. 9).

\section{0-70 mbsf}

This section is estimated to span the time interval between $\sim 1.7$ and 1.4 Ma (Fig. 10). The top of the Olduvai Subchron has been placed at 87.4 mbsf by Hailwood and Clement (this volume). Planktonic and benthic $\delta^{18} \mathrm{O}$ variations are generally covariant with the long depth spacing of the glacial-interglacial fluctuations, suggesting a high sedimentation rate for this interval. The carbonate content is relatively low between 100 and 80 mbsf with the exception of a distinct maximum at 85 mbsf (probably stage 59). The increase in carbonate content at 80 mbsf $(\sim 1.5 \mathrm{Ma}$; Fig. 10) is coincident with an increase in planktonic and benthic $\delta^{18} \mathrm{O}$ values. The planktonic and benthic $\delta^{13} \mathrm{C}$ records are generally parallel during this interval with a distinct increase at 80 mbsf (Fig. 11), coinciding with increased carbonate content (Fig. 10).

\section{0-40 mbsf}

The interval from 70 to 40 mbsf extends from $\sim 1.4$ to 1.0 $\mathrm{Ma}$, based on tentative correlation to the oxygen isotopic zonation of Ruddiman et al. (1989). Beginning at 70 mbsf $(\sim 1.4 \mathrm{Ma})$, all parameters exhibit a series of high-frequency fluctuations that are highly correlated with one another (Fig. 12). Planktonic and benthic $\delta^{18} \mathrm{O}$ signals are covariant and are inversely correlated with carbonate fluctuations. Oxygen isotopic maxima (i.e., glacial events) correspond to carbonate minima (opal maxima), which is typical of an Atlantic-type carbonate stratigraphy.

Between 70 and 40 mbsf, planktonic and benthic $\delta^{13} \mathrm{C}$ variations are positively correlated (Fig. 13), although the amplitude of the benthic signal is greater than the planktonic one. Carbon isotopic fluctuations are inversely correlated with oxygen isotopic variations (Figs. 12 and 13) such that glacial intervals are marked by minima in $\delta^{13} \mathrm{C}$ values.

\section{DISCUSSION}

\section{Gauss Chron (3.4-2.47 Ma)}

At DSDP Site 606, Keigwin (1986) identified brief maxima in benthic $\delta^{18} \mathrm{O}$ during the late Gauss at $3.1,2.7$, and $2.6 \mathrm{Ma}$ and interpreted them as temperature and/or ice volume events that preceded the major intensification of Northern Hemisphere glaciation at 2.4 Ma. Curry and Miller (1990) also found at least two $\delta^{18} \mathrm{O}$ enrichments prior to the increase at $2.4 \mathrm{Ma}$. In Hole $704 \mathrm{~A}$, three prominent benthic $\delta^{18} \mathrm{O}$ maxima occurred at 3.16, 3.0, and 2.88 Ma during the Gauss (Fig. 4), but further refinement of the chronology is needed before these events can be correlated with other records.

Ciesielski and Grinstead (1986) identified the latest Gauss $(2.68-2.47 \mathrm{Ma})$ as the time of greatest change in Neogene climate in the northern antarctic and subantarctic regions. At Site 514 in the western subantarctic South Atlantic, the latest Gauss was marked by several northward advances of the PFZ (maximum advances at 2.86, 2.79, 2.67, and 2.58-2.47 Ma), as recorded by changes in radiolarian assemblages (Ciesielski and Grinstead, 1986). Accumulation of ice-rafted detritus was also high during the late Gauss, with a maximum accumulation of $200 \mathrm{mg} / \mathrm{cm}^{2} / 10^{3} \mathrm{yr}$ at $\sim 2.67 \mathrm{Ma}$ (Bornhold, 1983). From this evidence, Ciesielski and Grinstead (1986) concluded that major latest Gauss climatic cooling in the Southern Ocean preceded the first glacial maximum in the North Atlantic at 2.37 Ma (Shackleton et al., 1984).

Sites $704\left(47^{\circ} \mathrm{S}\right)$ and $514\left(46^{\circ} \mathrm{S}\right)$ are at similar latitudes, and the chronologies of both sites are based on magnetostratigraphy. At Site 704, the most abrupt changes in isotopic and sedimentologic parameters did not occur in the late Gauss, but rather occurred at the Gauss/Matuyama boundary at $2.47 \mathrm{Ma}$ (Fig. 4). This suggests that either the latest Gauss is missing in Hole 704A or migrations of the PFZ occurred earlier in the western subantarctic South Atlantic than in the east. The latter hypothesis requires further testing by direct correlation of changes in diatom and radiolarian assemblages between these sites and by refinement of the isotope chronology at Site 704. It is likely that several hundreds of thousands of years of the late Gauss are missing at the break between Cores 114-704A-18X and 114-704A-19X.

\section{Gauss/Matuyama Boundary (2.47 Ma)}

Across the Gauss/Matuyama boundary, several important changes occurred in the sedimentologic and isotopic parameters of Hole 704A. Sedimentation rates increased markedly from 18 $\mathrm{m} / \mathrm{m}$.y. in the late Gauss to $100 \mathrm{~m} / \mathrm{m} . \mathrm{y}$. in the early Matuyama (Fig. 3). This represents almost an order of magnitude increase in the flux of biogenic material to the sediments (Froelich et al., this volume). Although the proportion of opal to carbonate did not change abruptly at the Gauss/Matuyama boundary (Fig. 4), average percentages of biogenic silica were greater during the Matuyama than during the Gauss (Froelich et al., this volume). This increase in biogenic accumulation rates at $2.47 \mathrm{Ma}$ is interpreted as reflecting increased productivity of surface waters as the PFZ migrated near Site 704.

At $2.47 \mathrm{Ma}$, planktonic $\delta^{18} \mathrm{O}$ values increased by an average of $0.5 \%$ (Fig. 4). The planktonic $\delta^{18} \mathrm{O}$ record is controlled 


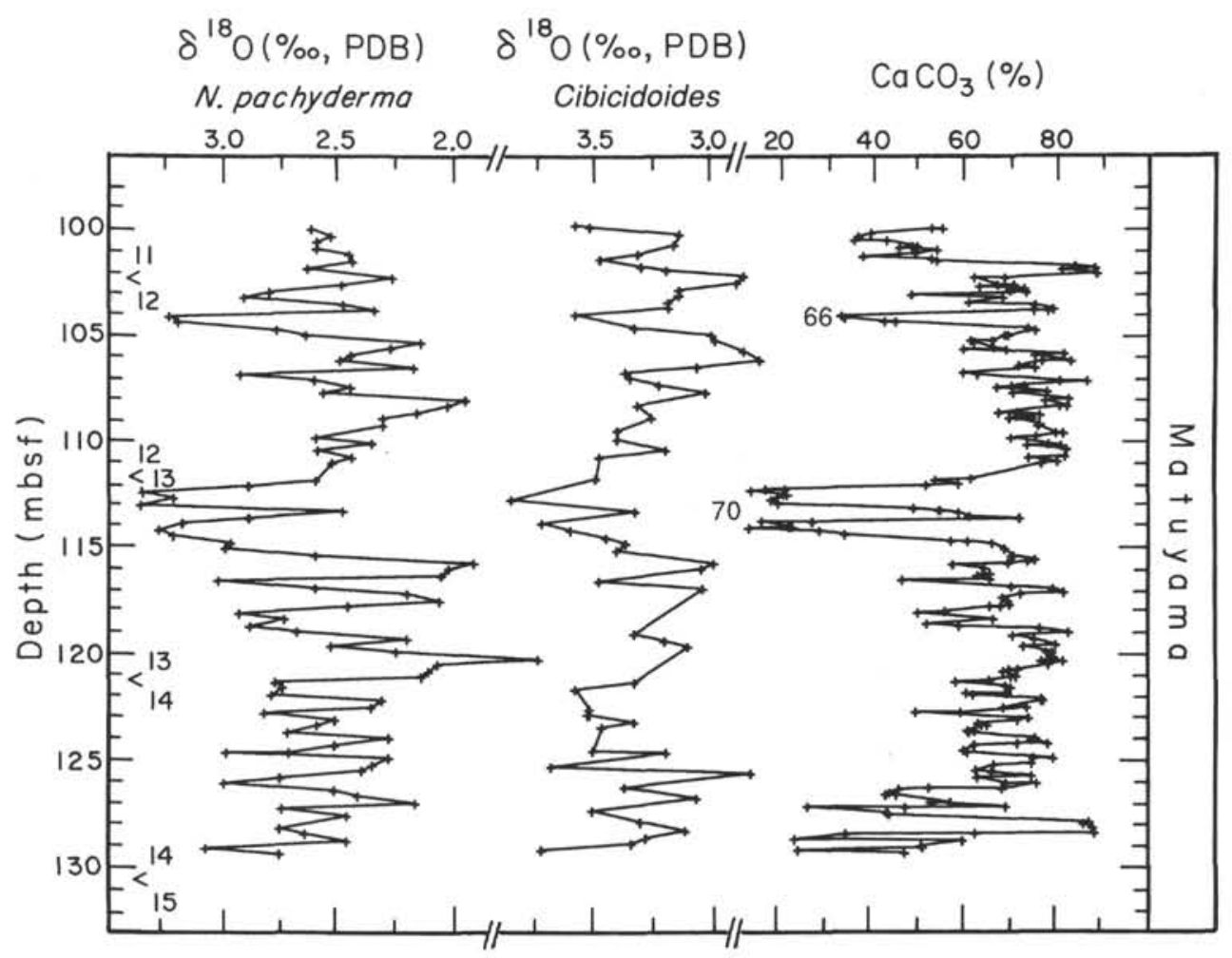

Figure 8. Oxygen isotopic results of planktonic ( $N$. pachyderma) and benthic (Cibicidoides) foraminifers and carbonate stratigraphy between 130 and 100 mbsf in Hole 704A. Core breaks are numbered. The interval is estimated to span 1.9 to $1.7 \mathrm{Ma}$ within the early Matuyama Chron.

both by temperature changes associated with migrations of sea surface isotherms and compositional changes in the $\delta^{18} \mathrm{O}$ of seawater from variations in global ice volume. In the modern South Atlantic, the $\delta^{18} \mathrm{O}$ of Neogloboquadrina pachyderma from core tops increases by $3 \%$ o between $41^{\circ}$ and $60^{\circ} \mathrm{S}$, reflecting the large temperature gradients associated with the PFZ (Charles and Fairbanks, 1990). As a result, any translation in the frontal boundary of the PFZ will produce measurable changes in the planktonic $\delta^{18} \mathrm{O}$ record. The increase in planktonic $\delta^{18} \mathrm{O}$ values across the Gauss/Matuyama boundary, therefore, reflects both a northward advance of the PFZ and an increase in global ice volume. Faunal data also indicate a northward shift of Antarctic microfossil assemblages in the South Atlantic sector of the Southern Ocean at $2.47 \mathrm{Ma}$ (Ciesielski and Grinstead, 1986; Abelman and Gersonde, 1990).

Across the Gauss/Matuyama boundary, the amplitude of the benthic $\delta^{18} \mathrm{O}$ signal increased, indicating greater intensity of glacial-interglacial cycles (Fig. 4). Raymo et al. (1989) reported an increase in glacial intensity between 2.4 and 2.3 $\mathrm{Ma}$, when the ice volume signal increased to about two-thirds that of the late Pleistocene. At Site 607, this event consists of three prominent $\delta^{18} \mathrm{O}$ maxima designated as stages 100,98 , and 96. These stages are probably absent at Hole 704A because of a hiatus or nonrecovery in the gap between Cores 114-704A-18X and 114-704A-19X. Future sampling and isotopic analysis of Hole 704B within this interval may reveal whether these important isotopic stages are present.

At Hole $704 \mathrm{~A}$, the climatic transition at $2.47 \mathrm{Ma}$ is also marked by an increase in the accumulation of ice-rafted detritus (Warnke and Allen, this volume). This increase probably reflects both an increase in the delivery of ice-rafted debris from the glacial erosion of Antarctica (Warnke and Allen, this volume) and a migration of the northern boundary of the PFZ. Because the rate of melting of tabular icebergs increases at the Subantarctic Front, an increase in the accumulation of ice-rafted detritus is expected as the Subantarctic Front migrated closer to Site 704.

An important problem in investigating the late Pliocene climate is the relative fraction of the ice growth on Antarctica vs. the Northern Hemisphere at 2.4 Ma. Warnke and Allen (this volume) interpreted the increase in ice-rafted detritus accumulation at $2.47 \mathrm{Ma}$ as representing the marine equivalent of the Sirius till. They suggested that this event marked the beginning of the delivery of voluminous ice-rafted detritus to the Southern Ocean by large, wet-based continental ice sheets. This major increase in the size of the Antarctic ice sheet may have been responsible for the overriding of the Transantarctic Mountains (Mayewski, 1975; Denton et al., 1984; Prentice et al., 1986). If the increase in ice-rafted detritus is interpreted to represent an Antarctic ice volume increase, then the global increase found in planktonic and benthic $\delta^{18} \mathrm{O}$ signals over the Gauss/Matuyama boundary must reflect ice growth in both the Northern and Southern hemispheres.

In the North Atlantic, the inception of ice-rafted sediment is diachronous with latitude. In the Norwegian Sea, the first large pulse of ice-rafted detritus and the onset of repetitive glacial events began at $2.56 \mathrm{Ma}$ (Jansen et al., 1990); Farther south at Sites 607,609 , and 552, only minor amounts of ice-rafted detritus are found before $2.4 \mathrm{Ma}$ (Raymo et al., 1989), and the first major pulse of ice-rafted detritus occurred at $2.4 \mathrm{Ma}$ (stage 100). If the chronology in Hole $704 \mathrm{~A}$ is correct, increased accumulation of ice-rafted detritus appears to have been synchronous between the subantarctic and the open North Atlantic.

One hypothesis proposes that Antarctic ice sheets reached their maximum configuration during the late Gauss and were unable to expand further because they had reached sea level 


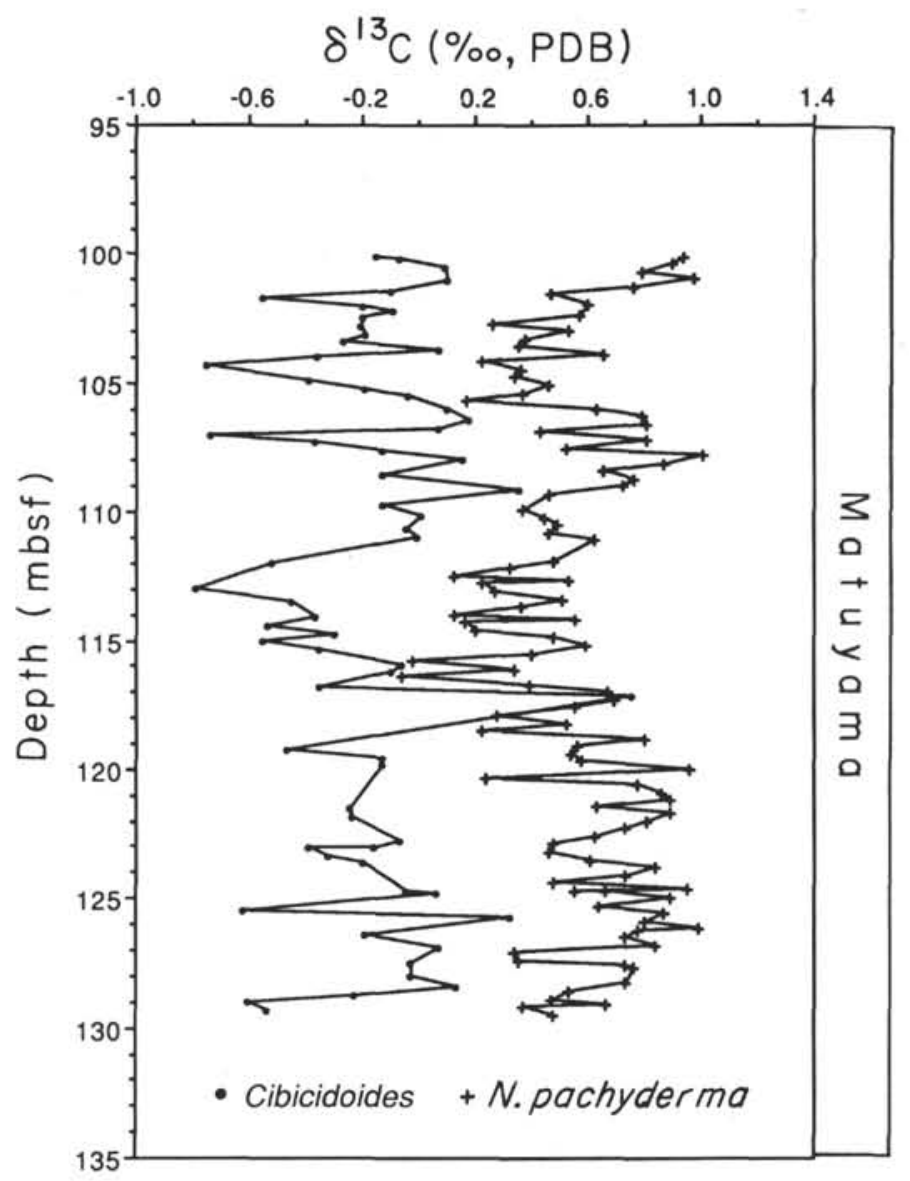

Figure 9. Carbon isotopic results of planktonic (N. pachyderma) and benthic (Cibicidoides) foraminifers between 130 and $100 \mathrm{mbsf}$ in Hole 704A.

(Ciesielski and Grinstead, 1986). With the expansion of ice sheets in the Northern Hemisphere, sea level was gradually lowered and allowed ice advance in the Southern Hemisphere along the Antarctic marine margins and interior thickening because of decreased drawdown (Ciesielski and Grinstead, 1986). Thus, Northern and Southern hemisphere ice volumes were coupled and fueled by interhemispheric feedback through sea level (Ciesielski and Grinstead, 1986). Future correlation of oxygen isotopic chronologies between Sites 607 and 704 will allow us to evaluate the relative timing of ice-rafting history between the polar oceans and to determine if lead or lag relationships exist between the hemispheres over the Gauss/Matuyama boundary.

Another pronounced change that occurred at $2.47 \mathrm{Ma}$ was an abrupt decrease in benthic $\delta^{13} \mathrm{C}$ values by $0.5 \%$ (Fig. 4). Unlike the benthic record, carbon isotopic values of $N$. pachyderma showed no change at 2.47 Ma (Fig. 4). As a result, the carbon isotopic gradient between benthic and planktonic foraminifers increased markedly after $2.47 \mathrm{Ma}$. Surprisingly, the $\delta^{13} \mathrm{C}$ of fine-fraction carbonate (assumed to be mostly coccolithophorids) also decreased by $\sim 1.5 \%$ across the Gauss/Matuyama boundary, which is similar to the benthic signal but unlike the planktonic foraminiferal record (Mead et al., this volume).

Because both coccolithophorids and planktonic foraminifers inhabit surface water, it is perplexing as to why finefraction $\delta^{13} \mathrm{C}$ should decrease and that of planktonic foraminifers should not. The increase in the accumulation rates of carbonate and silica across the Gauss/Matuyama boundary points to an increase in upwelling and productivity as the PFZ migrated over Site 704 . Increased upwelling of ${ }^{13} \mathrm{C}$-depleted carbon from deep waters would be expected to decrease the $\delta^{13} \mathrm{C}$ of the surface water carbon pool and should be reflected by both coccoliths and planktonic foraminifers. In Holocene sediments underlying regions of upwelling, an inverse relationship has been reported between the $\delta^{13} \mathrm{C}$ of nannofossils and foraminifers (Goodney et al., 1980). Data from core tops show a large negative excursion in coccolith $\delta^{13} \mathrm{C}$ values, whereas a positive excursion occurs in the $\delta^{13} \mathrm{C}$ of planktonic foraminifers between $10^{\circ}$ and $18^{\circ} \mathrm{S}$ in the tropical Indian Ocean. High rates of primary productivity may antithetically effect the carbon isotopic disequilibrium of carbonate-secreting phytoplankton and zooplankton, perhaps due to the influence of upwelling on growth and metabolic rate ("vital effects"). Alternatively, $N$. pachyderma may live deeper in the water column than coccolithophorids and sample a different dissolved carbon pool (see Mead et al., this volume, for more complete discussion of this topic). The apparent divergence in the planktonic foraminiferal and fine-fraction $\delta^{13} \mathrm{C}$ signals over the Gauss/Matuyama boundary remains enigmatic.

We assume that the decrease in benthic $\delta^{13} \mathrm{C}$ values at 2.5 Ma represents a decrease in the average $\delta^{13} \mathrm{C}$ of the $\Sigma \mathrm{CO}_{2}$ of deep waters at Site 704. Today Site 704 is positioned at a water depth of $2532 \mathrm{~m}$ in a mixing zone between NCW (temperature $=2.5^{\circ} \mathrm{C}$, salinity $=34.94 \%, \delta^{13} \mathrm{C}=1.08 \%$ ) and CPDW (temperature $=0.62^{\circ} \mathrm{C}$, salinity $=34.71 \%$, $\delta^{13} \mathrm{C}=0.43 \%$ ) 


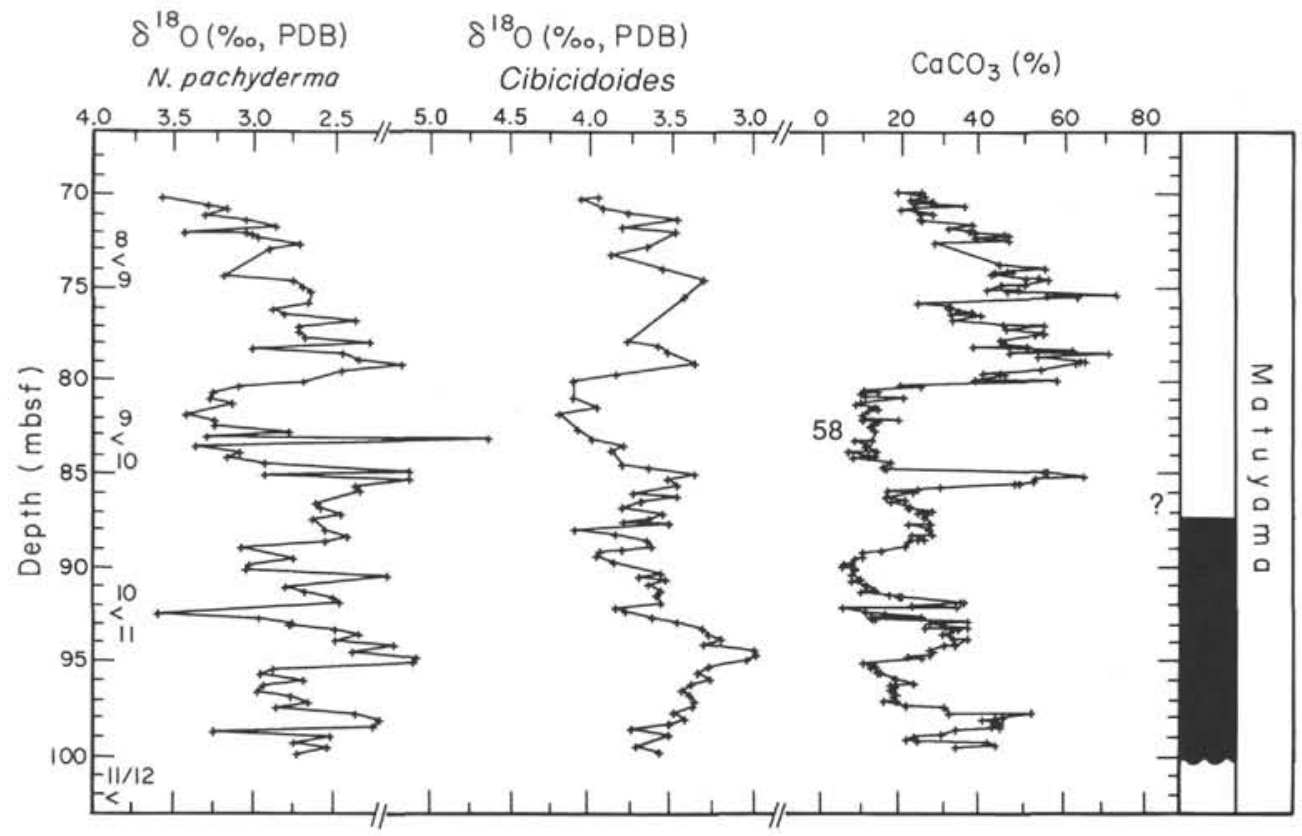

Figure 10. Oxygen isotopic results of planktonic ( $N$. pachyderma) and benthic (Cibicidoides) foraminifers and carbonate stratigraphy between 100 and $70 \mathrm{mbsf}$ in Hole 704A. Core breaks are numbered. The interval from 100 to $80 \mathrm{mbsf}(\sim 1.7-1.5 \mathrm{Ma})$ is marked by relatively low carbonate (and high opal) values.

(Fig. 2). The decrease in benthic $\delta^{13} \mathrm{C}$ values at $2.47 \mathrm{Ma}$ indicates that the ventilation rate of deep waters at Site 704 was reduced, and that deep waters were generally more nutrient enriched and oxygen depleted during the Matuyama than during the Gauss.

There are several alternative interpretations for the observed benthic $\delta^{13} \mathrm{C}$ decrease at the Gauss/Matuyama boundary. First, an increase in productivity of the Southern Ocean could have increased the rain rate of organic carbon to the deep sea, and oxidation of this isotopically depleted carbon would have led to a decrease in $\delta^{13} \mathrm{C}$ values of CPDW. The increase in sediment-accumulation rates in Hole 704A supports high productivity beginning at $2.47 \mathrm{Ma}$. Increased productivity and carbon pumping from surface to deep water is expected to be recorded by an increase in the surface to deep $\delta^{13} \mathrm{C}$ gradient. An increase in the ${ }^{13} \mathrm{C}$ gradient is observed between planktonic and benthic foraminifers at 2.47 Ma (Fig. 4), but is not apparent between the fine fraction (i.e., coccoliths) and benthic foraminifers, yielding disparate results.

An alternative, and preferred, interpretation is that the decrease in benthic $\delta^{13} \mathrm{C}$ values reflects a change in the relative mixing ratio of NCW and CPDW. Oppo and Fairbanks (1987) proposed that the relative flux of NCW could be monitored by $\delta^{13} \mathrm{C}$ changes in the Southern Ocean, where the high $\delta^{13} \mathrm{C}$ of NCW $\left(\sim 1 \%\right.$ ) mixes with the low $\delta^{13} \mathrm{C}$ of CPDW $(\sim 0.4 \%$ o). Site 704 occupies an ideal position from which to monitor the relative fluxes of these water masses (Fig. 2).

To examine this problem, we compared $\delta^{13} \mathrm{C}$ records (corrected to Planulina wuellerstorfi) from Southern Ocean Site 704, North Atlantic Hole 552A, and Pacific Core V28-179 (Fig. 14). Today, a $1 \%$ to $1.5 \%$ gradient in $\delta^{13} \mathrm{C}$ between the Atlantic and Pacific reflects the progressive oxidation of organic carbon (depleted in ${ }^{13} \mathrm{C}$ by some $25 \%$ ) as deep water flows from the North Atlantic via the Circumpolar Current toward the North Pacific. The Southern Ocean $\delta^{13} \mathrm{C}$ values are intermediate between the North Atlantic and Pacific, re- flecting the contribution of recirculated Pacific Deep Water and NCW.

Prior to $2.47 \mathrm{Ma}$, a $\delta^{13} \mathrm{C}$ gradient similar to the modern one existed between the North Atlantic, Southern Ocean, and Pacific (Fig. 14). The North Atlantic had the highest $\delta^{13} \mathrm{C}$ values, the Southern Ocean had intermediate values, and the Pacific had the lowest values. After $2.4 \mathrm{Ma}$, Southern Ocean $\delta^{13} \mathrm{C}$ values at Site 704 decreased abruptly and approached those of Pacific Core V28-179 (Fig. 14).

The shift in benthic $\delta^{13} \mathrm{C}$ values at Site 704 at $2.47 \mathrm{Ma}$ suggests that the deep waters of the southeast Atlantic became more like those in the Pacific in their chemistry. This could result from changing the mixing ratios between NCW and CPDW at Site 704 either by reducing the relative production rate of NCW or by increasing the relative flux of CPDW. To a great extent, the position of the NCW/CPDW mixing zone in the subantarctic South Atlantic is controlled by the position of the Antarctic Circumpolar Current and the PFZ. With progressive cooling and rapid northward migration of the PFZ at $2.47 \mathrm{Ma}$, the mixing zone between NCW and CPDW may have moved north causing $\delta^{13} \mathrm{C}$ values to decrease toward the Pacific end member. However, moving this interface north by $10^{\circ}$ of latitude today would only result in a $\sim 0.3 \%$ decrease in $\delta^{13} \mathrm{C}$, suggesting that this process cannot account for the total benthic $\delta^{13} \mathrm{C}$ shift observed at the Gauss/Matuyama boundary.

We prefer the interpretation that the contribution of NCW to the Southern Ocean was reduced at $2.47 \mathrm{Ma}$ or that the chemical characteristics of NCW were altered at this time. At 2.47 Ma, the $\delta^{13} \mathrm{C}$ gradient between the Southern Ocean and Pacific decreased, but the North Atlantic/Pacific $\delta^{13} \mathrm{C}$ gradient remained the same (Fig. 14). The consistently high benthic $\delta^{13} \mathrm{C}$ values at Site 552 in the North Atlantic suggest that NCW was being produced during the Matuyama (Shackleton et al., 1984), but the rate of production may have been less than today and its penetration into the Atlantic and Southern Ocean was weakened (Raymo et al., 1990). 
Other studies also point to reduced rates of NCW production during the Matuyama relative to the Gauss. Jansen et al. (1988) found that sediments of the Norwegian Sea were dominated by extreme carbonate dissolution during much of the Matuyama. The calcite dissolution was interpreted as the result of high bottom water $\mathrm{CO}_{2}$ suggesting sluggish deepwater ventilation rates of the Norwegian-Greenland Sea during the Matuyama (Jansen et al., 1988). In the eastern Atlantic Hole 655A (4746 m), Curry and Miller (1990) found lowered benthic $\delta^{13} \mathrm{C}$ values and increased preservation of organic matter during enriched ${ }^{18} \mathrm{O}$ intervals of the late Pliocene. They concluded that the equatorial Atlantic Ocean was dominated in the Pliocene by deep water that originated in the Southern Ocean and had chemical properties similar to those of deep waters in the Pacific Ocean. Raymo et al. (1990) reached similar conclusions by comparison of Atlantic/Pacific $\delta^{13} \mathrm{C}$ gradients over the past $2.5 \mathrm{Ma}$. These results are consistent with the carbon isotopic data from Site 704, suggesting that NCW production was suppressed and that the ventilation rate of the deep Atlantic was reduced during glacial intervals of the late Pliocene after $2.5 \mathrm{Ma}$.

\section{Early Matuyama (2.47-1.4 Ma)}

Two prominent glacial events are apparent in the early Matuyama of Hole $704 \mathrm{~A}$ at 149 and 142 mbsf. These events are marked by maxima in $\delta^{18} \mathrm{O}$ values, minima in carbonate, and maxima in opal content of the sediments (Froelich et al., this volume). The two events correlate to isotopic stages 82

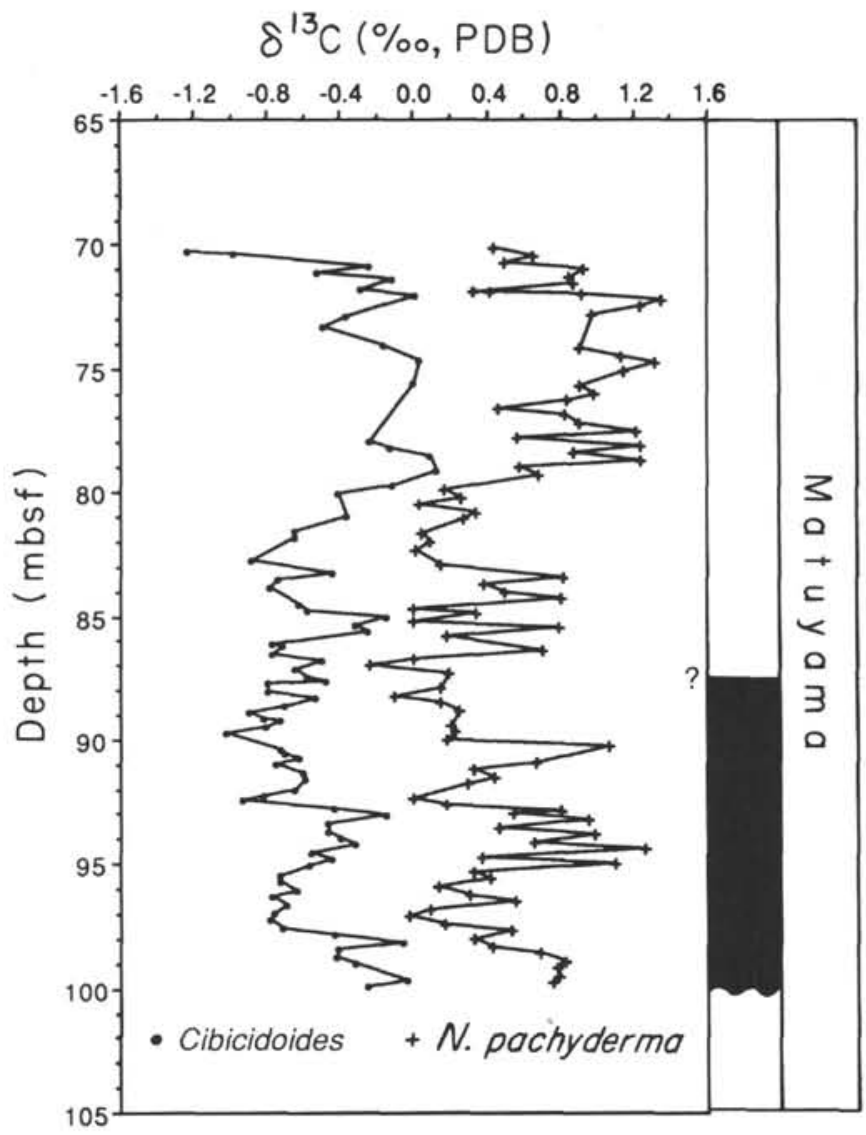

Figure 11. Carbon isotopic results of planktonic (N. pachyderma) and benthic (Cibicidoides) foraminifers between 100 and 70 mbsf in Hole $704 \mathrm{~A}$. and 78, which represent strong glacial events dated at 2.027 and 1.941, respectively (Raymo et al., 1989). Support for this correlation comes from identification of a normal polarity event between 153.5 and 144 mbsf in the shipboard whole-core magnetic data of Hole 704A (Hailwood and Clement, this volume). Assuming that this represents the Réunion Event, with age boundaries of 2.04 and $2.01 \mathrm{Ma}$, isotopic stages 82 and 78 fit well into this chronology. The carbonate and opal data suggest that the PFZ moved to the north of Site 704 during these prominent glacial events of the early Matuyama.

Between $\sim 1.9$ and $1.7 \mathrm{Ma}(140-105 \mathrm{mbsf})$, the PFZ occupied a southerly position relative to Site 704 , as indicated by the persistently high carbonate content (low opal) (Fig. 8). Two exceptions were brief northerly advances of the PFZ, which are marked by low carbonate values at 130-127 and 117-114 mbsf. These events probably correspond to strong glacial episodes associated with isotopic stages $74(1.862 \mathrm{Ma})$ and $70(1.782 \mathrm{Ma})$, respectively.

At $\sim 1.7 \mathrm{Ma}$ (102 to $98 \mathrm{mbsf}$; Fig. 10), the PFZ migrated north again, as evidenced by decreasing carbonate and increasing biogenic silica in the sediments (Froelich et al., this volume) and by the increased abundance of diatoms that indicate upwelling (Fenner, this volume). The interval between 1.65 and $1.52 \mathrm{Ma}$ (98 and $80 \mathrm{mbsf}$ ) represents a time when the PFZ occupied a prolonged northerly position and the southern boundary of the PFZ (i.e., the Antarctic Front) was nearest to Hole 704A. Common to dominant occurrences of the diatom Thalassiosira nitzschoides throughout this interval indicate upwelling conditions within the PFZ (Fenner, this volume).

The abundance of ice-rafted detritus decreased abruptly at 1.65 Ma (98 mbsf; Warnke and Allen, this volume), which may indicate that the zone of most rapid melting of icebergs was located north of Site 704. Alternatively, Warnke and Allen (this volume) suggested that the low abundance of ice-rafted debris in sediments younger than $1.65 \mathrm{Ma}$ was caused by a changed in the style of glaciation on Antarctica from "wetbased" ice sheets in the early Matuyama (2.47-1.65 Ma) to "dry-based" conditions during the late Matuyama (1.56-0.98 Ma). They proposed that modern polar conditions developed at this time and that Antarctica became a desert with large polar ice sheets that have little erosive power.

\section{Late Matuyama (1.4-1.1 Ma)}

Beginning at $\sim 1.4 \mathrm{Ma}$ (70 mbsf), all isotopic and sedimentologic parameters begin to respond in a regular cyclical fashion (Figs. 12 and 13). Planktonic and benthic $\delta^{18} \mathrm{O}$ signals covary and correspond with carbonate/silica fluctuations with a typical Atlantic-type correlation (Fig. 12). Planktonic and benthic carbon isotopes also covary such that minima in $\delta^{13} \mathrm{C}$ correspond with $\delta^{18} \mathrm{O}$ maxima (Fig. 13). This is typical of the pattern observed in the late Pleistocene of the Southern Ocean (Charles and Fairbanks, 1990).

It is intriguing why such a tightly coupled correlation between the Northern and Southern hemispheres developed at $1.4 \mathrm{Ma}$ and not previously. One possibility is that the PFZ reached a critical position in the subantarctic South Atlantic from which glacial advances brought the PFZ north of Site 704 and interglacial retreats moved it south of $47^{\circ} \mathrm{S}$. Prior to this time, the PFZ may have exhibited less variability in its position, maintaining a position of longer duration either north or south of Site 704 . As a result, the surface water signal was damped. Alternatively, the intensity of glacial-interglacial cycles and translation of the PFZ may have increased at $\sim 1.4$ $\mathrm{Ma}$, but no increase in amplitude is observed in the oxygen isotopic record of Site 607 in the North Atlantic at this time (Ruddiman et al., 1989). 


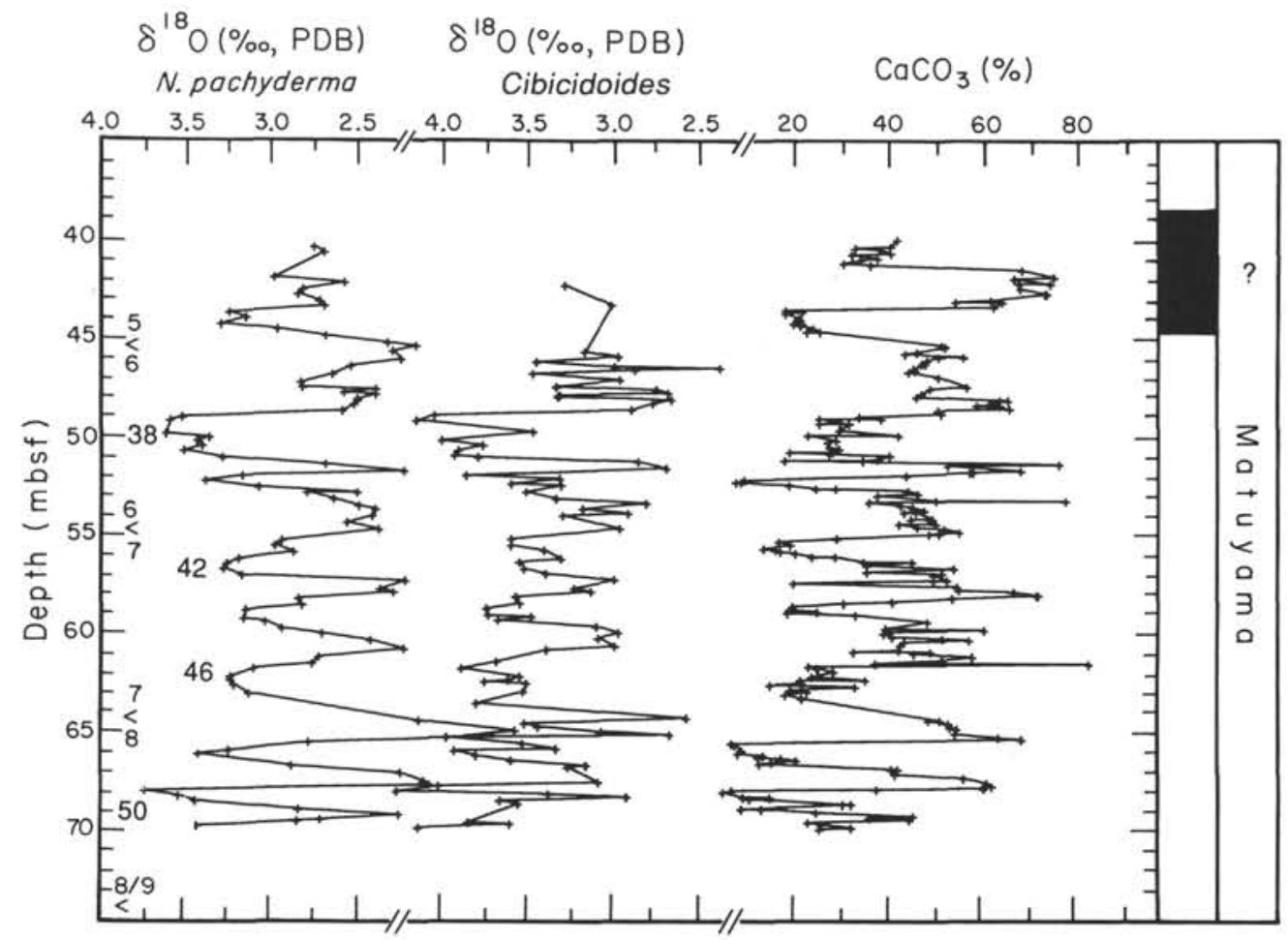

Figure 12. Oxygen isotopic results of planktonic ( $N$. pachyderma) and benthic (Cibicidoides) foraminifers and carbonate stratigraphy between 70 and $40 \mathrm{mbsf}$ in Hole $704 \mathrm{~A}(1.4$ to $1.0 \mathrm{Ma})$. Core breaks are numbered. Note the high inverse correlation between planktonic and benthic $\delta^{18} \mathrm{O}$ and $\% \mathrm{CaCO}_{3}$. Low carbonate during glacial events is typical of an Atlantic-type carbonate stratigraphy.

Raymo et al. (1990) suggested that glacial suppression of North Atlantic Deep Water (NADW) intensified after 1.5 Ma, and this possibly resulted in a tighter coupling of the Northern and Southern hemisphere climate. Increasing and decreasing the production rate of NADW on glacial-interglacial time scales may act as an interhemispheric link by altering heat and salt transport to the Southern Hemisphere. In the modern Southern Ocean, upwelling of warm deep water derived from the North Atlantic is important for retreat of Antarctic sea ice during the spring and for the basal thinning of ice shelves. A reduction in NADW, therefore, would be expected to result in an increase in the northward extent of seasonal sea ice and the position of the PFZ.

\section{CONCLUSIONS}

1. The Gauss/Matuyama boundary $(2.47 \mathrm{Ma})$ represented a time of major paleoceanographic change in the Southern Ocean. The northward migration of the PFZ at this time resulted in increased upwelling and biological productivity. This is reflected by a tenfold increase in biogenic sedimentaccumulation rates and by an increase in the importance of opal in the sediments within the Matuyama (Froelich et al., this volume).

2. At $2.47 \mathrm{Ma}$, mean planktonic and benthic $\delta^{18} \mathrm{O}$ values increased, signaling an increase in continental ice volume. This oxygen isotopic increase is coincident with a marked increase in the accumulation of ice-rafted detritus (Warnke and Allen, this volume), indicating that ice volume increased in both the Northern and Southern hemispheres at $\sim 2.4 \mathrm{Ma}$.

3. Benthic carbon isotopic values indicate that the ventilation rate of Southern Ocean deep water decreased significantly during glacial events after $2.47 \mathrm{Ma}$. Benthic carbon isotopic values of the Southern Ocean shifted toward the
Pacific end member at this time, implying a decrease in the relative mixing ratio of $\mathrm{NCW}$ and $\mathrm{CPDW}$.

4. Between 2.3 and $1.7 \mathrm{Ma}$, the PFZ generally occupied a southerly position with respect to Site 704 except during strong glacial stages $(82,78,74$, and 70$)$ when the PFZ migrated north. Between 1.7 and $1.5 \mathrm{Ma}$, the PFZ generally occupied a more northerly position and opal sedimentation prevailed at Site 704 .

5. Between 1.4 and 1.0 Ma, the subantarctic South Atlantic surface and bottom water parameters $\left(\delta^{18} \mathrm{O}, \delta^{13} \mathrm{C}, \% \mathrm{CaCO}_{3}\right.$, and \%opal) were correlated with variations in Northern Hemisphere ice volume. Carbonate stratigraphy exhibits a typical Atlantic-type pattern in which glacial intervals (high $\delta^{18} \mathrm{O}$ ) are correlated with carbonate minima (opal maxima). The onset of tighter coupling between the Northern and Southern hemisphere climate between 1.5 and $1.4 \mathrm{Ma}$ may have been related to increased suppression of NADW during glacial events after 1.5 Ma (Raymo et al., 1990).

\section{ACKNOWLEDGMENTS}

We thank R. Cooke and M. Shultz for assistance in preparing foraminiferal samples for isotopic analysis and $\mathbf{J}$. Garrido for assistance in analyzing samples on the mass spectrometer and coulometer. We thank the crew and scientific party of Leg 114, without whom this work would not have been possible. Discussions with P. Froelich, G. Mead, D. Müller, and D. Warnke were particularly helpful for developing and clarifying the ideas presented herein. T. Moore, S. Savin, and an anonymous reviewer provided insightful reviews that significantly improved the quality of the manuscript. We thank Susan Case Ciesielski for editorial and illustrative assistance and P. Catanzaro for drafting assistance. This research was supported by U.S. Science Program 


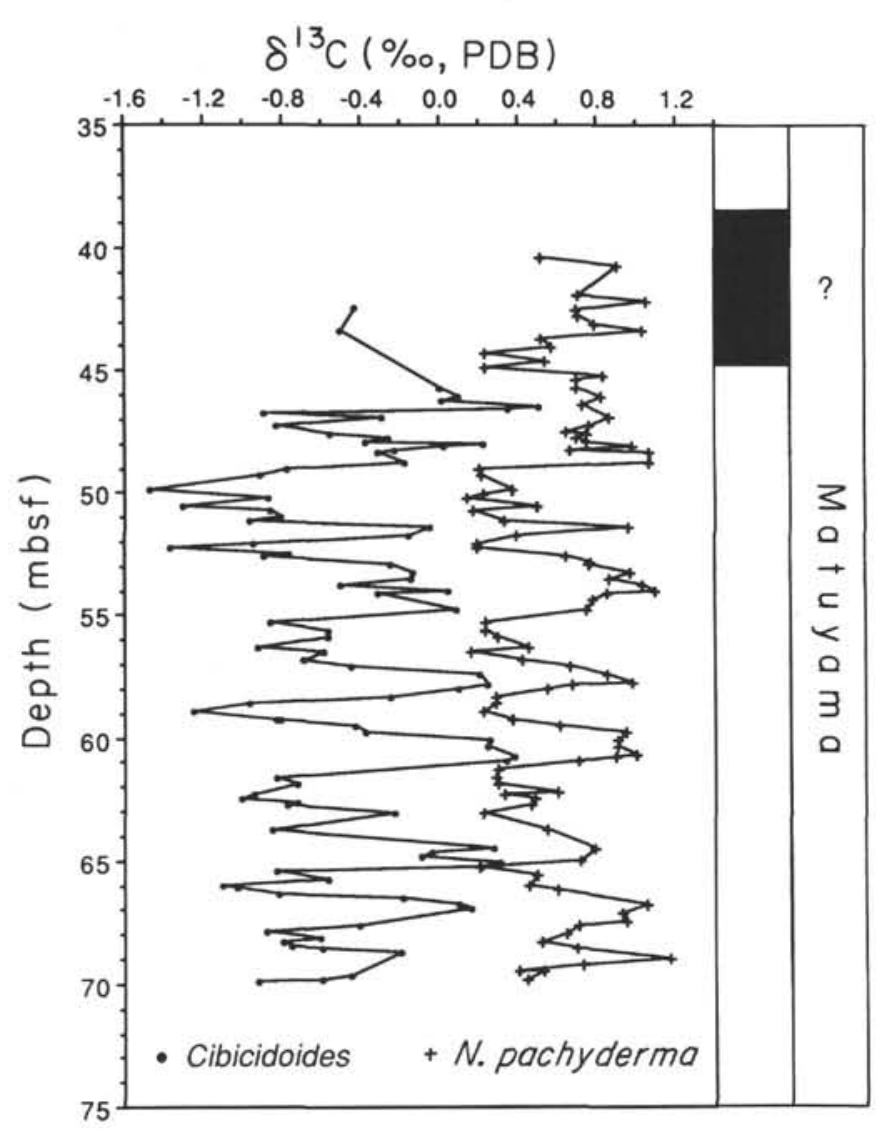

Figure 13. Carbon isotopic results of planktonic (N. pachyderma) and benthic (Cibicidoides) foraminifers between 70 and 40 mbsf in Hole 704A. Minima in planktonic and benthic $\delta^{13} \mathrm{C}$ values correspond with maxima in the $\delta^{18} \mathrm{O}$ record and with minima in the carbonate record (Fig. 12).

(USSAC) Grant \#20114 and NSF Grant \#OCE-8858012 to DAH, USSAC Grant \#20115 to PFC, and NSF Grant \#DPP8717854 to PFC and DAH.

\section{REFERENCES}

Abelman, A., and Gersonde, R., 1990. Plio-Pleistocene paleoceanography in the Weddell Sea-siliceous microfossil evidence. In Bleil, U., and Thiede, J. (Eds.), Geologic History of the Polar Oceans: Arctic versus Antarctic: NATO ASI Ser., 729-760.

Berggren, W. A., Kent, D. V., and Van Couvering, J. A., 1985. The Neogene: Part 2. Neogene geochronology and chronostratigraphy, In Snelling, N. J. (Ed.), The Chronology of the Geological Record: Geol. Soc. London Mem., 10:211-260.

Bornhold, B. D., 1983. Ice-rafted debris in sediments from Leg 71, southwest Atlantic Ocean. In Ludwig, W. J., Krasheninnikov, V. A., et al., Init. Repts. DSDP, 71: Washington (U.S. Govt. Printing Office), 307-316.

Burckle, L. H., and Cirilli, J., 1987. Origin of diatom ooze belt in the Southern Ocean: implications for late Quaternary paleoceanography. Micropaleontology, 33:82-86.

Charles, C. D., and Fairbanks, R. G., 1990. Glacial to interglacial changes in the stable isotopic composition of surface and deep waters in the Southern Ocean. In Bleil, U., and Thiede, J. (Eds.), Geologic History of the Polar Oceans: Arctic versus Antarctic: NATO ASI Ser., 519-538.

Ciesielski, P. F., 1983. The Neogene and Quaternary diatom biostratigraphy of subantarctic sediments, Deep Sea Drilling Leg 71. In Ludwig, W. J., Krasheninnikov, V. A., et al., Init. Repts. DSDP, 71: Washington (U.S. Govt. Printing Office), 635-665.
Ciesielski, P. F., and Grinstead, G. P., 1986. Pliocene variations in the position of the Antarctic Convergence in the southwest Atlantic. Paleoceanography, 1:197-232.

Curry, W. B., and Miller, K. G., 1990. Oxygen and carbon isotopic variation in Pliocene benthic foraminifera of the equatorial Atlantic. In Ruddiman, W. F., Sarnthein, M., Baldauf, J., et al., Proc. ODP, Sci. Results, 108: College Station, TX (Ocean Drilling Program), 157-166.

Denton, G. H., Prentice, M. L., Kellogg, D. E., and Kellogg, T. B., 1984. Late Tertiary history of the Antarctic ice sheet: evidence from the Dry Valleys. Geology, 12:263-267.

Goodney, D. E., Margolis, S. V., Dudley, W. C., Kroopnick, P., and Williams, D. F., 1980. Oxygen and carbon isotopes of Recent calcareous nannofossils as paleoceanographic indicators. Mar. Micropaleont., 5:31-42.

Gordon, A. L., and Molinelli, E. J., 1982. Thermohaline and chemical distributions and the atlas data set. In Gordon, A. L., and Molinelli, E. J. (Eds.), Southern Ocean Atlas: New York (Columbia Univ. Press), 1-11.

Graham, D. W., Corliss, B. H., Bender, M. L., and Keigwin, L. D., $\mathrm{Jr}$., 1981. Carbon and oxygen isotopic disequilibria of Recent deep-sea benthic foraminifera. Mar. Micropaleontol., 6:483497.

Hays, J. D., Lozano, J. A., Shackleton, N. J., and Irving, G., 1976. Reconstruction of the Atlantic and western Indian Ocean sectors of the 18,000 B. P. Antarctic Ocean. In Cline, R. M., and Hays, J. D. (Eds.), Investigations of Late Quaternary Paleoceanography and Paleoclimatology: Mem. Geol. Soc. Am., 145:337-372.

Hodell, D. A., Benson, R. H., Kennett, J. P., and Rakic, K.E.B., 1989. Stable isotope stratigraphy of late Miocene-early Pliocene sequences in northwest Morocco: the Bou Regreg Section. Paleoceanography, 4:467-482.

Jansen, E., Bleil, U., Henrich, R., Kringstad, L., and Slettemark, B., 1988. Paleoenvironmental changes in the Norwegian Sea and the northeast Atlantic during the last 2.8 m.y.: Deep Sea Drilling Project/Ocean Drilling Program Sites 610, 642, and 644. Paleoceanography, 3:563-581.

Jansen, E., Sjoholm, J., Bleil, U., and Erichsen, J. A., 1990. Neogene and Pleistocene glaciations in the Northern Hemisphere and Miocene-Pliocene global ice volume fluctuations: evidence from the Norwegian Sea. In Bleil, U., and Thiede, J. (Eds.), Geologic History of the Polar Oceans: Arctic versus Antarctic: NATO ASI Ser., 677-706.

Keigwin, L. D., Jr., 1986. Pliocene stable isotope record of Deep Sea Drilling Project Site 606: sequential event of ${ }^{18} \mathrm{O}$ enrichment beginning at 3.1 Ma. In Ruddiman, W. F., Kidd, R. B., Thomas, E., et al., Init. Repts. DSDP, 94: Washington (U.S. Govt. Printing Office), 911-920.

Kroopnick, P. M., 1974. Correlations between ${ }^{13} \mathrm{C}$ and $\Sigma \mathrm{CO}_{2}$ in surface waters and atmospheric $\mathrm{CO}_{2}$. Earth Planet. Sci. Lett., 22:397-403.

Labeyrie, L., Pichon, J.-J., Labracherie, M., Ippolito, P., Duprat, J., and Duplessy, J.-C., 1986. Melting history of Antarctica during the past 60,000 years. Nature, 322:701-706.

Lutjeharms, J.R.E., 1985. Location of frontal systems between Africa and Antarctica: some preliminary results. Deep-Sea Res., Part A, 32:1499-1509.

Mayewski, P. A., 1975. Glacial Geology and Late Cenozoic History of the Transantarctic Mountains, Antarctica: Inst. Polar Stud., Rep., 56.

Oppo, D. W., and Fairbanks, R. G., 1987. Variability in the deep and intermediate water circulation of the Atlantic Ocean during the past 25,000 years: Northern Hemisphere modulation of the Southern Ocean. Earth Planet. Sci. Lett., 86:1-15.

Prentice, M. L., Denton, G. H., Lowell, T. V., Conway, H. C., and Heusser, L. E., 1986. Pre-late Quaternary glaciation of the Beardmore Glacier region, Antarctica. Antarctic J., 21:95-98.

Raymo, M. E., Ruddiman, W. F., Backman, J., Clement, B. M., and Martinson, D. G., 1989. Late Pliocene variation in Northern Hemisphere ice sheets and North Atlantic Deep Water circulation. Paleoceanography, 4:413-446.

Raymo, M. E., Ruddiman, W. F., Shackleton, N. J., and Oppo, D. W., 1990. The evolution of Atlantic-Pacific $\delta^{13} \mathrm{C}$ gradients over the last 2.5 Myrs: evidence for decoupling of deep ocean circulation 
and global ice volume changes. Earth Planet. Sci. Lett., 97:353368.

Reynolds, L. A., and Thunell, R. C., 1986. Seasonal production and morphologic variation of Neogloboquadrina pachyderma (Ehrenberg) in the northeast Pacific. Micropaleontology, 32:1-18.

Ruddiman, W. F., Cameron, D., and Clement, B. M., 1986a. Sediment disturbance and correlation of offset holes drilled with the hydraulic piston corer. In Ruddiman, W. F., Kidd, R. B., Thomas, E., et al., Init. Repts. DSDP, 94: Washington (U.S. Govt. Printing Office), 615-634.

Ruddiman, W. F., Raymo, M. E., Martinson, D. G., Clement, B. M, and Backman, J., 1989. Pleistocene evolution of Northern Hemisphere climate. Paleoceanography, 4(4): 353-412.

Ruddiman, W. F., Raymo, M. E., and McIntyre, A., 1986b. Matuyama 41,000-year cycles: North Atlantic Ocean and Northern Hemisphere ice sheets. Earth Planet. Sci. Lett., 80:117-129.
Shackleton, N. J., Backman, J., Zimmerman, H., Kent, D. V., Hall, M. A., Roberts, D. G., Schnitker, D., Baldauf, J., Desprairies, A., Homrighausen, R., Huddlestun, P., Keene, J. B., Kaltenback, A. J., Krumsiek, K.A.O., Morton, A. C., Murray, J. W., and Westberg-Smith, J., 1984. Oxygen isotope calibration of the onset of ice-rafting and history of glaciation in the North Atlantic region. Nature, 307:620-623.

Date of initial receipt: 3 May 1989

Date of acceptance: 12 December 1989

Ms 114B-150

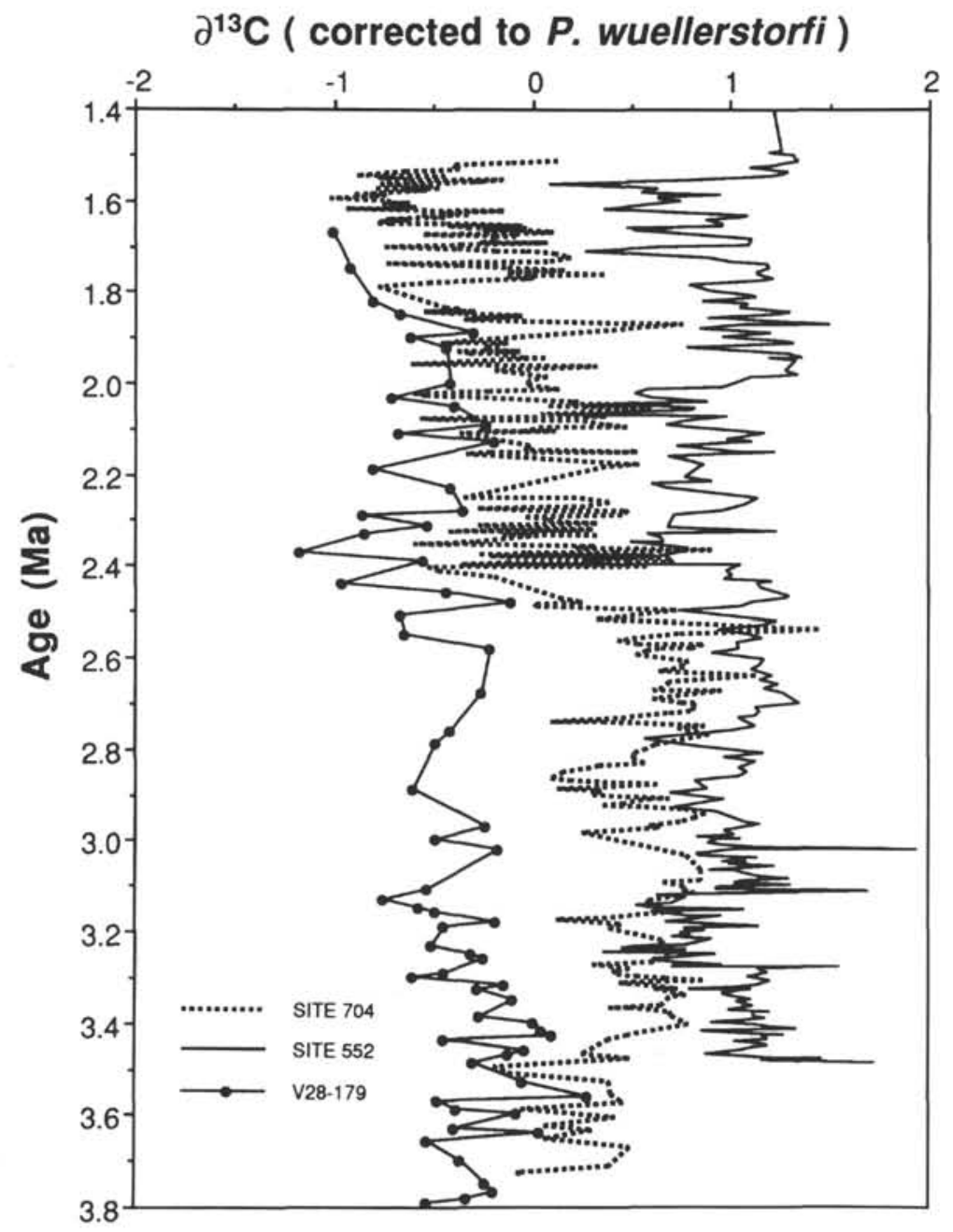

Figure 14. Carbon isotopic records (corrected for species fractionation to Planulina wuellerstorfi) from Hole 552A (North Atlantic), Site 704 (Southern Ocean), and Core V28-179 (Pacific). Between 3.5 and 2.5 Ma, Southern Ocean Site 704 $\delta^{13} \mathrm{C}$ values are intermediate between those of the North Atlantic and Pacific, but generally plot closer to the North Atlantic end member. At $2.5 \mathrm{Ma}$, Site $704 \delta^{13} \mathrm{C}$ values decrease abruptly and shift toward the Pacific end member. This change is interpreted as representing a decrease in the mixing ratio of Northern Component Water and Circumpolar Deep Water in the Southern Ocean during the Matuyama Chron. 
Table 1. Oxygen and carbon isotopic results of the planktonic foraminifer Neogloboquadrina pachyderma (sinistral) from ODP Site 704.

\begin{tabular}{|c|c|c|c|}
\hline $\begin{array}{l}\text { Core, section, } \\
\text { interval }(\mathrm{cm})\end{array}$ & $\begin{array}{l}\text { Depth } \\
\text { (mbsf) }\end{array}$ & $\begin{array}{c}\delta^{18} \mathrm{O} \\
(\% \mathrm{PDB})\end{array}$ & $\begin{array}{c}\delta^{13} \mathrm{C} \\
(\% \mathrm{PDB})\end{array}$ \\
\hline $114-704 \mathrm{~A}-$ & & & \\
\hline $1 \mathrm{H}-1,40-42$ & 0.41 & 3.03 & 0.43 \\
\hline $1 \mathrm{H}-1,76-80$ & 0.78 & 3.35 & 0.46 \\
\hline $1 \mathrm{H}-1,108-112$ & 1.10 & 2.86 & 0.67 \\
\hline $1 \mathrm{H}-2,40-42$ & 1.91 & 2.59 & 0.33 \\
\hline $1 \mathrm{H}-2,108-112$ & 2.61 & 2.01 & -0.46 \\
\hline $1 \mathrm{H}-2,115-117$ & 2.66 & 2.28 & 0.57 \\
\hline $1 \mathrm{H}-3,40-42$ & 3.41 & 2.47 & 0.26 \\
\hline $1 \mathrm{H}-3,76-80$ & 3.78 & 1.98 & -0.43 \\
\hline $1 \mathrm{H}-3,108-112$ & 4.09 & 2.43 & 0.37 \\
\hline $1 \mathrm{H}-4,40-42$ & 4.91 & 2.17 & 1.00 \\
\hline $1 \mathrm{H}-4,76-80$ & 5.28 & 2.63 & 0.50 \\
\hline $1 \mathrm{H}-4,108-112$ & 5.60 & 2.21 & 0.81 \\
\hline $1 \mathrm{H}-4,123-127$ & 5.75 & 2.07 & 0.43 \\
\hline $1 \mathrm{H}-5,19-23$ & 6.21 & 2.37 & 0.70 \\
\hline $1 \mathrm{H}-5,40-42$ & 6.41 & 3.03 & 0.43 \\
\hline $1 \mathrm{H}-5,40-42$ & 6.41 & 2.22 & 0.56 \\
\hline $1 \mathrm{H}-5,76-80$ & 6.78 & 2.19 & 0.75 \\
\hline $1 \mathrm{H}-5,108-112$ & 7.10 & 2.58 & 0.95 \\
\hline $2 \mathrm{H}-1,40-42$ & 7.61 & 2.05 & 0.89 \\
\hline $2 \mathrm{H}-1,80-84$ & 8.02 & 2.13 & 0.49 \\
\hline $2 \mathrm{H}-1,80-84$ & 8.02 & 2.50 & 0.27 \\
\hline $2 \mathrm{H}-1,130-134$ & 8.52 & 3.13 & 0.61 \\
\hline $2 \mathrm{H}-2,40-42$ & 9.11 & 3.21 & 1.08 \\
\hline $2 \mathrm{H}-3,40-42$ & 10.61 & 3.45 & 0.38 \\
\hline $2 \mathrm{H}-3,130-134$ & 11.52 & 3.34 & 0.53 \\
\hline $2 \mathrm{H}-3,130-134$ & 11.52 & 3.36 & 0.53 \\
\hline $2 \mathrm{H}-4,80-84$ & 12.52 & 2.21 & 0.18 \\
\hline $2 \mathrm{H}-4,80-84$ & 12.52 & 2.43 & 0.58 \\
\hline $2 \mathrm{H}-4,130-134$ & 13.02 & 3.05 & 0.65 \\
\hline $2 \mathrm{H}-4,130-134$ & 13.02 & 3.33 & 0.00 \\
\hline $2 \mathrm{H}-5,40-42$ & 13.61 & 2.53 & 0.74 \\
\hline $2 \mathrm{H}-5,80-84$ & 14.02 & 2.42 & 0.81 \\
\hline $2 \mathrm{H}-5,130-134$ & 14.52 & 2.88 & 0.89 \\
\hline $2 \mathrm{H}-6,40-42$ & 15.11 & 2.75 & 0.24 \\
\hline $2 \mathrm{H}-6,80-84$ & 15.52 & 3.26 & 0.23 \\
\hline $2 \mathrm{H}-6,130-134$ & 16.02 & 3.06 & -0.13 \\
\hline $2 \mathrm{H}-7,40-42$ & 16.61 & 3.44 & -0.18 \\
\hline $3 \mathrm{H}-1,26-30$ & 16.98 & 3.30 & 0.12 \\
\hline $3 \mathrm{H}-1,80-84$ & 17.52 & 3.06 & 0.26 \\
\hline $3 \mathrm{H}-1,80-84$ & 17.52 & 3.12 & 0.30 \\
\hline $3 \mathrm{H}-2,26-30$ & 18.48 & 2.35 & 0.69 \\
\hline $3 \mathrm{H}-2,80-84$ & 19.02 & 2.26 & 0.81 \\
\hline $3 \mathrm{H}-2,115-117$ & 19.36 & 2.35 & 0.89 \\
\hline $3 \mathrm{H}-3,26-30$ & 19.98 & 2.30 & 0.90 \\
\hline $3 \mathrm{H}-3,80-84$ & 20.52 & 2.47 & 0.71 \\
\hline $3 \mathrm{H}-3,115-117$ & 20.86 & 2.28 & 0.96 \\
\hline $3 \mathrm{H}-4,115-117$ & 22.36 & 3.15 & 0.16 \\
\hline $3 \mathrm{H}-5,26-30$ & 22.98 & 2.83 & 0.37 \\
\hline $3 \mathrm{H}-5,110-112$ & 23.81 & 2.64 & -0.07 \\
\hline $3 \mathrm{H}-5,80-84$ & 23.52 & 2.81 & 0.68 \\
\hline $3 \mathrm{H}-5,115-117$ & 23.86 & 2.82 & 0.46 \\
\hline $3 H-6,26-30$ & 24.48 & 2.72 & 0.43 \\
\hline $3 \mathrm{H}-6,80-84$ & 25.02 & 2.79 & 0.44 \\
\hline $3 \mathrm{H}-6,115-117$ & 25.36 & 2.79 & 0.40 \\
\hline $5 \mathrm{H}-1,20-22$ & 35.91 & 2.43 & 0.27 \\
\hline $5 \mathrm{H}-1,50-52$ & 36.21 & 2.38 & 0.38 \\
\hline $5 \mathrm{H}-2,20-22$ & 37.41 & 2.49 & 0.42 \\
\hline $5 \mathrm{H}-2,50-52$ & 37.71 & 2.78 & 0.59 \\
\hline $5 \mathrm{H}-2,80-82$ & 38.01 & 2.40 & 0.35 \\
\hline $5 \mathrm{H}-3,20-22$ & 38.91 & 2.69 & 0.61 \\
\hline
\end{tabular}

\begin{tabular}{|c|c|c|c|}
\hline $\begin{array}{l}\text { Core, section, } \\
\text { interval }(\mathrm{cm})\end{array}$ & $\begin{array}{l}\text { Depth } \\
\text { (mbsf) }\end{array}$ & $\begin{array}{c}\delta^{18} \mathrm{O} \\
(\% \mathrm{PDB})\end{array}$ & $\begin{array}{c}\delta^{13} \mathrm{C} \\
(\% \text { PDB })\end{array}$ \\
\hline $5 \mathrm{H}-3,50-52$ & 39.21 & 2.48 & 0.74 \\
\hline $5 \mathrm{H}-3,50-52$ & 39.21 & 2.48 & 0.78 \\
\hline $5 \mathrm{H}-3,80-82$ & 39.51 & 2.67 & 0.54 \\
\hline $5 \mathrm{H}-4,20-22$ & 40.41 & 2.75 & 0.52 \\
\hline $5 H-4,50-52$ & 40.71 & 2.69 & 0.90 \\
\hline $5 \mathrm{H}-5,20-22$ & 41.91 & 2.98 & 0.71 \\
\hline $5 \mathrm{H}-5,50-52$ & 42.21 & 2.57 & 1.05 \\
\hline $5 \mathrm{H}-5,80-82$ & 42.51 & 2.82 & 0.70 \\
\hline $5 \mathrm{H}-5,110-112$ & 42.81 & 2.85 & 0.71 \\
\hline $5 \mathrm{H}-5,140-142$ & 43.11 & 2.72 & 0.79 \\
\hline $5 \mathrm{H}-6,19-23$ & 43.41 & 2.69 & 1.03 \\
\hline $5 \mathrm{H}-6,50-52$ & 43.71 & 3.25 & 0.52 \\
\hline $5 \mathrm{H}-6,80-82$ & 44.01 & 3.15 & 0.57 \\
\hline $5 \mathrm{H}-6,110-112$ & 44.31 & 3.30 & 0.23 \\
\hline $5 \mathrm{H}-6,140-142$ & 44.61 & 2.96 & 0.54 \\
\hline $5 \mathrm{H}-7,20-22$ & 44.90 & 2.68 & 0.23 \\
\hline $5 \mathrm{H}-7, \mathrm{CC}$ & 45.25 & 2.32 & 0.83 \\
\hline $6 \mathrm{H}-1,19-21$ & 45.40 & 2.15 & 0.69 \\
\hline $6 \mathrm{H}-1,54-56$ & 45.70 & 2.29 & 0.70 \\
\hline $6 \mathrm{H}-1,84-86$ & 46.10 & 2.24 & 0.82 \\
\hline $6 \mathrm{H}-1,119-121$ & 46.40 & 2.54 & 0.73 \\
\hline $6 \mathrm{H}-2,19-21$ & 46.90 & 2.64 & 0.86 \\
\hline $6 \mathrm{H}-2,54-56$ & 47.25 & 2.83 & 0.76 \\
\hline $6 \mathrm{H}-2,84-86$ & 47.55 & 2.82 & 0.64 \\
\hline $6 \mathrm{H}-2,90-92$ & 47.61 & 2.39 & 0.75 \\
\hline $6 \mathrm{H}-2,105-107$ & 47.76 & 2.57 & 0.69 \\
\hline $6 \mathrm{H}-2,120-124$ & 47.90 & 2.39 & 0.75 \\
\hline $6 \mathrm{H}-2,140-142$ & 48.11 & 2.50 & 0.98 \\
\hline $6 \mathrm{H}-2,4-6$ & 48.25 & 2.50 & 0.66 \\
\hline $6 \mathrm{H}-3,19-21$ & 48.40 & 2.52 & 1.06 \\
\hline $6 \mathrm{H}-3,54-56$ & 48.75 & 2.58 & 1.06 \\
\hline $6 \mathrm{H}-3,84-86$ & 49.05 & 3.52 & 0.20 \\
\hline $6 \mathrm{H}-3,105-107$ & 49.26 & 3.59 & 0.21 \\
\hline $6 \mathrm{H}-4,19-21$ & 49.90 & 3.62 & 0.37 \\
\hline $6 \mathrm{H}-4,34-36$ & 50.05 & 3.37 & 0.22 \\
\hline $6 \mathrm{H}-4,54-56$ & 50.25 & 3.43 & 0.14 \\
\hline $6 \mathrm{H}-4,85-87$ & 50.55 & 3.40 & 0.49 \\
\hline $6 \mathrm{H}-4,105-107$ & 50.76 & 3.51 & 0.17 \\
\hline $6 \mathrm{H}-4,140-142$ & 51.11 & 3.29 & 0.33 \\
\hline $6 \mathrm{H}-5,19-21$ & 51.40 & 2.68 & 0.96 \\
\hline $6 \mathrm{H}-5,54-56$ & 51.75 & 2.22 & 0.39 \\
\hline $6 \mathrm{H}-5,84-86$ & 52.05 & 3.17 & 0.19 \\
\hline $6 \mathrm{H}-5,105-107$ & 52.26 & 3.38 & 0.19 \\
\hline $6 \mathrm{H}-5,140-142$ & 52.61 & 3.07 & 0.64 \\
\hline $6 \mathrm{H}-6,15-17$ & 52.86 & 2.50 & 0.77 \\
\hline $6 \mathrm{H}-6,19-21$ & 52.90 & 2.79 & 0.76 \\
\hline $6 \mathrm{H}-6,54-56$ & 53.25 & 2.63 & 0.97 \\
\hline $6 \mathrm{H}-6,84-86$ & 53.55 & 2.49 & 0.86 \\
\hline $6 \mathrm{H}-6,105-107$ & 53.76 & 2.39 & 1.03 \\
\hline $6 \mathrm{H}-6,130-134$ & 54.02 & 2.53 & 1.09 \\
\hline $6 \mathrm{H}-6,140-142$ & 54.11 & 2.41 & 0.85 \\
\hline $6 \mathrm{H}-7,19-21$ & 54.40 & 2.55 & 0.78 \\
\hline $6 \mathrm{H}-7,54-56$ & 54.75 & 2.37 & 0.75 \\
\hline $7 \mathrm{H}-1,59-61$ & 55.30 & 2.94 & 0.23 \\
\hline $7 \mathrm{H}-1,90-92$ & 55.61 & 2.97 & 0.23 \\
\hline $7 \mathrm{H}-1,119-121$ & 55.90 & 2.87 & 0.29 \\
\hline $7 \mathrm{H}-2,10-12$ & 56.31 & 3.19 & 0.45 \\
\hline $7 \mathrm{H}-2,29-31$ & 56.50 & 3.26 & 0.16 \\
\hline $7 \mathrm{H}-2,59-61$ & 56.80 & 3.28 & 0.42 \\
\hline $7 \mathrm{H}-2,90-92$ & 57.11 & 3.17 & 0.66 \\
\hline $7 \mathrm{H}-2,119-121$ & 57.41 & 2.21 & 0.85 \\
\hline
\end{tabular}


Table 1 (continued).

\begin{tabular}{|c|c|c|c|}
\hline $\begin{array}{l}\text { Core, section, } \\
\text { interval }(\mathrm{cm})\end{array}$ & $\begin{array}{l}\text { Depth } \\
\text { (mbsf) }\end{array}$ & $\begin{array}{c}\delta^{18} \mathrm{O} \\
\left(\%{ }_{\infty} \text { PDB }\right)\end{array}$ & $\begin{array}{c}\delta^{13} \mathrm{C} \\
(\% \text { PDB })\end{array}$ \\
\hline $7 \mathrm{H}-3,2-6$ & 57.74 & 2.53 & 0.98 \\
\hline $7 \mathrm{H}-3,10-12$ & 57.81 & 2.36 & 0.67 \\
\hline $7 \mathrm{H}-3,29-31$ & 58.00 & 2.28 & 0.55 \\
\hline $7 \mathrm{H}-3,59-61$ & 58.30 & 2.84 & 0.28 \\
\hline $7 \mathrm{H}-3,90-92$ & 58.61 & 2.82 & 0.28 \\
\hline $7 \mathrm{H}-3,119-121$ & 58.90 & 3.15 & 0.22 \\
\hline $7 \mathrm{H}-4,10-12$ & 59.31 & 3.16 & 0.37 \\
\hline $7 \mathrm{H}-4,29-31$ & 59.50 & 3.03 & 0.61 \\
\hline $7 \mathrm{H}-4,59-61$ & 59.80 & 2.94 & 0.95 \\
\hline $7 \mathrm{H}-4,90-92$ & 60.11 & 2.70 & 0.91 \\
\hline $7 \mathrm{H}-4,119-121$ & 60.40 & 2.42 & 0.91 \\
\hline $7 \mathrm{H}-5,2-6$ & 60.74 & 2.44 & 1.00 \\
\hline $7 \mathrm{H}-5,10-12$ & 60.81 & 2.22 & 0.89 \\
\hline $7 \mathrm{H}-5,29-31$ & 61.00 & 2.50 & 0.71 \\
\hline $7 \mathrm{H}-5,59-61$ & 61.30 & 2.72 & 0.29 \\
\hline $7 \mathrm{H}-5,90-92$ & 61.61 & 2.76 & 0.28 \\
\hline $7 \mathrm{H}-5,119-121$ & 61.90 & 3.10 & 0.29 \\
\hline $7 \mathrm{H}-6,2-6$ & 62.24 & 3.38 & 0.60 \\
\hline $7 \mathrm{H}-6,10-12$ & 62.31 & 3.24 & 0.33 \\
\hline $7 \mathrm{H}-6,29-31$ & 62.50 & 3.24 & 0.48 \\
\hline $7 \mathrm{H}-6,50-52$ & 62.71 & 3.22 & 0.46 \\
\hline $7 \mathrm{H}-6,90-92$ & 63.11 & 3.13 & 0.22 \\
\hline $7 \mathrm{H}-7,2-6$ & 63.74 & 3.17 & 0.55 \\
\hline $8 \mathrm{H}-1,29-3 \mathrm{I}$ & 64.50 & 2.13 & 0.79 \\
\hline $8 \mathrm{H}-1,80-82$ & 65.01 & 1.57 & 0.72 \\
\hline $8 \mathrm{H}-1,110-112$ & 65.31 & 1.92 & 0.20 \\
\hline $8 \mathrm{H}-1,139-141$ & 65.60 & 2.78 & 0.49 \\
\hline $8 \mathrm{H}-2,29-31$ & 66.00 & 3.25 & 0.45 \\
\hline $8 \mathrm{H}-2,50-52$ & 66.21 & 3.42 & 0.60 \\
\hline $8 \mathrm{H}-2,110-112$ & 66.81 & 2.88 & 1.05 \\
\hline $8 \mathrm{H}-2,139-141$ & 67.10 & 2.24 & 0.93 \\
\hline $8 \mathrm{H}-3,30-32$ & 67.51 & 2.11 & 0.95 \\
\hline $8 \mathrm{H}-3,47-49$ & 67.68 & 2.08 & 0.71 \\
\hline $8 \mathrm{H}-3,80-83$ & 68.01 & 3.74 & 0.64 \\
\hline $8 \mathrm{H}-3,110-113$ & 68.31 & 3.54 & 0.52 \\
\hline $8 \mathrm{H}-3,139-141$ & 68.60 & 3.44 & 0.69 \\
\hline $8 \mathrm{H}-4,30-32$ & 69.01 & 2.84 & 1.17 \\
\hline $8 \mathrm{H}-4,50-52$ & 69.21 & 2.25 & 0.73 \\
\hline $8 \mathrm{H}-4,80-82$ & 69.51 & 2.71 & 0.40 \\
\hline $8 \mathrm{H}-4,83-85$ & 69.54 & 2.85 & 0.53 \\
\hline $8 \mathrm{H}-4,110-112$ & 69.81 & 3.43 & 0.44 \\
\hline $8 \mathrm{H}-4,139-14 \mathrm{I}$ & 70.10 & 3.57 & 0.44 \\
\hline $8 \mathrm{H}-5,30-32$ & 70.51 & 3.29 & 0.65 \\
\hline $8 \mathrm{H}-5,50-52$ & 70.71 & 3.17 & 0.50 \\
\hline $8 \mathrm{H}-5,80-82$ & 71.01 & 3.31 & 0.93 \\
\hline $8 \mathrm{H}-5,110-112$ & 71.31 & 3.05 & 0.85 \\
\hline $8 \mathrm{H}-5,139-141$ & 71.60 & 2.87 & 0.87 \\
\hline $8 \mathrm{H}-6,1-3$ & 71.91 & 3.43 & 0.32 \\
\hline $8 \mathrm{H}-6,1-3$ & 71.91 & 3.05 & 0.41 \\
\hline $8 \mathrm{H}-6,30-32$ & 72.01 & 3.01 & 0.92 \\
\hline $8 \mathrm{H}-6,50-52$ & 72.21 & 2.97 & 1.35 \\
\hline $8 \mathrm{H}-6,80-82$ & 72.51 & 2.72 & 1.24 \\
\hline $8 \mathrm{H}-6,110-112$ & 72.81 & 2.91 & 0.97 \\
\hline $9 \mathrm{H}-1,50-52$ & 74.21 & 3.19 & 0.90 \\
\hline $9 \mathrm{H}-1,80-82$ & 74.51 & 2.76 & 1.13 \\
\hline $9 \mathrm{H}-1,110-112$ & 74.81 & 2.70 & 1.31 \\
\hline $9 \mathrm{H}-1,140-142$ & 75.11 & 2.65 & 1.15 \\
\hline $9 \mathrm{H}-2,50-52$ & 75.71 & 2.67 & 0.90 \\
\hline $9 \mathrm{H}-2,80-82$ & 76.01 & 2.89 & 0.99 \\
\hline $9 \mathrm{H}-2,110-112$ & 76.31 & 2.82 & 0.84 \\
\hline $9 \mathrm{H}-2,140-142$ & 76.61 & 2.38 & 0.46 \\
\hline
\end{tabular}

Table 1 (continued).

\begin{tabular}{|c|c|c|c|}
\hline $\begin{array}{l}\text { Core, section, } \\
\text { interval }(\mathrm{cm})\end{array}$ & $\begin{array}{l}\text { Depth } \\
\text { (mbsf) }\end{array}$ & $\begin{array}{c}\delta^{18} \mathrm{O} \\
(\% \text { PDB })\end{array}$ & $\begin{array}{c}\delta^{13} \mathrm{C} \\
\left(\%{ }_{\infty} \mathrm{PDB}\right)\end{array}$ \\
\hline $9 \mathrm{H}-3,20-22$ & 76.91 & 2.73 & 0.83 \\
\hline $9 \mathrm{H}-3,50-52$ & 77.21 & 2.73 & 0.91 \\
\hline $9 \mathrm{H}-3,80-82$ & 77.51 & 2.69 & 1.21 \\
\hline $9 \mathrm{H}-3,110-112$ & 77.81 & 2.29 & 0.56 \\
\hline $9 \mathrm{H}-3,140-142$ & 78.11 & 3.01 & 1.23 \\
\hline $9 \mathrm{H}-4,20-22$ & 78.41 & 2.46 & 0.87 \\
\hline $9 \mathrm{H}-4,50-52$ & 78.71 & 2.36 & 1.24 \\
\hline $9 \mathrm{H}-4,80-82$ & 79.01 & 2.10 & 0.58 \\
\hline $9 \mathrm{H}-4,110-112$ & 79.31 & 2.47 & 0.68 \\
\hline $9 \mathrm{H}-5,20-22$ & 79.91 & 2.70 & 0.16 \\
\hline $9 \mathrm{H}-5,50-52$ & 80.21 & 3.10 & 0.26 \\
\hline $9 \mathrm{H}-5,80-82$ & 80.51 & 3.26 & 0.03 \\
\hline $9 \mathrm{H}-5,110-112$ & 80.81 & 3.28 & 0.34 \\
\hline $9 \mathrm{H}-5,140-142$ & 81.11 & 3.14 & 0.27 \\
\hline $9 \mathrm{H}-6,50-52$ & 81.71 & 3.42 & 0.04 \\
\hline $9 \mathrm{H}-6,80-82$ & 82.01 & 3.25 & 0.09 \\
\hline $9 \mathrm{H}-6,110-112$ & 82.31 & 3.25 & 0.01 \\
\hline $9 \mathrm{H}-7,20-22$ & 82.91 & 3.30 & 0.14 \\
\hline $10 \mathrm{H}-1,19-21$ & 83.40 & 3.37 & 0.81 \\
\hline $10 \mathrm{H}-1,50-52$ & 83.71 & 3.09 & 0.38 \\
\hline $10 \mathrm{H}-1,79-81$ & 84.00 & 3.17 & 0.49 \\
\hline $10 \mathrm{H}-1,109-111$ & 84.30 & 2.94 & 0.80 \\
\hline $10 \mathrm{H}-2,19-21$ & 84.90 & 2.94 & 0.34 \\
\hline $10 \mathrm{H}-2,50-52$ & 85.21 & 2.05 & 0.00 \\
\hline $10 \mathrm{H}-2,79-81$ & 85.50 & 2.38 & 0.79 \\
\hline $10 \mathrm{H}-2,109-111$ & 85.80 & 2.35 & 0.18 \\
\hline $10 \mathrm{H}-3,20-22$ & 86.41 & 2.62 & 0.70 \\
\hline $10 \mathrm{H}-3,50-52$ & 86.71 & 2.59 & -0.01 \\
\hline $10 \mathrm{H}-3,79-81$ & 87.00 & 2.47 & -0.25 \\
\hline $10 \mathrm{H}-3,109-111$ & 87.30 & 2.64 & 0.19 \\
\hline $10 \mathrm{H}-4,19-21$ & 87.90 & 2.56 & 0.14 \\
\hline $10 \mathrm{H}-4,50-52$ & 88.21 & 2.43 & -0.11 \\
\hline $10 \mathrm{H}-4,79-81$ & 88.50 & 2.56 & 0.14 \\
\hline $10 \mathrm{H}-4,109-111$ & 88.80 & 3.08 & 0.25 \\
\hline $10 \mathrm{H}-5,19-21$ & 89.40 & 2.76 & 0.20 \\
\hline $10 \mathrm{H}-5,50-52$ & 89.71 & 3.03 & 0.22 \\
\hline $10 \mathrm{H}-5,79-81$ & 90.00 & 3.05 & 0.18 \\
\hline $10 \mathrm{H}-6,19-21$ & 90.90 & 2.81 & 0.67 \\
\hline $10 \mathrm{H}-6,50-52$ & 91.21 & 2.69 & 0.32 \\
\hline $10 \mathrm{H}-6,79-81$ & 91.50 & 2.52 & 0.44 \\
\hline $10 \mathrm{H}-6,109-111$ & 91.80 & 2.48 & 0.29 \\
\hline $10 \mathrm{H}-7,19-21$ & 92.40 & 3.60 & 0.00 \\
\hline $10 \mathrm{H}-7,45-47$ & 92.66 & 2.97 & 0.18 \\
\hline $11 \mathrm{H}-1,20-22$ & 92.91 & 2.77 & 0.80 \\
\hline $10 \mathrm{H}-7,79-81$ & 93.00 & 2.79 & 0.54 \\
\hline $11 \mathrm{H}-1,50-52$ & 93.21 & 2.51 & 0.95 \\
\hline $11 \mathrm{H}-1,80-82$ & 93.51 & 2.36 & 0.46 \\
\hline $11 \mathrm{H}-1,110-112$ & 93.81 & 2.51 & 0.99 \\
\hline $11 \mathrm{H}-1,140-142$ & 94.11 & 2.14 & 0.65 \\
\hline $11 \mathrm{H}-2,50-52$ & 94.71 & 2.01 & 0.37 \\
\hline $11 \mathrm{H}-2,80-82$ & 95.01 & 2.03 & 1.10 \\
\hline $11 \mathrm{H}-2,110-112$ & 95.31 & 2.89 & 0.33 \\
\hline $11 \mathrm{H}-2,140-142$ & 95.61 & 2.96 & 0.41 \\
\hline $11 \mathrm{H}-3,20-22$ & 95.91 & 2.70 & 0.13 \\
\hline $11 \mathrm{H}-3,50-52$ & 96.21 & 2.95 & 0.30 \\
\hline $11 \mathrm{H}-3,80-82$ & 96.51 & 2.98 & 0.55 \\
\hline $11 \mathrm{H}-3,110-112$ & 96.81 & 2.78 & 0.08 \\
\hline $11 \mathrm{H}-3,140-142$ & 97.11 & 2.67 & -0.03 \\
\hline $11 \mathrm{H}-4,20-22$ & 97.41 & 2.87 & 0.17 \\
\hline $11 \mathrm{H}-4,50-52$ & 97.71 & 2.38 & 0.53 \\
\hline $11 \mathrm{H}-4,80-82$ & 98.01 & 2.23 & 0.32 \\
\hline
\end{tabular}


Table 1 (continued).

\begin{tabular}{|c|c|c|c|}
\hline $\begin{array}{l}\text { Core, section, } \\
\text { interval }(\mathrm{cm})\end{array}$ & $\begin{array}{l}\text { Depth } \\
\text { (mbsf) }\end{array}$ & $\begin{array}{c}\delta^{18} \mathrm{O} \\
\left(\%{ }_{\infty} \mathrm{PDB}\right)\end{array}$ & $\begin{array}{c}\delta^{13} \mathrm{C} \\
(\% \text { PDB })\end{array}$ \\
\hline $11 \mathrm{H}-4,114-116$ & 98.35 & 2.27 & 0.43 \\
\hline $11 \mathrm{H}-4,140-142$ & 98.61 & 3.26 & 0.69 \\
\hline $11 \mathrm{H}-5,20-22$ & 98.91 & 2.54 & 0.83 \\
\hline $11 \mathrm{H}-5,50-52$ & 99.21 & 2.76 & 0.78 \\
\hline $11 \mathrm{H}-5,80-82$ & 99.51 & 2.55 & 0.79 \\
\hline $11 \mathrm{H}-5,110-112$ & 99.81 & 2.74 & 0.76 \\
\hline $11 \mathrm{H}-6,80-82$ & 101.01 & 2.61 & 0.98 \\
\hline $11 \mathrm{H}-5,140-142$ & 100.11 & 2.63 & 0.94 \\
\hline $11 \mathrm{H}-6,20-22$ & 100.41 & 2.55 & 0.90 \\
\hline $11 \mathrm{H}-6,50-52$ & 100.71 & 2.61 & 0.79 \\
\hline $11 \mathrm{H}-6,110-112$ & 101.31 & 2.47 & 0.76 \\
\hline $11 \mathrm{H}-6,140-142$ & 101.61 & 2.45 & 0.47 \\
\hline $11 \mathrm{H}-7,24-26$ & 101.95 & 2.65 & 0.60 \\
\hline $12 \mathrm{H}-1,20-22$ & 102.41 & 2.28 & 0.57 \\
\hline $12 \mathrm{H}-1,50-52$ & 102.71 & 2.50 & 0.26 \\
\hline $12 \mathrm{H}-1,80-82$ & 103.01 & 2.81 & 0.53 \\
\hline $12 \mathrm{H}-1,110-112$ & 103.31 & 2.92 & 0.38 \\
\hline $12 \mathrm{H}-1,140-142$ & 103.61 & 2.49 & 0.35 \\
\hline $12 \mathrm{H}-2,20-22$ & 103.91 & 2.36 & 0.65 \\
\hline $12 \mathrm{H}-2,50-52$ & 104.21 & 3.25 & 0.22 \\
\hline $12 \mathrm{H}-2,80-82$ & 104.51 & 3.21 & 0.36 \\
\hline $12 \mathrm{H}-2,110-112$ & 104.81 & 2.78 & 0.34 \\
\hline $12 \mathrm{H}-2,140-142$ & 105.11 & 2.66 & 0.46 \\
\hline $12 \mathrm{H}-3,20-22$ & 105.41 & 2.16 & 0.37 \\
\hline $12 \mathrm{H}-3,50-52$ & 105.71 & 2.29 & 0.17 \\
\hline $12 \mathrm{H}-3,80-82$ & 106.01 & 2.46 & 0.63 \\
\hline $12 \mathrm{H}-3,110-112$ & 106.31 & 2.51 & 0.79 \\
\hline $12 \mathrm{H}-3,140-142$ & 106.61 & 2.19 & 0.81 \\
\hline $12 \mathrm{H}-4,20-22$ & 106.91 & 2.94 & 0.43 \\
\hline $12 \mathrm{H}-4,50-52$ & 107.21 & 2.62 & 0.81 \\
\hline $12 \mathrm{H}-4,80-82$ & 107.51 & 2.46 & 0.52 \\
\hline $12 \mathrm{H}-4,110-112$ & 107.81 & 2.58 & 1.01 \\
\hline $12 \mathrm{H}-4,140-142$ & 108.11 & 1.96 & 0.87 \\
\hline $12 \mathrm{H}-5,20-22$ & 108.41 & 2.04 & 0.65 \\
\hline $12 \mathrm{H}-5,50-52$ & 108.71 & 2.17 & 0.76 \\
\hline $12 \mathrm{H}-5,80-82$ & 109.01 & 2.32 & 0.72 \\
\hline $12 \mathrm{H}-5,110-112$ & 109.31 & 2.32 & 0.46 \\
\hline $12 \mathrm{H}-6,20-22$ & 109.91 & 2.61 & 0.37 \\
\hline $12 \mathrm{H}-6,50-52$ & 110.21 & 2.37 & 0.45 \\
\hline $12 \mathrm{H}-6,80-82$ & 110.51 & 2.60 & 0.49 \\
\hline $12 \mathrm{H}-6,110-112$ & 110.81 & 2.45 & 0.46 \\
\hline $12 \mathrm{H}-6,140-142$ & 111.11 & 2.54 & 0.62 \\
\hline $13 \mathrm{H}-1,20-22$ & 111.91 & 2.61 & 0.48 \\
\hline $13 \mathrm{H}-1,50-52$ & 112.21 & 2.90 & 0.32 \\
\hline $13 \mathrm{H}-1,80-82$ & 112.51 & 3.36 & 0.12 \\
\hline $13 \mathrm{H}-1,95-99$ & 112.67 & 3.63 & 0.53 \\
\hline $13 \mathrm{H}-1,110-112$ & 112.81 & 3.23 & 0.22 \\
\hline $13 \mathrm{H}-1,140-142$ & 113.11 & 3.37 & 0.27 \\
\hline $13 \mathrm{H}-2,20-22$ & 113.41 & 2.49 & 0.51 \\
\hline $13 \mathrm{H}-2,50-52$ & 113.71 & 2.90 & 0.36 \\
\hline $13 \mathrm{H}-2,80-82$ & 114.01 & 3.19 & 0.12 \\
\hline $13 \mathrm{H}-2,95-99$ & 114.17 & 3.64 & 0.55 \\
\hline $13 \mathrm{H}-2,110-112$ & 114.31 & 3.29 & 0.16 \\
\hline $13 \mathrm{H}-2,140-142$ & 114.61 & 3.23 & 0.20 \\
\hline $13 \mathrm{H}-3,20-22$ & 114.91 & 2.98 & 0.48 \\
\hline $13 \mathrm{H}-3,50-52$ & 115.21 & 3.00 & 0.59 \\
\hline $13 \mathrm{H}-3,80-82$ & 115.51 & 2.61 & 0.40 \\
\hline $13 \mathrm{H}-3,110-112$ & 115.81 & 1.92 & -0.02 \\
\hline $13 \mathrm{H}-3,140-142$ & 116.11 & 2.03 & 0.34 \\
\hline $13 \mathrm{H}-4,20-22$ & 116.41 & 2.06 & -0.06 \\
\hline $13 \mathrm{H}-4,50-52$ & 116.71 & 3.03 & 0.39 \\
\hline
\end{tabular}

Table 1 (continued).

\begin{tabular}{|c|c|c|c|}
\hline $\begin{array}{l}\text { Core, section, } \\
\text { interval }(\mathrm{cm})\end{array}$ & $\begin{array}{l}\text { Depth } \\
\text { (mbsf) }\end{array}$ & $\begin{array}{c}\delta^{18} \mathrm{O} \\
(\% \infty \mathrm{PDB})\end{array}$ & $\begin{array}{c}\delta^{13} \mathrm{C} \\
(\% \text { PDB })\end{array}$ \\
\hline $13 \mathrm{H}-4,80-82$ & 117.01 & 2.61 & 0.67 \\
\hline $13 \mathrm{H}-4,110-112$ & 117.31 & 2.21 & 0.69 \\
\hline $13 \mathrm{H}-4,140-142$ & 117.61 & 2.07 & 0.55 \\
\hline $13 \mathrm{H}-5,20-22$ & 117.91 & 2.47 & 0.28 \\
\hline $13 \mathrm{H}-5,50-52$ & 118.21 & 2.94 & 0.52 \\
\hline $13 \mathrm{H}-5,80-82$ & 118.51 & 2.74 & 0.22 \\
\hline $13 \mathrm{H}-5,110-112$ & 118.81 & 2.89 & 0.80 \\
\hline $13 \mathrm{H}-5,140-142$ & 119.11 & 2.69 & 0.56 \\
\hline $13 \mathrm{H}-6,50-52$ & 119.71 & 2.54 & 0.58 \\
\hline $13 \mathrm{H}-6,80-82$ & 120.01 & 2.26 & 0.96 \\
\hline $13 \mathrm{H}-6,110-112$ & 120.31 & 1.64 & 0.24 \\
\hline $13 \mathrm{H}-6,140-142$ & 120.61 & 2.08 & 0.78 \\
\hline $13 \mathrm{H}-7,20-22$ & 120.91 & 2.12 & 0.86 \\
\hline $13 \mathrm{H}-7,50-52$ & 121.21 & 2.15 & 0.89 \\
\hline $14 \mathrm{H}-1,20-22$ & 121.41 & 2.78 & 0.63 \\
\hline $14 \mathrm{H}-1,50-52$ & 121.71 & 2.75 & 0.89 \\
\hline $14 \mathrm{H}-1,80-82$ & 122.01 & 2.80 & 0.81 \\
\hline $14 \mathrm{H}-1,109-111$ & 122.30 & 2.32 & 0.73 \\
\hline $14 \mathrm{H}-1,139-141$ & 122.60 & 2.37 & 0.62 \\
\hline $14 \mathrm{H}-2,20-22$ & 122.91 & 2.83 & 0.48 \\
\hline $14 \mathrm{H}-2,50-52$ & 123.21 & 2.52 & 0.46 \\
\hline $14 \mathrm{H}-2,80-82$ & 123.51 & 2.60 & 0.61 \\
\hline $14 \mathrm{H}-2,109-111$ & 123.80 & 2.73 & 0.84 \\
\hline $14 \mathrm{H}-2,139-141$ & 124.10 & 2.29 & 0.73 \\
\hline $14 \mathrm{H}-3,20-22$ & 124.41 & 2.52 & 0.48 \\
\hline $14 \mathrm{H}-3,40-44$ & 124.62 & 3.14 & 0.95 \\
\hline $14 \mathrm{H}-3,50-52$ & 124.71 & 2.72 & 0.55 \\
\hline $14 \mathrm{H}-3,50-52$ & 124.71 & 2.99 & 0.66 \\
\hline $14 \mathrm{H}-3,80-82$ & 125.01 & 2.29 & 0.89 \\
\hline $14 \mathrm{H}-3,109-111$ & 125.30 & 2.36 & 0.64 \\
\hline $14 \mathrm{H}-3,139-141$ & 125.60 & 2.41 & 0.87 \\
\hline $14 \mathrm{H}-4,20-22$ & 125.91 & 2.76 & 0.80 \\
\hline $14 \mathrm{H}-4,40-44$ & 126.12 & 3.18 & 0.99 \\
\hline $14 \mathrm{H}-4,50-52$ & 126.21 & 3.00 & 0.78 \\
\hline $14 \mathrm{H}-4,80-82$ & 126.51 & 2.52 & 0.73 \\
\hline $14 \mathrm{H}-4,109-111$ & 126.80 & 2.42 & 0.84 \\
\hline $14 \mathrm{H}-4,139-141$ & 127.10 & 2.17 & 0.34 \\
\hline $14 \mathrm{H}-5,20-22$ & 127.41 & 2.75 & 0.35 \\
\hline $14 \mathrm{H}-5,40-44$ & 127.62 & 3.34 & 0.73 \\
\hline $14 \mathrm{H}-5,50-52$ & 127.71 & 2.47 & 0.76 \\
\hline $14 \mathrm{H}-5,109-111$ & 128.30 & 2.76 & 0.73 \\
\hline $14 \mathrm{H}-5,139-141$ & 128.60 & 2.65 & 0.53 \\
\hline $14 \mathrm{H}-6,20-22$ & 128.91 & 2.47 & 0.47 \\
\hline $14 \mathrm{H}-6,40-44$ & 129.12 & 3.00 & 0.66 \\
\hline $14 \mathrm{H}-6,50-52$ & 129.21 & 3.08 & 0.37 \\
\hline $14 \mathrm{H}-6,80-82$ & 129.51 & 2.76 & 0.48 \\
\hline $15 \mathrm{H}-1,20-22$ & 130.91 & 2.40 & 0.67 \\
\hline $15 \mathrm{H}-1,20-22$ & 130.91 & 2.91 & 0.73 \\
\hline $15 \mathrm{H}-1,50-52$ & 131.21 & 2.73 & 0.92 \\
\hline $15 \mathrm{H}-1,80-82$ & 131.51 & 2.84 & 1.01 \\
\hline $15 \mathrm{H}-1,110-112$ & 131.81 & 2.74 & 0.66 \\
\hline $15 \mathrm{H}-1,137-139$ & 132.08 & 2.76 & 0.58 \\
\hline $15 \mathrm{H}-1,137-139$ & 132.08 & 2.71 & 1.05 \\
\hline $15 \mathrm{H}-2,20-22$ & 132.41 & 2.69 & 1.03 \\
\hline $15 \mathrm{H}-2,50-52$ & 132.71 & 2.63 & 0.83 \\
\hline $15 \mathrm{H}-2,80-82$ & 133.01 & 2.51 & 0.78 \\
\hline $15 \mathrm{H}-2,110-112$ & 133.31 & 2.38 & 0.88 \\
\hline $15 \mathrm{H}-2,140-142$ & 133.61 & 2.43 & 0.86 \\
\hline $15 \mathrm{H}-3,20-22$ & 133.91 & 2.55 & 1.15 \\
\hline $15 \mathrm{H}-3,50-52$ & 134.21 & 2.58 & 1.20 \\
\hline $15 \mathrm{H}-3,80-82$ & 134.51 & 2.72 & 1.20 \\
\hline
\end{tabular}


Table 1 (continued).

\begin{tabular}{|c|c|c|c|}
\hline $\begin{array}{l}\text { Core, section, } \\
\text { interval }(\mathrm{cm})\end{array}$ & $\begin{array}{l}\text { Depth } \\
\text { (mbsf) }\end{array}$ & $\begin{array}{c}\delta^{18} \mathrm{O} \\
\left(\%{ }_{\infty} \text { PDB }\right)\end{array}$ & $\begin{array}{c}\delta^{13} \mathrm{C} \\
\left(\%{ }^{\circ} \mathrm{PDB}\right)\end{array}$ \\
\hline $15 \mathrm{H}-3,110-112$ & 134.81 & 2.39 & 0.85 \\
\hline $15 \mathrm{H}-3,140-142$ & 135.11 & 2.39 & 0.59 \\
\hline $15 \mathrm{H}-4,20-22$ & 135.41 & 2.73 & 0.69 \\
\hline $15 \mathrm{H}-4,50-52$ & 135.71 & 2.45 & 1.03 \\
\hline $15 \mathrm{H}-4,80-82$ & 136.01 & 2.75 & 0.74 \\
\hline $15 \mathrm{H}-4,110-112$ & 136.31 & 2.64 & 0.94 \\
\hline $15 \mathrm{H}-4,140-142$ & 136.61 & 3.01 & 0.91 \\
\hline $15 \mathrm{H}-5,20-22$ & 136.91 & 2.42 & 0.94 \\
\hline $15 \mathrm{H}-5,50-52$ & 137.21 & 2.89 & 0.67 \\
\hline $15 \mathrm{H}-5,80-82$ & 137.51 & 2.67 & 0.90 \\
\hline $15 \mathrm{H}-5,110-112$ & 137.81 & 2.63 & 0.86 \\
\hline $15 \mathrm{H}-6,110-112$ & 137.81 & 2.59 & 0.99 \\
\hline $15 \mathrm{H}-6,20-22$ & 138.41 & 2.29 & 0.59 \\
\hline $15 \mathrm{H}-6,50-52$ & 138.71 & 2.55 & 0.58 \\
\hline $15 \mathrm{H}-6,80-82$ & 139.01 & 2.20 & 0.43 \\
\hline $15 \mathrm{H}-6,80-82$ & 139.01 & 2.50 & 0.65 \\
\hline $15 \mathrm{H}-6,110-112$ & 139.31 & 2.23 & 0.32 \\
\hline $15 \mathrm{H}-6,140-142$ & 139.61 & 2.43 & 0.38 \\
\hline $15 \mathrm{H}-7,20-22$ & 139.91 & 2.24 & 0.32 \\
\hline $15 \mathrm{H}-7,50-52$ & 140.21 & 2.83 & -0.07 \\
\hline $16 \mathrm{H}-1,22-26$ & 140.44 & 2.70 & 0.67 \\
\hline $16 \mathrm{H}-2,19-23$ & 141.91 & 3.27 & 0.08 \\
\hline $16 \mathrm{H}-2,28-42$ & 142.05 & 3.31 & 0.22 \\
\hline $16 \mathrm{H}-2,117-121$ & 142.89 & 2.71 & 0.66 \\
\hline $16 \mathrm{H}-3,3-7$ & 143.25 & 2.96 & 0.78 \\
\hline $16 \mathrm{H}-3,43-47$ & 143.65 & 2.83 & 0.19 \\
\hline $16 \mathrm{H}-3,64-67$ & 143.85 & 2.98 & 0.57 \\
\hline $16 \mathrm{H}-3,70-74$ & 143.92 & 3.48 & 0.28 \\
\hline $16 \mathrm{H}-3,80-82$ & 144.01 & 3.14 & -0.03 \\
\hline $16 \mathrm{H}-3,95-99$ & 144.17 & 2.54 & 0.69 \\
\hline $16 \mathrm{H}-3,110-112$ & 144.31 & 2.23 & 0.59 \\
\hline $16 \mathrm{H}-3,130-134$ & 144.52 & 2.58 & 0.69 \\
\hline $16 \mathrm{H}-3,144-146$ & 144.65 & 2.61 & 0.36 \\
\hline $16 \mathrm{H}-4,20-22$ & 144.91 & 2.74 & 0.57 \\
\hline $16 \mathrm{H}-4,50-52$ & 145.21 & 2.56 & 0.53 \\
\hline $16 \mathrm{H}-4,70-74$ & 145.42 & 2.88 & 0.70 \\
\hline $16 \mathrm{H}-4,80-82$ & 145.51 & 2.60 & 0.58 \\
\hline $16 \mathrm{H}-4,94-98$ & 145.66 & 2.56 & 0.88 \\
\hline $16 \mathrm{H}-4,110-112$ & 145.81 & 2.25 & 0.36 \\
\hline $16 \mathrm{H}-4,144-146$ & 146.15 & 3.18 & 0.15 \\
\hline $16 \mathrm{H}-5,20-22$ & 146.41 & 2.53 & 0.76 \\
\hline $16 \mathrm{H}-5,50-52$ & 146.71 & 2.19 & 0.69 \\
\hline $16 \mathrm{H}-5,70-74$ & 146.92 & 2.58 & 0.92 \\
\hline $16 \mathrm{H}-5,80-82$ & 147.01 & 2.32 & 0.42 \\
\hline $16 \mathrm{H}-5,110-112$ & 147.31 & 2.19 & 0.60 \\
\hline $16 \mathrm{H}-5,144-146$ & 147.65 & 2.54 & 0.73 \\
\hline $16 \mathrm{H}-6,20-22$ & 147.91 & 2.34 & 0.31 \\
\hline $16 \mathrm{H}-6,50-52$ & 148.21 & 2.99 & 0.28 \\
\hline $16 \mathrm{H}-6,70-74$ & 148.42 & 3.02 & 0.00 \\
\hline $17 \mathrm{X}-1,3-7$ & 149.75 & 3.10 & 0.19 \\
\hline $17 \mathrm{X}-1,20-22$ & 149.91 & 2.50 & 0.47 \\
\hline $17 X-1,36-40$ & 150.08 & 2.72 & 0.66 \\
\hline $17 X-1,50-52$ & 150.21 & 2.77 & 0.65 \\
\hline $17 X-1,63-67$ & 150.35 & 3.27 & 0.03 \\
\hline $17 X-1,70-74$ & 150.42 & 3.43 & 0.13 \\
\hline $17 X-1,80-82$ & 150.51 & 3.25 & -0.11 \\
\hline $17 X-1,93-97$ & 150.65 & 2.63 & 0.65 \\
\hline $17 \mathrm{X}-1,125-129$ & 150.97 & 2.63 & 0.63 \\
\hline $17 X-1,135-137$ & 151.07 & 2.53 & 0.63 \\
\hline $17 X-2,3-7$ & 151.25 & 2.70 & 0.70 \\
\hline $17 \mathrm{X}-2,20-22$ & 151.41 & 2.49 & 0.57 \\
\hline
\end{tabular}

Table 1 (continued).

\begin{tabular}{|c|c|c|c|}
\hline $\begin{array}{l}\text { Core, section, } \\
\text { interval }(\mathrm{cm})\end{array}$ & $\begin{array}{l}\text { Depth } \\
\text { (mbsf) }\end{array}$ & $\begin{array}{c}\delta^{18} \mathrm{O} \\
\left(\% \%_{\infty} \mathrm{PDB}\right)\end{array}$ & $\begin{array}{c}\delta^{13} \mathrm{C} \\
(\% \mathrm{PDB})\end{array}$ \\
\hline $17 X-2,33-37$ & 151.55 & 2.58 & 0.77 \\
\hline $17 X-2,50-52$ & 151.71 & 2.43 & 0.84 \\
\hline $17 X-2,63-67$ & 151.85 & 2.17 & 0.71 \\
\hline $17 \mathrm{X}-2,70-74$ & 151.92 & 2.59 & 0.63 \\
\hline $17 X-2,80-82$ & 152.01 & 2.58 & 0.56 \\
\hline $17 X-2,95-99$ & 152.17 & 2.84 & 0.52 \\
\hline $17 X-2,110-112$ & 152.31 & 2.97 & 0.23 \\
\hline $17 X-2,119-123$ & 152.41 & 2.96 & 0.41 \\
\hline $17 X-2,140-142$ & 152.61 & 2.48 & 0.92 \\
\hline $17 X-3,3-7$ & 152.75 & 2.49 & 1.25 \\
\hline $17 X-3,20-22$ & 152.91 & 2.96 & 0.72 \\
\hline $17 X-3,20-22$ & 152.91 & 2.55 & 0.59 \\
\hline $17 X-3,37-41$ & 153.09 & 2.40 & 0.99 \\
\hline $17 X-3,64-68$ & 153.36 & 2.75 & 1.11 \\
\hline $17 X-3,70-74$ & 153.42 & 3.15 & 0.95 \\
\hline $17 X-3,80-82$ & 153.51 & 2.71 & 0.82 \\
\hline $17 X-3,110-112$ & 153.81 & 2.92 & 0.50 \\
\hline $17 X-3,126-130$ & 153.98 & 2.83 & 0.94 \\
\hline $17 X-3,140-142$ & 154.11 & 2.46 & 0.76 \\
\hline $17 X-4,3-7$ & 154.25 & 2.56 & 0.93 \\
\hline $17 X-4,20-22$ & 154.41 & 2.34 & 0.69 \\
\hline $17 \times-4,50-52$ & 154.71 & 2.82 & 0.84 \\
\hline $17 X-4,63-67$ & 154.85 & 2.98 & 0.74 \\
\hline $17 X-4,70-74$ & 154.92 & 3.27 & 0.77 \\
\hline $17 X-4,80-82$ & 155.01 & 2.87 & 0.53 \\
\hline $17 X-4,110-112$ & 155.31 & 2.80 & 0.43 \\
\hline $17 X-4,126-130$ & 155.48 & 2.57 & 0.72 \\
\hline $17 X-4,140-142$ & 155.61 & 2.46 & 0.62 \\
\hline $17 X-5,20-22$ & 155.91 & 2.68 & 0.31 \\
\hline $17 X-5,33-37$ & 156.05 & 2.92 & 0.56 \\
\hline $17 X-5,50-52$ & 156.21 & 3.06 & 0.22 \\
\hline $17 X-5,63-67$ & 156.35 & 2.61 & 0.95 \\
\hline $17 X-5,70-74$ & 156.42 & 2.66 & 0.98 \\
\hline $17 X-5,80-82$ & 156.51 & 2.41 & 0.77 \\
\hline $17 X-5,96-100$ & 156.68 & 2.76 & 0.82 \\
\hline $17 X-5,110-112$ & 156.81 & 2.77 & 0.48 \\
\hline $17 X-5,127-131$ & 156.99 & 2.34 & 0.91 \\
\hline $17 X-5,140-142$ & 157.11 & 2.53 & 0.88 \\
\hline $17 X-6,3-7$ & 157.25 & 2.51 & 0.72 \\
\hline $17 X-6,20-22$ & 157.41 & 2.88 & 0.23 \\
\hline $17 \mathrm{X}-6,27-31$ & 157.49 & 3.05 & 0.55 \\
\hline $17 X-6,50-52$ & 157.71 & 2.51 & 0.57 \\
\hline $17 X-6,62-66$ & 157.84 & 2.87 & 0.77 \\
\hline $17 X-6,70-74$ & 157.92 & 2.79 & 0.76 \\
\hline $17 X-6,80-82$ & 158.01 & 2.59 & 0.59 \\
\hline $17 X-6,110-112$ & 158.31 & 2.73 & 0.90 \\
\hline $17 X-6,128-132$ & 158.50 & 2.40 & 0.92 \\
\hline $17 X-6,140-142$ & 158.61 & 2.17 & 0.65 \\
\hline $17 \mathrm{X}-\mathrm{CC}, 10-14$ & 158.82 & 2.56 & 0.64 \\
\hline $18 \mathrm{X}-1,20-22$ & 159.41 & 2.50 & 0.52 \\
\hline $18 \mathrm{X}-1,28-32$ & 159.50 & 2.68 & 0.66 \\
\hline $18 X-1,50-52$ & 159.71 & 2.91 & 0.45 \\
\hline $18 X-1,61-63$ & 159.82 & 2.81 & 0.75 \\
\hline $18 \mathrm{X}-1,70-74$ & 159.92 & 2.58 & 0.87 \\
\hline $18 X-1,76-78$ & 159.97 & 2.47 & 0.49 \\
\hline $18 X-1,96-100$ & 160.18 & 2.75 & 0.68 \\
\hline $18 \mathrm{X}-1,140-142$ & 160.61 & 2.70 & 0.33 \\
\hline $18 X-2,3-7$ & 160.75 & 2.43 & 0.81 \\
\hline $18 X-2,15-19$ & 160.87 & 2.59 & 0.88 \\
\hline $18 X-2,28-32$ & 161.00 & 2.79 & 0.68 \\
\hline $18 X-2,50-52$ & 161.21 & 2.81 & 0.66 \\
\hline
\end{tabular}


Table 1 (continued).

\begin{tabular}{|c|c|c|c|}
\hline $\begin{array}{l}\text { Core, section, } \\
\text { interval (cm) }\end{array}$ & $\begin{array}{l}\text { Depth } \\
\text { (mbsf) }\end{array}$ & $\begin{array}{c}\delta^{18} \mathrm{O} \\
(\% \text { PDB })\end{array}$ & $\begin{array}{c}\delta^{13} \mathrm{C} \\
(\% \text { PDB })\end{array}$ \\
\hline $18 X-2,61-65$ & 161.33 & 3.10 & 0.51 \\
\hline $18 X-2,70-74$ & 161.42 & 3.10 & 0.31 \\
\hline $18 X-2,76-78$ & 161.47 & 3.14 & 0.16 \\
\hline $18 X-2,86-90$ & 161.58 & 2.58 & 0.87 \\
\hline $18 X-2,110-112$ & 161.81 & 2.32 & 0.44 \\
\hline $18 X-2,125-129$ & 161.97 & 2.82 & 0.60 \\
\hline $18 X-2,140-142$ & 162.11 & 2.41 & 0.87 \\
\hline $18 X-3,1-5$ & 162.23 & 2.56 & 0.79 \\
\hline $18 X-3,20-22$ & 162.41 & 2.96 & 0.54 \\
\hline $18 \mathrm{X}-3,28-32$ & 162.50 & 2.95 & 0.68 \\
\hline $18 X-3,50-52$ & 162.71 & 2.76 & 0.53 \\
\hline $18 X-3,61-65$ & 162.83 & 2.83 & 0.70 \\
\hline $18 X-3,70-74$ & 162.92 & 3.04 & 0.73 \\
\hline $18 X-3,76-78$ & 162.97 & 2.87 & 0.52 \\
\hline $18 X-3,86-90$ & 163.08 & 2.75 & 0.63 \\
\hline $18 X-3,110-112$ & 163.31 & 2.95 & 0.46 \\
\hline $18 X-3,128-132$ & 163.50 & 2.68 & 0.72 \\
\hline $18 X-3,140-142$ & 163.61 & 2.83 & 0.57 \\
\hline $18 \times-4,3-7$ & 163.75 & 2.83 & 0.76 \\
\hline $18 X-4,20-22$ & 163.91 & 2.53 & 0.21 \\
\hline $18 X-4,32-36$ & 164.04 & 2.88 & 0.64 \\
\hline $18 \times-4,50-52$ & 164.21 & 3.15 & 1.07 \\
\hline $18 X-4,70-74$ & 164.42 & 2.69 & 1.15 \\
\hline $18 X-4,76-78$ & 164.47 & 2.55 & 0.98 \\
\hline $18 X-4,93-97$ & 164.65 & 2.92 & 1.18 \\
\hline $18 X-4,110-112$ & 164.81 & 3.01 & 0.88 \\
\hline $18 X-5,1-5$ & 165.23 & 2.58 & 1.37 \\
\hline $18 X-5,20-22$ & 165.41 & 2.40 & 1.26 \\
\hline $18 X-5,20-22$ & 165.41 & 2.36 & 1.22 \\
\hline $18 X-5,22-26$ & 165.44 & 2.63 & 1.27 \\
\hline $18 X-5,35-39$ & 165.57 & 2.56 & 1.15 \\
\hline $18 X-5,50-52$ & 165.71 & 2.61 & 1.06 \\
\hline $18 X-5,62-63$ & 165.82 & 2.80 & 0.92 \\
\hline $18 X-5,70-74$ & 165.92 & 2.98 & 0.83 \\
\hline $18 X-5,76-78$ & 165.97 & 2.91 & 0.17 \\
\hline $18 X-5,93-97$ & 166.15 & 3.07 & 0.88 \\
\hline $18 X-5,110-112$ & 166.31 & 2.79 & 0.93 \\
\hline $18 X-5,127-131$ & 166.49 & 2.63 & 1.03 \\
\hline $18 X-5,140-142$ & 166.61 & 2.60 & 0.91 \\
\hline $18 \times-6,3-7$ & 166.75 & 2.80 & 0.47 \\
\hline $18 X-6,28-32$ & 167.82 & 3.40 & 0.36 \\
\hline $18 X-6,20-22$ & 166.91 & 2.11 & 0.81 \\
\hline $18 X-6,50-52$ & 167.21 & 2.21 & 1.02 \\
\hline $18 X-6,68-70$ & 167.39 & 2.80 & -0.08 \\
\hline $18 X-6,70-74$ & 167.42 & 3.30 & 0.37 \\
\hline $18 X-6,88-92$ & 167.60 & 2.66 & 0.69 \\
\hline $18 X-6,110-112$ & 167.81 & 2.60 & 0.49 \\
\hline $18 \mathrm{X}-\mathrm{CC}$ & 168.28 & 2.77 & 0.58 \\
\hline $19 X-1,6-10$ & 168.78 & 2.89 & 0.90 \\
\hline $19 \mathrm{X}-1,20-22$ & 168.91 & 2.79 & 0.37 \\
\hline $19 X-1,33-37$ & 169.05 & 2.89 & 0.38 \\
\hline $19 X-1,50-52$ & 169.21 & 2.21 & 0.55 \\
\hline $19 X-1,60-62$ & 169.31 & 2.20 & 0.54 \\
\hline $19 X-1,75-77$ & 169.46 & 2.44 & 0.97 \\
\hline $19 X-1,87-91$ & 169.59 & 2.47 & 0.74 \\
\hline $19 X-1,110-112$ & 169.81 & 2.02 & 0.53 \\
\hline $19 X-1,124-128$ & 169.96 & 2.25 & 0.76 \\
\hline $19 X-1,140-142$ & 170.11 & 2.23 & 0.41 \\
\hline $19 X-1,143-147$ & 170.15 & 2.83 & 0.55 \\
\hline $19 X-2,1-5$ & 170.23 & 2.33 & 0.69 \\
\hline $19 X-2,20-22$ & 170.41 & 2.24 & 0.45 \\
\hline
\end{tabular}

Table 1 (continued).

\begin{tabular}{|c|c|c|c|}
\hline $\begin{array}{l}\text { Core, section, } \\
\text { interval }(\mathrm{cm})\end{array}$ & $\begin{array}{l}\text { Depth } \\
\text { (mbsf) }\end{array}$ & $\begin{array}{c}\delta^{18} \mathrm{O} \\
(\% \text { PDB })\end{array}$ & $\begin{array}{c}\delta^{13} \mathrm{C} \\
(\% \text { PDB })\end{array}$ \\
\hline $19 X-2,33-37$ & 170.55 & 2.19 & 0.74 \\
\hline $19 \mathrm{X}-2,46-50$ & 170.68 & 2.12 & 0.73 \\
\hline $19 X-2,50-52$ & 170.71 & 2.27 & 0.54 \\
\hline $19 X-2,60-62$ & 170.81 & 2.06 & 0.43 \\
\hline $19 X-2,76-80$ & 170.98 & 2.36 & 0.73 \\
\hline $19 X-2,93-97$ & 171.15 & 2.23 & 0.92 \\
\hline $19 X-2,110-112$ & 171.31 & 2.22 & 0.56 \\
\hline $19 \mathrm{X}-2,125-129$ & 171.47 & 2.18 & 0.92 \\
\hline $19 X-2,140-142$ & 171.61 & 2.11 & 0.69 \\
\hline $19 X-3,50-52$ & 172.21 & 2.63 & 1.15 \\
\hline $19 \mathrm{X}-3,62-66$ & 172.34 & 2.25 & 0.95 \\
\hline $19 X-3,82-86$ & 172.54 & 2.46 & 0.74 \\
\hline $19 X-3,94-98$ & 172.66 & 2.55 & 0.79 \\
\hline $19 X-3,112-116$ & 172.84 & 2.38 & 0.87 \\
\hline $19 X-3,128-132$ & 173.00 & 2.36 & 0.83 \\
\hline $19 X-3,140-142$ & 173.11 & 2.05 & 0.67 \\
\hline $19 X-4,1-5$ & 173.23 & 2.29 & 0.74 \\
\hline $19 \mathrm{X}-4,20-22$ & 173.41 & 1.85 & 0.34 \\
\hline $19 X-4,34-38$ & 173.56 & 2.57 & 0.65 \\
\hline $19 X-4,50-52$ & 173.71 & 1.87 & 0.45 \\
\hline $19 X-4,60-62$ & 173.81 & 1.54 & 0.46 \\
\hline $19 X-4,66-70$ & 173.88 & 2.17 & 1.08 \\
\hline $19 X-4,86-90$ & 174.08 & 2.41 & 1.12 \\
\hline $19 X-4,110-112$ & 174.31 & 2.34 & 0.51 \\
\hline $19 X-4,124-128$ & 174.46 & 2.75 & 0.74 \\
\hline $19 X-4,140-142$ & 174.61 & 2.04 & 0.60 \\
\hline $19 X-5,1-5$ & 174.73 & 2.44 & 0.83 \\
\hline $19 X-5,20-22$ & 174.91 & 2.29 & 0.33 \\
\hline $19 X-5,42-44$ & 175.13 & 2.70 & 0.68 \\
\hline $19 X-5,50-52$ & 175.21 & 2.53 & 0.29 \\
\hline $19 X-5,60-62$ & 175.31 & 2.69 & 0.34 \\
\hline $19 X-5,76-80$ & 175.48 & 2.74 & 0.55 \\
\hline $19 X-5,98-102$ & 175.71 & 2.83 & 0.43 \\
\hline $19 X-5,123-127$ & 175.95 & 2.25 & 0.64 \\
\hline $19 X-5,140-142$ & 176.11 & 2.30 & 0.40 \\
\hline $19 X-6,1-5$ & 176.23 & 2.39 & 0.79 \\
\hline $19 \mathrm{X}-6,20-22$ & 176.41 & 2.14 & 0.46 \\
\hline $19 \mathrm{X}-6,34-38$ & 176.56 & 2.47 & 0.85 \\
\hline $19 X-6,50-52$ & 176.71 & 2.19 & 0.93 \\
\hline $19 X-6,60-62$ & 176.81 & 1.98 & 0.71 \\
\hline $19 \mathrm{X}-6,74-78$ & 176.96 & 2.12 & 0.92 \\
\hline $19 X-6,93-97$ & 177.15 & 2.33 & 0.99 \\
\hline $19 \mathrm{X}-6,110-112$ & 177.31 & 2.23 & 0.54 \\
\hline $19 X-7,3-7$ & 177.75 & 2.38 & 0.63 \\
\hline $19 X-7,18-22$ & 177.90 & 2.29 & 0.45 \\
\hline $20 \mathrm{X}-1,2-6$ & 178.24 & 2.13 & 0.74 \\
\hline $20 \mathrm{X}-1,20-22$ & 178.41 & 1.89 & 0.38 \\
\hline $20 \mathrm{X}-1,20-22$ & 178.41 & 1.89 & 0.45 \\
\hline $20 X-1,27-31$ & 178.49 & 2.16 & 0.92 \\
\hline $20 \mathrm{X}-1,46-48$ & 178.67 & 1.90 & 0.79 \\
\hline $20 \mathrm{X}-1,62-66$ & 178.84 & 2.26 & 0.94 \\
\hline $20 \mathrm{X}-1,80-82$ & 179.01 & 1.89 & 0.64 \\
\hline $20 X-1,94-98$ & 179.16 & 2.11 & 0.92 \\
\hline $20 \mathrm{X}-1,110-112$ & 179.31 & 2.89 & 0.84 \\
\hline $20 X-1,123-127$ & 179.45 & 2.05 & 0.77 \\
\hline $20 X-1,140-142$ & 179.61 & 2.16 & 0.71 \\
\hline $20 \times-1,143-147$ & 179.65 & 2.42 & 0.91 \\
\hline $20 \times-2,3-7$ & 179.75 & 2.42 & 0.81 \\
\hline $20 \mathrm{X}-2,20-22$ & 179.91 & 2.31 & 1.04 \\
\hline $20 \times-2,33-37$ & 180.05 & 2.28 & 0.80 \\
\hline $20 X-2,46-48$ & 180.17 & 2.25 & 0.52 \\
\hline
\end{tabular}


Table 1 (continued).

\begin{tabular}{|c|c|c|c|}
\hline $\begin{array}{l}\text { Core, section, } \\
\text { interval }(\mathrm{cm})\end{array}$ & $\begin{array}{l}\text { Depth } \\
\text { (mbsf) }\end{array}$ & $\begin{array}{c}\delta^{18} \mathrm{O} \\
(\% \text { PDB })\end{array}$ & $\begin{array}{c}\delta^{13} \mathrm{C} \\
(\% \mathrm{PDB})\end{array}$ \\
\hline $20 X-2,63-67$ & 180.35 & 2.35 & 0.86 \\
\hline $20 X-2,80-82$ & 180.51 & 2.41 & 0.60 \\
\hline $20 \mathrm{X}-2,98-102$ & 180.70 & 2.24 & 0.78 \\
\hline $20 \times-2,123-127$ & 180.95 & 2.65 & 0.62 \\
\hline $20 X-2,143-144$ & 181.14 & 2.47 & 0.87 \\
\hline $20 \mathrm{X}-3,20-22$ & 181.41 & 2.27 & 0.54 \\
\hline $20 X-3,33-37$ & 181.55 & 2.43 & 0.89 \\
\hline $20 X-3,46-48$ & 181.67 & 2.16 & 0.69 \\
\hline $20 X-3,62-66$ & 181.84 & 2.17 & 0.84 \\
\hline $20 X-3,68-72$ & 181.90 & 2.18 & 0.77 \\
\hline $20 X-3,80-82$ & 182.01 & 2.22 & 0.73 \\
\hline $20 X-3,94-98$ & 182.16 & 2.21 & 1.03 \\
\hline $20 \mathrm{X}-3,110-112$ & 182.31 & 1.91 & 0.51 \\
\hline $20 X-3,3-7$ & 181.25 & 2.33 & 0.80 \\
\hline $20 \mathrm{X}-3,121-123$ & 182.42 & 2.25 & 0.67 \\
\hline $20 X-4,8-12$ & 182.80 & 2.76 & 0.74 \\
\hline $20 \mathrm{X}-4,28-32$ & 183.00 & 2.21 & 0.89 \\
\hline $20 \times-4,46-48$ & 183.17 & 2.06 & 0.80 \\
\hline $20 x-4,62-66$ & 183.34 & 1.95 & 0.77 \\
\hline $20 X-4,80-82$ & 183.51 & 1.90 & 0.45 \\
\hline $20 \times-4,95-99$ & 183.67 & 2.28 & 0.69 \\
\hline $20 \times-4,113-117$ & 183.85 & 1.92 & 0.80 \\
\hline $20 X-4,140-142$ & 184.11 & 2.32 & 0.52 \\
\hline $20 X-4,142-146$ & 184.14 & 1.74 & 0.71 \\
\hline $20 X-5,3-7$ & 184.25 & 1.92 & 0.85 \\
\hline $20 X-5,20-22$ & 184.41 & 1.95 & 0.59 \\
\hline $20 X-5,36-40$ & 184.58 & 1.97 & 0.65 \\
\hline $20 X-5,62-66$ & 184.84 & 2.31 & 1.07 \\
\hline $20 X-5,80-82$ & 185.01 & 1.82 & 0.60 \\
\hline $20 X-5,95-99$ & 185.17 & 1.74 & 0.80 \\
\hline $20 X-5,110-112$ & 185.31 & 1.92 & 0.83 \\
\hline $20 X-5,124-128$ & 185.46 & 2.08 & 0.87 \\
\hline $20 X-5,140-142$ & 185.61 & 2.50 & 0.81 \\
\hline $20 \times-6,3-7$ & 185.75 & 2.13 & 0.83 \\
\hline $20 X-6,22-26$ & 185.94 & 1.78 & 0.70 \\
\hline $20 X-6,42-44$ & 186.13 & 1.99 & 0.76 \\
\hline $20 X-6,62-66$ & 186.34 & 2.18 & 0.79 \\
\hline $20 X-6,80-82$ & 186.51 & 1.75 & 0.57 \\
\hline $20 \mathrm{X}-6,110-112$ & 186.81 & 1.40 & 0.66 \\
\hline $20 \times-6,140-142$ & 187.11 & 2.08 & 0.50 \\
\hline $20 \times-7,3-7$ & 187.25 & 1.88 & 0.90 \\
\hline $20 \times-7,20-22$ & 187.41 & 1.75 & 0.33 \\
\hline $21 X-1,28-32$ & 188.00 & 1.90 & 0.71 \\
\hline $21 X-1,44-46$ & 188.16 & 1.98 & 0.45 \\
\hline $21 X-1,44-46$ & 188.16 & 1.77 & 0.53 \\
\hline $21 X-1,110-112$ & 188.81 & 2.44 & 0.39 \\
\hline $21 X-2,45-47$ & 189.66 & 2.00 & 0.57 \\
\hline $21 X-2,110-112$ & 190.31 & 2.24 & 0.45 \\
\hline $21 X-3,45-47$ & 191.16 & 1.88 & 0.42 \\
\hline $21 X-3,80-82$ & 191.51 & 2.02 & 0.60 \\
\hline $21 X-3,110-112$ & 191.81 & 1.92 & 0.62 \\
\hline $21 X-4,28-32$ & 192.50 & 1.87 & 0.55 \\
\hline $21 X-4,45-47$ & 192.66 & 2.89 & 0.74 \\
\hline $22 X-1,20-22$ & 197.41 & 1.92 & 0.53 \\
\hline $22 X-1,110-112$ & 198.31 & 1.75 & 1.04 \\
\hline $23 X-1,110-112$ & 207.81 & 1.94 & 0.36 \\
\hline $23 X-1,140-142$ & 208.11 & 1.70 & 0.66 \\
\hline $23 X-2,20-22$ & 208.41 & 1.54 & 0.41 \\
\hline $23 X-2,80-82$ & 209.01 & 1.95 & 0.52 \\
\hline $23 X-2,110-112$ & 209.31 & 1.84 & 0.46 \\
\hline $23 X-2,140-142$ & 209.61 & 1.55 & 0.78 \\
\hline
\end{tabular}

Table 1 (continued).

\begin{tabular}{|c|c|c|c|}
\hline $\begin{array}{l}\text { Core, section, } \\
\text { interval }(\mathrm{cm})\end{array}$ & $\begin{array}{l}\text { Depth } \\
\text { (mbsf) }\end{array}$ & $\begin{array}{c}\delta^{18} \mathrm{O} \\
(\% \infty \mathrm{PDB})\end{array}$ & $\begin{array}{c}\delta^{13} \mathrm{C} \\
(\% \text { PDB })\end{array}$ \\
\hline $23 X-3,140-142$ & 211.11 & 1.74 & 0.80 \\
\hline $23 X-4,110-112$ & 212.31 & 1.37 & 0.23 \\
\hline $23 X-4,110-112$ & 212.31 & 1.89 & 0.69 \\
\hline $23 X-5,20-22$ & 212.91 & 1.65 & 0.76 \\
\hline $24 X-1,20-22$ & 216.41 & 1.59 & 0.64 \\
\hline $24 X-1,68-72$ & 216.90 & 2.27 & 0.87 \\
\hline $24 \mathrm{X}-1,88-90$ & 217.09 & 1.93 & 0.48 \\
\hline $24 \mathrm{X}-1,110-112$ & 217.31 & 1.80 & 0.66 \\
\hline $24 \mathrm{X}-1,140-142$ & 217.61 & 2.07 & 0.53 \\
\hline $24 X-2,110-112$ & 218.81 & 1.82 & 0.60 \\
\hline $24 X-4,68-72$ & 221.40 & 1.86 & 0.60 \\
\hline $24 X-4,140-142$ & 222.11 & 1.59 & 0.77 \\
\hline $24 X-5,20-22$ & 222.41 & 1.79 & 0.70 \\
\hline $24 X-5,88-90$ & 223.09 & 1.50 & 1.05 \\
\hline $25 \mathrm{X}-1,80-82$ & 226.51 & 1.43 & 0.56 \\
\hline $25 \mathrm{X}-1,110-112$ & 226.81 & 1.89 & 0.57 \\
\hline $25 X-4,110-112$ & 231.31 & 2.13 & 0.53 \\
\hline $25 X-6,20-22$ & 233.41 & 3.04 & -0.06 \\
\hline \multicolumn{4}{|l|}{ 114-704B- } \\
\hline $1 \mathrm{H}-1,30-32$ & 0.31 & 2.81 & 0.03 \\
\hline $1 \mathrm{H}-1,60-62$ & 0.61 & 3.00 & 0.19 \\
\hline $1 \mathrm{H}-1,89-91$ & 0.90 & 2.96 & 0.74 \\
\hline $1 \mathrm{H}-1,120-122$ & 1.21 & 2.64 & 0.59 \\
\hline $1 \mathrm{H}-2,30-32$ & 1.81 & 2.18 & 0.53 \\
\hline $1 \mathrm{H}-2,60-62$ & 2.11 & 2.27 & -0.17 \\
\hline $1 \mathrm{H}-2,89-91$ & 2.40 & 2.97 & 0.52 \\
\hline $1 \mathrm{H}-2,120-122$ & 2.71 & 2.66 & 0.73 \\
\hline $1 \mathrm{H}-2,150-152$ & 3.02 & 3.08 & 0.45 \\
\hline $1 \mathrm{H}-3,44-46$ & 3.45 & 2.53 & 0.57 \\
\hline $1 \mathrm{H}-4,73-75$ & 5.24 & 2.06 & 0.54 \\
\hline $1 \mathrm{H}-4,141-143$ & 5.92 & 2.25 & 1.04 \\
\hline $1 \mathrm{H}-5,19-21$ & 6.20 & 1.54 & 0.79 \\
\hline $1 \mathrm{H}-5,44-46$ & 6.45 & 1.58 & 1.09 \\
\hline $2 \mathrm{H}-1,7-9$ & 6.78 & 1.73 & 1.01 \\
\hline $2 \mathrm{H}-1,46-48$ & 7.13 & 2.83 & 0.91 \\
\hline $2 \mathrm{H}-1,107-109$ & 7.78 & 1.81 & 1.26 \\
\hline $2 \mathrm{H}-1,142-144$ & 8.13 & 3.58 & 0.43 \\
\hline $2 \mathrm{H}-2,60-62$ & 8.81 & 2.84 & 0.98 \\
\hline $2 \mathrm{H}-2,121-123$ & 9.42 & 2.99 & 1.01 \\
\hline $2 \mathrm{H}-2,150-152$ & 9.72 & 2.71 & 0.80 \\
\hline $2 \mathrm{H}-3,17-19$ & 9.88 & 2.94 & 0.77 \\
\hline $2 \mathrm{H}-3,61-63$ & 10.32 & 2.98 & 0.69 \\
\hline $2 \mathrm{H}-3,139-141$ & 11.10 & 2.76 & 0.93 \\
\hline $2 \mathrm{H}-4,16-18$ & 11.37 & 2.80 & 0.74 \\
\hline $2 \mathrm{H}-4,55-57$ & 11.76 & 2.71 & 0.86 \\
\hline $2 \mathrm{H}-4,98-100$ & 12.19 & 2.67 & 0.74 \\
\hline $2 \mathrm{H}-4,137-139$ & 12.58 & 3.30 & 0.26 \\
\hline $2 \mathrm{H}-5,14-16$ & 12.85 & 3.47 & 0.34 \\
\hline $2 \mathrm{H}-5,54-56$ & 13.25 & 3.41 & 0.18 \\
\hline $2 \mathrm{H}-5,96-98$ & 13.67 & 3.49 & 0.05 \\
\hline $2 \mathrm{H}-5,136-138$ & 14.07 & 3.19 & 0.00 \\
\hline $3 \mathrm{H}-1,21-23$ & 16.41 & 3.14 & 0.22 \\
\hline $3 \mathrm{H}-1,60-62$ & 16.81 & 3.31 & 0.37 \\
\hline $3 \mathrm{H}-1,95-97$ & 17.15 & 3.28 & 0.37 \\
\hline $3 \mathrm{H}-1,140-142$ & 17.61 & 3.31 & 0.44 \\
\hline $3 \mathrm{H}-2,21-23$ & 17.91 & 2.19 & 1.01 \\
\hline $3 \mathrm{H}-2,60-62$ & 18.31 & 2.06 & 0.98 \\
\hline $3 \mathrm{H}-2,95-97$ & 18.65 & 2.25 & 0.98 \\
\hline $3 \mathrm{H}-2,140-142$ & 19.11 & 2.19 & 1.02 \\
\hline $3 \mathrm{H}-3,21-23$ & 19.41 & 1.94 & 1.01 \\
\hline
\end{tabular}


Table 1 (continued).

\begin{tabular}{lccc}
\hline $\begin{array}{c}\text { Core, section, } \\
\text { interval (cm) }\end{array}$ & $\begin{array}{c}\text { Depth } \\
\text { (mbsf) }\end{array}$ & $\begin{array}{c}\delta^{18} \text { O } \\
\text { (\% } \% \text { PDB })\end{array}$ & $\begin{array}{c}\delta^{13} \text { C } \\
(\% \text { PDB })\end{array}$ \\
\hline $3 \mathrm{H}-3,60-62$ & 19.81 & 2.09 & 1.02 \\
$3 \mathrm{H}-3,95-97$ & 20.15 & 3.14 & 0.66 \\
$3 \mathrm{H}-3,140-142$ & 20.61 & 3.08 & 0.56 \\
$3 \mathrm{H}-4,20-22$ & 20.91 & 3.13 & 0.56 \\
$3 \mathrm{H}-4,20-22$ & 20.91 & 3.06 & 0.56 \\
$3 \mathrm{H}-4,44-46$ & 21.15 & 3.12 & 0.61 \\
$3 \mathrm{H}-4,60-62$ & 21.31 & 3.08 & 0.60 \\
$3 \mathrm{H}-4,140-142$ & 22.11 & 2.96 & 0.50 \\
$3 \mathrm{H}-4,140-142$ & 22.11 & 3.19 & 0.64 \\
$3 \mathrm{H}-5,21-23$ & 22.41 & 2.76 & 0.67 \\
$3 \mathrm{H}-5,60-62$ & 22.81 & 2.52 & 0.95 \\
$3 \mathrm{H}-5,95-97$ & 23.15 & 2.83 & 0.31 \\
$3 \mathrm{H}-5,140-142$ & 23.61 & 3.50 & 0.40 \\
$3 \mathrm{H}-6,21-23$ & 23.91 & 2.22 & 0.98 \\
$3 \mathrm{H}-6,60-62$ & 24.31 & 2.99 & 0.50 \\
$3 \mathrm{H}-6,95-95$ & 24.65 & 2.23 & 0.98 \\
$3 \mathrm{H}-6,140-142$ & 25.11 & 2.81 & 0.92 \\
$3 \mathrm{H}-7,21-23$ & 25.41 & 2.78 & 0.61 \\
$3 \mathrm{H}-7,60-62$ & 25.81 & 2.16 & 0.82 \\
$4 \mathrm{H}-1,31-33$ & 26.01 & 2.69 & 0.95 \\
$4 \mathrm{H}-1,70-72$ & 26.41 & 3.10 & 0.32 \\
$4 \mathrm{H}-1,105-107$ & 26.76 & 2.42 & 0.65 \\
$4 \mathrm{H}-1,120-122$ & 26.91 & 2.78 & 0.42 \\
$4 \mathrm{H}-1,145-147$ & 27.16 & 3.17 & 0.28 \\
$4 \mathrm{H}-2,31-33$ & 27.51 & 2.54 & 0.57 \\
$4 \mathrm{H}-2,70-72$ & 27.91 & 2.52 & 0.91 \\
$4 \mathrm{H}-2,105-107$ & 28.26 & 3.24 & 0.49 \\
$4 \mathrm{H}-2,120-122$ & 28.41 & 3.04 & 0.64 \\
$4 \mathrm{H}-2,145-147$ & 28.66 & 2.24 & 0.67 \\
$4 \mathrm{H}-3,31-33$ & 29.01 & 2.05 & 0.82 \\
$4 \mathrm{H}-3,70-72$ & 29.41 & 1.97 & 0.93 \\
$4 \mathrm{H}-3,105-107$ & 29.76 & 3.16 & 1.05 \\
$4 \mathrm{H}-3,145-147$ & 30.16 & 2.59 & 0.55 \\
$4 \mathrm{H}-4,31-33$ & 30.51 & 2.85 & 0.60 \\
$4 \mathrm{H}-4,70-72$ & 30.91 & 2.68 & 0.61 \\
$4 \mathrm{H}-4,105-107$ & 31.26 & 2.76 & 0.67 \\
$4 \mathrm{H}-4,120-122$ & 31.41 & 2.67 & 0.46 \\
$4 \mathrm{H}-4,145-147$ & 31.66 & 2.74 & 0.55 \\
$4 \mathrm{H}-5,31-33$ & 32.01 & 3.31 & 0.05
\end{tabular}

Table 1 (continued).

\begin{tabular}{lccc}
\hline \multicolumn{1}{c}{$\begin{array}{c}\text { Core, section, } \\
\text { interval (cm) }\end{array}$} & $\begin{array}{c}\text { Depth } \\
\text { (mbsf) }\end{array}$ & $\begin{array}{c}\delta^{18} \text { O } \\
\left(\%{ }_{\infty} \text { PDB }\right)\end{array}$ & $\begin{array}{c}\delta^{13} \mathrm{C} \\
\left(\%{ }_{\infty} \text { PDB }\right)\end{array}$ \\
\hline $4 \mathrm{H}-5,38-42$ & 32.10 & 2.47 & 0.57 \\
$4 \mathrm{H}-5,70-72$ & 32.41 & 2.88 & 0.64 \\
$4 \mathrm{H}-5,105-107$ & 32.76 & 3.17 & 0.36 \\
$4 \mathrm{H}-5,120-122$ & 32.91 & 3.79 & 0.51 \\
$4 \mathrm{H}-5,145-147$ & 33.16 & 2.86 & 0.16 \\
$4 \mathrm{H}-6,31-33$ & 33.51 & 2.66 & 0.50 \\
$4 \mathrm{H}-6,70-72$ & 33.91 & 2.64 & 0.78 \\
$4 \mathrm{H}-6,105-107$ & 34.26 & 2.34 & 0.73 \\
$5 \mathrm{H}-1,16-18$ & 35.36 & 2.30 & 0.59 \\
$5 \mathrm{H}-1,20-22$ & 35.41 & 2.28 & 0.58 \\
$5 \mathrm{H}-1,50-52$ & 35.71 & 2.30 & 0.65 \\
$5 \mathrm{H}-1,72-74$ & 35.94 & 2.90 & 0.17 \\
$5 \mathrm{H}-1,94-96$ & 36.14 & 2.40 & 0.43 \\
$5 \mathrm{H}-1,121-123$ & 36.41 & 2.51 & 0.41 \\
$5 \mathrm{H}-1,125-127$ & 36.46 & 2.65 & 0.49 \\
$5 \mathrm{H}-2,18-20$ & 36.88 & 2.48 & 0.56 \\
$5 \mathrm{H}-2,18-20$ & 36.88 & 2.49 & 0.53 \\
$5 \mathrm{H}-2,51-52$ & 37.21 & 2.56 & 0.68 \\
$5 \mathrm{H}-2,94-96$ & 37.64 & 2.40 & 0.42 \\
$5 \mathrm{H}-2,125-127$ & 37.96 & 2.33 & 0.78 \\
$5 \mathrm{H}-2,15-17$ & 38.36 & 2.10 & 0.59 \\
$5 \mathrm{H}-3,51-52$ & 38.71 & 2.67 & 0.03 \\
$5 \mathrm{H}-3,94-96$ & 39.14 & 2.88 & 0.54 \\
$5 \mathrm{H}-3,125-127$ & 39.46 & 2.72 & 0.20 \\
$5 \mathrm{H}-4,16-18$ & 39.86 & 2.44 & 0.76 \\
$5 \mathrm{H}-4,51-52$ & 40.21 & 1.92 & 0.84 \\
$5 \mathrm{H}-4,94-96$ & 40.64 & 2.87 & 0.88 \\
$5 \mathrm{H}-4,125-127$ & 40.96 & 2.57 & 0.84 \\
$5 \mathrm{H}-5,16-18$ & 41.36 & 2.72 & 0.90 \\
$5 \mathrm{H}-5,51-52$ & 41.71 & 2.92 & 0.97 \\
$5 \mathrm{H}-5,94-96$ & 42.14 & 2.57 & 1.09 \\
$5 \mathrm{H}-5,125-127$ & 42.46 & 2.73 & 0.76 \\
$5 \mathrm{H}-6,16-18$ & 42.86 & 3.36 & 0.66 \\
$5 \mathrm{H}-6,16-18$ & 42.86 & 3.21 & 0.61 \\
$5 \mathrm{H}-6,51-52$ & 43.21 & 3.38 & 0.57 \\
$5 \mathrm{H}-6,94-96$ & 43.64 & 3.41 & 0.48 \\
$5 \mathrm{H}-6,125-127$ & 43.96 & 3.06 & 0.59 \\
$5 \mathrm{H}-7,16-18$ & 44.36 & 2.20 & 1.10 \\
$5 \mathrm{H}-7,20-22$ & 44.41 & 3.40 & 0.45 \\
\hline & & &
\end{tabular}


Table 2. Oxygen and carbon isotopic results of mixed samples of the benthic foraminifers Planulina wuellerstorfi, Cibicidoides kullenbergi, and Cibicidoides spp. from ODP Site 704.

\begin{tabular}{|c|c|c|c|c|c|c|c|}
\hline $\begin{array}{l}\text { Core, section, } \\
\text { interval }(\mathrm{cm})\end{array}$ & $\begin{array}{l}\text { Depth } \\
\text { (mbsf) }\end{array}$ & $\begin{array}{c}\delta^{18} \mathrm{O} \\
(\% \circ \mathrm{PDB})\end{array}$ & $\begin{array}{c}\delta^{13} \mathrm{O} \\
(\% \text { PDB })\end{array}$ & $\begin{array}{l}\text { Core, section, } \\
\text { interval }(\mathrm{cm})\end{array}$ & $\begin{array}{l}\text { Depth } \\
\text { (mbsf) }\end{array}$ & $\begin{array}{c}\delta^{18} \mathrm{O} \\
(\% \text { PDB })\end{array}$ & $\begin{array}{c}\delta^{13} \mathrm{O} \\
(\% \text { PDB })\end{array}$ \\
\hline $114-704 \mathrm{~A}-$ & & & & $6 \mathrm{H}-2,80-82$ & 47.61 & 3.34 & -0.56 \\
\hline $1 \mathrm{H}-2,76-80$ & 2.28 & 2.64 & 0.37 & $6 \mathrm{H}-2,105-107$ & 47.76 & 2.76 & -0.26 \\
\hline $1 \mathrm{H}-2,108-112$ & 2.60 & 2.27 & -0.23 & $6 \mathrm{H}-2,120-124$ & 47.90 & 2.69 & -0.38 \\
\hline $1 \mathrm{H}-2,108-112$ & 2.60 & 2.36 & -0.17 & $6 \mathrm{H}-2,130-134$ & 48.02 & 3.32 & 0.22 \\
\hline $1 \mathrm{H}-2,108-112$ & 2.60 & 2.79 & 0.20 & $6 \mathrm{H}-2,140-142$ & 48.11 & 3.33 & 0.02 \\
\hline $1 \mathrm{H}-2,130-134$ & 2.82 & 2.67 & 0.24 & $6 \mathrm{H}-3,4-6$ & 48.25 & 2.67 & -0.23 \\
\hline $1 \mathrm{H}-3,130-134$ & 4.32 & 2.82 & 0.39 & $6 \mathrm{H}-3,19-21$ & 48.40 & 2.78 & -0.32 \\
\hline $1 \mathrm{H}-4,40-42$ & 4.91 & 2.81 & 0.66 & $6 \mathrm{H}-3,54-56$ & 48.75 & 2.76 & -0.17 \\
\hline $1 \mathrm{H}-4,76-80$ & 5.28 & 3.49 & -0.49 & $6 \mathrm{H}-3,54-56$ & 48.75 & 3.03 & -0.19 \\
\hline $1 \mathrm{H}-4,108-112$ & 5.60 & 2.86 & 0.72 & $6 \mathrm{H}-3,84-86$ & 49.05 & 4.04 & -0.78 \\
\hline $1 \mathrm{H}-4,123-127$ & 5.75 & 2.58 & 0.75 & $6 \mathrm{H}-3,105-107$ & 49.26 & 4.14 & -0.92 \\
\hline $1 \mathrm{H}-4,130-134$ & 5.82 & 2.60 & 0.82 & $6 \mathrm{H}-4,19-21$ & 49.90 & 3.47 & -1.47 \\
\hline $1 \mathrm{H}-5,19-23$ & 6.20 & 2.78 & 0.53 & $6 \mathrm{H}-4,54-56$ & 50.25 & 4.00 & -0.87 \\
\hline $1 \mathrm{H}-5,60-64$ & 6.62 & 2.59 & 0.77 & $6 \mathrm{H}-4,84-86$ & 50.55 & 3.46 & -1.52 \\
\hline $1 \mathrm{H}-5,76-80$ & 6.78 & 3.23 & 0.08 & $6 \mathrm{H}-4,84-86$ & 50.55 & 4.06 & -1.08 \\
\hline $2 \mathrm{H}-1,40-42$ & 7.61 & 2.54 & 0.57 & $6 \mathrm{H}-4,105-107$ & 50.76 & 3.97 & -0.96 \\
\hline $2 \mathrm{H}-1,62-64$ & 7.83 & 2.46 & 0.77 & $6 \mathrm{H}-4,105-107$ & 50.76 & 3.83 & -0.75 \\
\hline $2 \mathrm{H}-1,80-84$ & 8.02 & 2.68 & 0.26 & $6 \mathrm{H}-4,130-134$ & 51.02 & 3.92 & -0.81 \\
\hline $1 \mathrm{H}-6,130-134$ & 8.82 & 4.03 & -0.45 & $6 \mathrm{H}-4,140-142$ & 51.11 & 3.94 & -0.79 \\
\hline $2 \mathrm{H}-6,60-64$ & 15.32 & 4.13 & -0.39 & $6 \mathrm{H}-4,140-142$ & 51.11 & 3.63 & -1.15 \\
\hline $3 \mathrm{H}-1,26-30$ & 16.98 & 3.66 & -1.15 & $6 \mathrm{H}-5,19-21$ & 51.40 & 2.87 & -0.05 \\
\hline $3 \mathrm{H}-1,80-84$ & 17.52 & 3.03 & -1.04 & $6 \mathrm{H}-5,54-56$ & 51.75 & 2.70 & -0.16 \\
\hline $3 \mathrm{H}-1,90-94$ & 17.62 & 3.10 & -0.43 & $6 \mathrm{H}-5,84-86$ & 52.05 & 3.86 & -0.95 \\
\hline $3 \mathrm{H}-1,115-117$ & 17.86 & 3.08 & 0.08 & $6 \mathrm{H}-5,105-107$ & 52.26 & 3.32 & -1.37 \\
\hline $3 \mathrm{H}-2,26-30$ & 18.48 & 2.98 & 0.01 & $6 \mathrm{H}-5,130-134$ & 52.52 & 3.60 & -0.77 \\
\hline $3 \mathrm{H}-2,90-94$ & 19.12 & 2.89 & 0.14 & $6 \mathrm{H}-5,140-142$ & 52.61 & 3.34 & -0.76 \\
\hline $3 \mathrm{H}-3,26-30$ & 19.98 & 3.06 & 0.24 & $6 \mathrm{H}-5,140-142$ & 52.61 & 3.22 & -0.95 \\
\hline $3 \mathrm{H}-3,90-94$ & 20.62 & 3.45 & -0.76 & $6 \mathrm{H}-5,140-142$ & 52.61 & 3.36 & -0.96 \\
\hline $3 \mathrm{H}-3,115-117$ & 20.86 & 3.02 & -0.32 & $6 \mathrm{H}-6,19-21$ & 52.90 & 3.51 & -0.25 \\
\hline $3 \mathrm{H}-4,26-30$ & 21.48 & 3.30 & -0.67 & $6 \mathrm{H}-6,54-56$ & 53.25 & 3.34 & -0.14 \\
\hline $3 \mathrm{H}-4,80-84$ & 22.02 & 4.12 & -0.39 & $6 \mathrm{H}-6,84-86$ & 53.55 & 2.82 & -0.15 \\
\hline $3 \mathrm{H}-4,80-84$ & 22.02 & 3.35 & -0.67 & $6 \mathrm{H}-6,105-107$ & 53.78 & 3.18 & -0.50 \\
\hline $3 \mathrm{H}-4,90-94$ & 22.12 & 3.49 & -0.52 & $6 \mathrm{H}-6,130-134$ & 54.02 & 2.92 & 0.04 \\
\hline $3 \mathrm{H}-4,115-117$ & 22.36 & 3.54 & -0.45 & $6 \mathrm{H}-6,140-142$ & 54.11 & 3.30 & -0.32 \\
\hline $3 \mathrm{H}-5,74-78$ & 23.46 & 3.42 & -0.71 & $6 \mathrm{H}-7,54-56$ & 54.75 & 2.97 & 0.08 \\
\hline $3 \mathrm{H}-5,80-84$ & 23.52 & 3.17 & -0.67 & $7 \mathrm{H}-1,59-61$ & 55.30 & 3.60 & -0.86 \\
\hline $3 \mathrm{H}-6,26-30$ & 24.48 & 3.12 & -0.32 & $7 \mathrm{H}-1,90-92$ & 55.61 & 3.60 & -0.57 \\
\hline $3 \mathrm{H}-6,40-44$ & 24.62 & 3.17 & -0.27 & $7 \mathrm{H}-1,119-121$ & 55.90 & 3.40 & -0.57 \\
\hline $3 \mathrm{H}-6,74-78$ & 24.96 & 3.59 & 0.37 & $7 \mathrm{H}-2,10-12$ & 56.31 & 3.48 & -0.92 \\
\hline $3 \mathrm{H}-6,80-84$ & 25.02 & 3.17 & -0.27 & $7 \mathrm{H}-2,10-12$ & 56.31 & 3.14 & -0.94 \\
\hline $3 \mathrm{H}-6,90-94$ & 25.12 & 3.41 & -0.06 & $7 \mathrm{H}-2,29-31$ & 56.50 & 3.18 & -0.13 \\
\hline $4 \mathrm{H}-2,70-72$ & 28.41 & 2.35 & -0.03 & $7 \mathrm{H}-2,29-31$ & 56.50 & 3.41 & -0.40 \\
\hline $4 \mathrm{H}-3,30-32$ & 31.01 & 3.18 & -0.42 & $7 \mathrm{H}-2,29-31$ & 56.50 & 3.72 & -0.90 \\
\hline $5 \mathrm{H}-1,20-22$ & 35.91 & 3.06 & 0.34 & $7 \mathrm{H}-2,29-31$ & 56.50 & 3.89 & -0.94 \\
\hline $5 \mathrm{H}-1,20-22$ & 35.91 & 3.19 & -0.41 & $7 \mathrm{H}-2,59-61$ & 56.80 & 3.46 & -0.61 \\
\hline $5 \mathrm{H}-1,80-82$ & 36.51 & 3.02 & -0.62 & $7 \mathrm{H}-2,59-61$ & 56.80 & 3.50 & -0.79 \\
\hline $5 \mathrm{H}-2,20-22$ & 37.41 & 3.25 & -0.09 & $7 \mathrm{H}-2,59-61$ & 56.80 & 3.60 & -0.67 \\
\hline $5 \mathrm{H}-5,70-74$ & 42.42 & 3.29 & -0.43 & $7 \mathrm{H}-2,90-92$ & 57.11 & 3.33 & -0.48 \\
\hline $5 \mathrm{H}-6,19-23$ & 43.41 & 3.02 & -0.51 & $7 \mathrm{H}-2,90-92$ & 57.11 & 3.47 & -0.52 \\
\hline $6 \mathrm{H}-1,54-56$ & 45.75 & 3.17 & -0.01 & $7 \mathrm{H}-2,90-92$ & 57.11 & 3.38 & -0.34 \\
\hline $6 \mathrm{H}-1,54-56$ & 45.75 & 3.17 & 0.00 & $7 \mathrm{H}-2,119-121$ & 57.40 & 3.09 & 0.13 \\
\hline $6 \mathrm{H}-1,84-86$ & 46.05 & 2.91 & -0.13 & $7 \mathrm{H}-2,119-121$ & 57.40 & 2.80 & -0.13 \\
\hline $6 \mathrm{H}-1,84-86$ & 46.05 & 3.04 & 0.30 & $7 \mathrm{H}-2,119-121$ & 57.74 & 3.12 & 0.59 \\
\hline $6 \mathrm{H}-1,105-107$ & 46.26 & 3.45 & 0.01 & $7 \mathrm{H}-3,10-12$ & 57.81 & 3.12 & 0.29 \\
\hline $6 \mathrm{H}-1,130-134$ & 46.52 & 3.00 & 0.51 & $7 \mathrm{H}-3,10-12$ & 57.81 & 3.34 & 0.18 \\
\hline $6 \mathrm{H}-1,140-142$ & 46.61 & 2.39 & 0.35 & $7 \mathrm{H}-3,29-31$ & 58.00 & 3.11 & 0.04 \\
\hline $6 \mathrm{H}-2,4-6$ & 46.75 & 2.88 & -0.89 & $7 \mathrm{H}-3,29-31$ & 58.00 & 3.12 & 0.11 \\
\hline $6 \mathrm{H}-2,19-21$ & 46.90 & 3.51 & -0.25 & $7 \mathrm{H}-3,29-31$ & 58.00 & 3.17 & 0.12 \\
\hline $6 \mathrm{H}-2,19-21$ & 46.90 & 3.42 & -0.35 & $7 \mathrm{H}-3,59-61$ & 58.30 & 3.41 & -0.16 \\
\hline $6 \mathrm{H}-2,54-56$ & 47.25 & 2.97 & -0.83 & $7 \mathrm{H}-3,59-61$ & 58.30 & 3.64 & -0.08 \\
\hline
\end{tabular}


Table 2 (continued).

\begin{tabular}{|c|c|c|c|}
\hline $\begin{array}{l}\text { Core, section, } \\
\text { interval }(\mathrm{cm})\end{array}$ & $\begin{array}{l}\text { Depth } \\
\text { (mbsf) }\end{array}$ & $\begin{array}{c}\delta^{18} \mathrm{O} \\
(\% \text { PDB })\end{array}$ & $\begin{array}{c}\delta^{13} \mathrm{O} \\
\left(\%{ }_{o} \mathrm{PDB}\right)\end{array}$ \\
\hline $7 \mathrm{H}-3,59-61$ & 58.30 & 3.57 & -0.60 \\
\hline $7 \mathrm{H}-3,59-61$ & 58.30 & 3.67 & -0.16 \\
\hline $7 \mathrm{H}-3,90-92$ & 58.61 & 3.55 & -0.97 \\
\hline $7 \mathrm{H}-3,119-121$ & 58.90 & 3.74 & -1.25 \\
\hline $7 \mathrm{H}-4,2-6$ & 59.24 & 3.73 & -0.83 \\
\hline $7 \mathrm{H}-4,10-12$ & 59.31 & 3.48 & -0.81 \\
\hline $7 \mathrm{H}-4,30-32$ & 59.50 & 3.79 & -0.40 \\
\hline $7 \mathrm{H}-4,30-32$ & 59.50 & 3.54 & -0.46 \\
\hline $7 \mathrm{H}-4,59-61$ & 59.80 & 3.11 & -0.37 \\
\hline $7 \mathrm{H}-4,59-61$ & 59.80 & 3.11 & -0.38 \\
\hline $7 \mathrm{H}-4,90-92$ & 60.11 & 2.98 & 0.25 \\
\hline $7 \mathrm{H}-4,119-121$ & 60.40 & 2.98 & 0.13 \\
\hline $7 \mathrm{H}-4,119-121$ & 60.40 & 3.21 & 0.34 \\
\hline $7 \mathrm{H}-5,10-12$ & 60.81 & 2.92 & 0.28 \\
\hline $7 \mathrm{H}-5,10-12$ & 60.81 & 3.07 & 0.48 \\
\hline $7 \mathrm{H}-5,29-31$ & 61.00 & 3.39 & 0.34 \\
\hline $7 \mathrm{H}-5,90-92$ & 61.61 & 3.68 & -0.83 \\
\hline $7 \mathrm{H}-5,119-121$ & 61.90 & 3.88 & -0.73 \\
\hline $7 \mathrm{H}-6,2-6$ & 62.24 & 3.75 & -0.73 \\
\hline $7 \mathrm{H}-6,10-12$ & 62.31 & 3.55 & -0.95 \\
\hline $7 \mathrm{H}-6,29-31$ & 62.50 & 3.62 & -1.01 \\
\hline $7 \mathrm{H}-6,50-52$ & 62.71 & 3.51 & -0.78 \\
\hline $7 \mathrm{H}-6,90-92$ & 63.11 & 3.37 & -0.31 \\
\hline $7 \mathrm{H}-6,90-92$ & 63.11 & 3.69 & -0.14 \\
\hline $7 \mathrm{H}-7,2-6$ & 63.74 & 3.80 & -0.85 \\
\hline $8 \mathrm{H}-1,29-31$ & 64.50 & 2.59 & 0.27 \\
\hline $8 \mathrm{H}-1,47-51$ & 64.69 & 3.52 & -0.04 \\
\hline $8 \mathrm{H}-1,67-69$ & 64.88 & 3.44 & -0.09 \\
\hline $8 H-1,92-96$ & 65.14 & 3.08 & 0.31 \\
\hline $8 \mathrm{H}-1,110-112$ & 65.31 & 2.68 & 0.21 \\
\hline $8 \mathrm{H}-1,123-125$ & 65.44 & 3.97 & -0.83 \\
\hline $8 \mathrm{H}-2,5-9$ & 65.77 & 3.53 & -0.57 \\
\hline $8 \mathrm{H}-2,29-31$ & 66.00 & 3.34 & -1.11 \\
\hline $8 \mathrm{H}-2,40-44$ & 66.12 & 3.92 & -1.03 \\
\hline $8 \mathrm{H}-2,64-68$ & 66.36 & 3.80 & -0.82 \\
\hline $8 \mathrm{H}-2,84-88$ & 66.56 & 3.60 & -0.19 \\
\hline $8 \mathrm{H}-2,110-112$ & 66.81 & 3.16 & 0.09 \\
\hline $8 \mathrm{H}-2,124-126$ & 66.95 & 3.27 & 0.16 \\
\hline $8 \mathrm{H}-3,47-49$ & 67.68 & 3.10 & -0.41 \\
\hline $8 \mathrm{H}-3,65-69$ & 67.87 & 4.02 & -0.88 \\
\hline $8 \mathrm{H}-3,92-96$ & 68.14 & 4.26 & -0.61 \\
\hline $8 \mathrm{H}-3,110-112$ & 68.31 & 3.38 & -0.80 \\
\hline $8 \mathrm{H}-3,124-126$ & 68.45 & 2.93 & -0.76 \\
\hline $8 \mathrm{H}-3,139-141$ & 68.60 & 3.66 & -0.60 \\
\hline $8 \mathrm{H}-4,5-9$ & 68.77 & 3.56 & -0.20 \\
\hline $8 \mathrm{H}-4,100-102$ & 69.71 & 3.85 & -0.45 \\
\hline $8 \mathrm{H}-4,110-112$ & 69.81 & 3.61 & -0.60 \\
\hline $8 \mathrm{H}-4,124-126$ & 69.95 & 4.13 & -0.93 \\
\hline $8 \mathrm{H}-5,5-9$ & 70.27 & 3.96 & -1.23 \\
\hline $8 \mathrm{H}-5,16-19$ & 70.37 & 4.07 & -0.98 \\
\hline $8 \mathrm{H}-5,64-68$ & 70.86 & 3.93 & -0.24 \\
\hline $8 \mathrm{H}-5,90-92$ & 71.11 & 3.77 & -0.53 \\
\hline $8 \mathrm{H}-5,121-125$ & 71.43 & 3.47 & -0.12 \\
\hline $8 H-6,14-18$ & 71.86 & 3.81 & -0.29 \\
\hline $8 \mathrm{H}-6,39-43$ & 72.11 & 3.48 & 0.01 \\
\hline $8 \mathrm{H}-6,120-124$ & 72.92 & 3.65 & -0.37 \\
\hline $8 \mathrm{H}-\mathrm{CC}, 8-12$ & 73.30 & 3.88 & -0.49 \\
\hline $9 \mathrm{H}-1,34-38$ & 74.06 & 3.55 & -0.17 \\
\hline $9 \mathrm{H}-1,98-101$ & 74.70 & 3.30 & 0.03 \\
\hline $9 \mathrm{H}-2,35-39$ & 75.57 & 3.43 & 0.00 \\
\hline
\end{tabular}

Table 2 (continued).

\begin{tabular}{|c|c|c|c|}
\hline $\begin{array}{l}\text { Core, section, } \\
\text { interval }(\mathrm{cm})\end{array}$ & $\begin{array}{l}\text { Depth } \\
\text { (mbsf) }\end{array}$ & $\begin{array}{c}\delta^{18} \mathrm{O} \\
\left(\%{ }_{\infty} \mathrm{PDB}\right)\end{array}$ & $\begin{array}{c}\delta^{13} \mathrm{O} \\
(\% \text { PDB })\end{array}$ \\
\hline $9 \mathrm{H}-3,123-127$ & 77.95 & 3.78 & -0.24 \\
\hline $9 \mathrm{H}-4,3-7$ & 78.25 & 3.58 & -0.13 \\
\hline $9 \mathrm{H}-4,33-37$ & 78.55 & 3.52 & 0.09 \\
\hline $9 H-4,97-99$ & 79.18 & 3.36 & 0.12 \\
\hline $9 \mathrm{H}-5,3-7$ & 79.75 & 3.85 & -0.12 \\
\hline $9 \mathrm{H}-5,33-37$ & 80.05 & 4.12 & -0.41 \\
\hline $9 \mathrm{H}-5,128-132$ & 81.00 & 4.12 & -0.37 \\
\hline $9 \mathrm{H}-6,34-38$ & 81.56 & 3.96 & -0.65 \\
\hline $9 \mathrm{H}-6,63-67$ & 81.85 & 4.20 & -0.65 \\
\hline $9 \mathrm{H}-7,3-7$ & 82.75 & 4.09 & -0.89 \\
\hline $10 \mathrm{H}-1,3-7$ & 83.25 & 4.00 & -0.45 \\
\hline $10 \mathrm{H}-1,32-36$ & 83.54 & 3.80 & -0.75 \\
\hline $10 \mathrm{H}-1,62-66$ & 83.84 & 3.88 & -0.79 \\
\hline $10 \mathrm{H}-1,132-136$ & 84.54 & 3.81 & -0.63 \\
\hline $10 \mathrm{H}-2,3-7$ & 84.75 & 3.64 & -0.59 \\
\hline $10 \mathrm{H}-2,33-37$ & 85.05 & 3.36 & -0.15 \\
\hline $10 \mathrm{H}-2,63-67$ & 85.35 & 3.52 & -0.32 \\
\hline $10 \mathrm{H}-2,92-96$ & 85.64 & 3.47 & -0.26 \\
\hline $10 \mathrm{H}-2,142-145$ & 86.14 & 3.74 & -0.78 \\
\hline $10 \mathrm{H}-3,3-7$ & 86.25 & 3.47 & -0.72 \\
\hline $10 \mathrm{H}-3,32-36$ & 86.54 & 3.69 & -0.78 \\
\hline $10 \mathrm{H}-3,63-67$ & 86.85 & 3.81 & -0.51 \\
\hline $10 \mathrm{H}-3,95-97$ & 87.17 & 3.55 & -0.66 \\
\hline $10 \mathrm{H}-3,124-128$ & 87.46 & 3.64 & -0.59 \\
\hline $10 \mathrm{H}-3,143-147$ & 87.65 & 3.80 & -0.48 \\
\hline $10 \mathrm{H}-4,3-7$ & 87.75 & 3.51 & -0.80 \\
\hline $10 \mathrm{H}-4,33-37$ & 88.05 & 4.11 & -0.80 \\
\hline $10 \mathrm{H}-4,62-66$ & 88.34 & 3.85 & -0.54 \\
\hline $10 \mathrm{H}-4,92-96$ & 88.64 & 3.65 & -0.71 \\
\hline $10 \mathrm{H}-4,123-127$ & 88.95 & 3.62 & -0.90 \\
\hline $10 \mathrm{H}-4,142-146$ & 89.14 & 3.81 & -0.83 \\
\hline $10 \mathrm{H}-5,3-7$ & 89.25 & 3.95 & -0.74 \\
\hline $10 \mathrm{H}-5,28-32$ & 89.50 & 3.97 & -0.81 \\
\hline $10 \mathrm{H}-5,58-62$ & 89.80 & 3.86 & -1.03 \\
\hline $10 \mathrm{H}-5,123-127$ & 90.45 & 3.56 & -0.74 \\
\hline $10 \mathrm{H}-5,140-144$ & 90.62 & 3.70 & -0.71 \\
\hline $10 \mathrm{H}-6,3-7$ & 90.75 & 3.39 & -0.85 \\
\hline $10 \mathrm{H}-6,3-7$ & 90.75 & 3.67 & -0.60 \\
\hline $10 \mathrm{H}-6,28-32$ & 91.00 & 3.64 & -0.76 \\
\hline $10 \mathrm{H}-6,63-67$ & 91.35 & 3.59 & -0.63 \\
\hline $10 \mathrm{H}-6,63-67$ & 91.35 & 3.53 & -0.79 \\
\hline $10 \mathrm{H}-6,93-97$ & 91.65 & 3.66 & -0.57 \\
\hline $10 \mathrm{H}-6,93-97$ & 91.65 & 3.51 & -0.83 \\
\hline $10 \mathrm{H}-6,133-137$ & 92.05 & 3.62 & -0.85 \\
\hline $10 \mathrm{H}-6,133-137$ & 92.05 & 3.49 & -0.72 \\
\hline $10 \mathrm{H}-7,3-7$ & 92.25 & 3.86 & -0.99 \\
\hline $10 \mathrm{H}-7,3-7$ & 92.25 & 3.83 & -0.83 \\
\hline $10 \mathrm{H}-7,24-28$ & 92.46 & 3.79 & -0.94 \\
\hline $11 \mathrm{H}-1,5-9$ & 92.77 & 3.81 & -0.44 \\
\hline $11 \mathrm{H}-1,5-9$ & 92.77 & 3.42 & -0.64 \\
\hline $11 \mathrm{H}-1,29-33$ & 93.01 & 3.47 & -0.15 \\
\hline $11 \mathrm{H}-1,63-67$ & 93.35 & 3.42 & -0.42 \\
\hline $11 \mathrm{H}-1,63-67$ & 93.35 & 3.19 & -0.72 \\
\hline $11 H-1,98-100$ & 93.69 & 3.27 & -0.47 \\
\hline $11 \mathrm{H}-1,129-131$ & 94.00 & 3.22 & -0.54 \\
\hline $11 \mathrm{H}-1,129-131$ & 94.00 & 3.16 & -0.53 \\
\hline $11 \mathrm{H}-2,3-7$ & 94.25 & 3.35 & -0.37 \\
\hline $11 \mathrm{H}-2,3-7$ & 94.25 & 3.24 & -0.48 \\
\hline $11 \mathrm{H}-2,35-37$ & 94.57 & 2.98 & -0.56 \\
\hline $11 \mathrm{H}-2,62-66$ & 94.84 & 2.97 & -0.45 \\
\hline
\end{tabular}


Table 2 (continued).

\begin{tabular}{|c|c|c|c|}
\hline $\begin{array}{l}\text { Core, section, } \\
\text { interval }(\mathrm{cm})\end{array}$ & $\begin{array}{l}\text { Depth } \\
\text { (mbsf) }\end{array}$ & $\begin{array}{c}\delta^{18} \mathrm{O} \\
(\% \text { PDB })\end{array}$ & $\begin{array}{c}\delta^{13} \mathrm{O} \\
(\% \text { PDB })\end{array}$ \\
\hline $11 \mathrm{H}-2,88-92$ & 95.10 & 3.03 & -0.57 \\
\hline $11 \mathrm{H}-2,124-128$ & 95.46 & 3.27 & -0.74 \\
\hline $11 \mathrm{H}-3,3-7$ & 95.75 & 3.34 & -0.73 \\
\hline $11 \mathrm{H}-3,34-38$ & 96.06 & 3.26 & -0.64 \\
\hline $11 \mathrm{H}-3,63-67$ & 96.35 & 3.38 & -0.78 \\
\hline $11 \mathrm{H}-3,94-98$ & 96.66 & 3.44 & -0.70 \\
\hline $11 \mathrm{H}-3,124-128$ & 96.96 & 3.39 & -0.77 \\
\hline $11 \mathrm{H}-4,3-7$ & 97.25 & 3.36 & -0.79 \\
\hline $11 \mathrm{H}-4,33-37$ & 97.55 & 3.37 & -0.72 \\
\hline $11 \mathrm{H}-4,64-68$ & 97.86 & 3.49 & -0.44 \\
\hline $11 \mathrm{H}-4,98-102$ & 98.20 & 3.42 & -0.06 \\
\hline $11 \mathrm{H}-4,123-125$ & 98.44 & 3.51 & -0.41 \\
\hline $11 \mathrm{H}-5,3-7$ & 98.75 & 3.75 & -0.43 \\
\hline $11 \mathrm{H}-5,33-37$ & 99.05 & 3.51 & -0.33 \\
\hline 11H-5, 97-101 & 99.69 & 3.72 & -0.04 \\
\hline $11 \mathrm{H}-5,124-128$ & 99.96 & 3.57 & -0.26 \\
\hline $11 \mathrm{H}-5,142-146$ & 100.14 & 3.57 & -0.15 \\
\hline $11 \mathrm{H}-6,3-7$ & 100.25 & 3.51 & -0.07 \\
\hline $11 \mathrm{H}-6,33-37$ & 100.55 & 3.13 & 0.09 \\
\hline $11 \mathrm{H}-6,85-89$ & 101.07 & 3.15 & 0.10 \\
\hline $11 \mathrm{H}-6,127-129$ & 101.48 & 3.30 & -0.10 \\
\hline $11 \mathrm{H}-7,3-7$ & 101.75 & 3.46 & -0.55 \\
\hline $11 \mathrm{H}-7,36-40$ & 102.08 & 3.29 & -0.20 \\
\hline $12 \mathrm{H}-1,3-7$ & 102.25 & 3.07 & -0.01 \\
\hline $12 \mathrm{H}-1,3-7$ & 102.25 & 3.28 & -0.16 \\
\hline $12 \mathrm{H}-1,27-31$ & 102.49 & 2.85 & -0.20 \\
\hline $12 \mathrm{H}-1,63-67$ & 102.85 & 2.88 & -0.21 \\
\hline $12 \mathrm{H}-1,94-98$ & 103.16 & 3.13 & -0.19 \\
\hline $12 \mathrm{H}-1,124-128$ & 103.46 & 3.13 & -0.27 \\
\hline $12 \mathrm{H}-2,3-7$ & 103.75 & 3.17 & 0.07 \\
\hline $12 \mathrm{H}-2,33-37$ & 104.05 & 3.17 & -0.36 \\
\hline $12 \mathrm{H}-2,63-67$ & 104.35 & 3.57 & -0.75 \\
\hline $12 \mathrm{H}-2,124-128$ & 104.96 & 3.18 & -0.48 \\
\hline $12 \mathrm{H}-2,124-128$ & 104.96 & 3.45 & -0.29 \\
\hline $12 \mathrm{H}-3,3-7$ & 105.25 & 2.99 & -0.19 \\
\hline $12 \mathrm{H}-3,34-38$ & 105.56 & 2.97 & -0.04 \\
\hline $12 \mathrm{H}-3,85-89$ & 106.07 & 2.85 & 0.10 \\
\hline $12 \mathrm{H}-3,125-127$ & 106.46 & 2.78 & 0.18 \\
\hline $12 \mathrm{H}-4,3-7$ & 106.75 & 2.88 & 0.10 \\
\hline $12 \mathrm{H}-4,3-7$ & 106.75 & 3.21 & 0.03 \\
\hline $12 \mathrm{H}-4,29-33$ & 107.01 & 3.36 & -0.74 \\
\hline $12 \mathrm{H}-4,57-61$ & 107.29 & 3.33 & -0.37 \\
\hline $12 \mathrm{H}-4,93-97$ & 107.65 & 3.21 & -0.13 \\
\hline $12 \mathrm{H}-4,128-132$ & 108.00 & 3.01 & 0.15 \\
\hline $12 \mathrm{H}-5,34-38$ & 108.56 & 3.30 & -0.13 \\
\hline $12 \mathrm{H}-5,94-98$ & 109.16 & 3.24 & 0.35 \\
\hline $12 \mathrm{H}-6,3-7$ & 109.75 & 3.39 & -0.13 \\
\hline $12 \mathrm{H}-6,43-47$ & 110.15 & 3.35 & -0.04 \\
\hline $12 \mathrm{H}-6,43-47$ & 110.15 & 3.43 & 0.06 \\
\hline $12 \mathrm{H}-6,93-97$ & 110.65 & 3.18 & -0.05 \\
\hline $12 \mathrm{H}-6,124-128$ & 110.96 & 3.25 & -0.10 \\
\hline $12 \mathrm{H}-6,124-128$ & 110.96 & 3.66 & 0.08 \\
\hline $13 \mathrm{H}-1,33-37$ & 112.05 & 3.48 & -0.52 \\
\hline $13 \mathrm{H}-1,127-129$ & 112.98 & 3.84 & -0.79 \\
\hline $13 \mathrm{H}-2,34-38$ & 113.56 & 3.31 & -0.45 \\
\hline $13 \mathrm{H}-2,92-94$ & 114.13 & 3.71 & -0.37 \\
\hline $13 \mathrm{H}-2,127-131$ & 114.49 & 3.59 & -0.54 \\
\hline $13 \mathrm{H}-3,3-7$ & 114.75 & 3.43 & -0.30 \\
\hline $13 \mathrm{H}-3,33-37$ & 115.05 & 3.35 & -0.55 \\
\hline $13 \mathrm{H}-3,63-67$ & 115.35 & 3.39 & -0.35 \\
\hline
\end{tabular}

Table 2 (continued).

\begin{tabular}{|c|c|c|c|}
\hline $\begin{array}{l}\text { Core, section, } \\
\text { interval }(\mathrm{cm})\end{array}$ & $\begin{array}{l}\text { Depth } \\
\text { (mbsf) }\end{array}$ & $\begin{array}{c}\delta^{18} \mathrm{O} \\
(\% o \text { PDB })\end{array}$ & $\begin{array}{c}\delta^{13} \mathrm{O} \\
(\% \text { PDB })\end{array}$ \\
\hline $13 \mathrm{H}-3,126-130$ & 115.98 & 2.97 & -0.06 \\
\hline $13 \mathrm{H}-4,3-7$ & 116.25 & 3.03 & -0.10 \\
\hline $13 \mathrm{H}-4,63-67$ & 116.85 & 3.46 & -0.35 \\
\hline $13 \mathrm{H}-4,93-97$ & 117.15 & 3.02 & 0.75 \\
\hline $13 \mathrm{H}-6,3-7$ & 119.25 & 3.31 & -0.47 \\
\hline $13 \mathrm{H}-6,33-37$ & 119.55 & 3.18 & -0.13 \\
\hline $13 \mathrm{H}-6,63-67$ & 119.85 & 3.08 & -0.13 \\
\hline $14 \mathrm{H}-1,28-32$ & 121.50 & 3.30 & -0.37 \\
\hline $14 \mathrm{H}-1,28-32$ & 121.50 & 3.32 & -0.12 \\
\hline $14 \mathrm{H}-1,63-67$ & 121.85 & 3.43 & -0.19 \\
\hline $14 \mathrm{H}-1,63-67$ & 121.85 & 3.69 & -0.28 \\
\hline $14 \mathrm{H}-2,3-7$ & 122.75 & 3.50 & -0.07 \\
\hline $14 \mathrm{H}-2,35-39$ & 123.07 & 3.50 & -0.16 \\
\hline $14 \mathrm{H}-2,35-39$ & 123.07 & 3.51 & -0.39 \\
\hline $14 \mathrm{H}-2,63-67$ & 123.35 & 3.27 & -0.34 \\
\hline $14 \mathrm{H}-2,63-67$ & 123.35 & 3.35 & -0.29 \\
\hline $14 \mathrm{H}-2,94-98$ & 123.66 & 3.51 & -0.19 \\
\hline $14 \mathrm{H}-2,94-98$ & 123.66 & 3.38 & -0.20 \\
\hline $14 \mathrm{H}-3,50-52$ & 124.71 & 3.49 & -0.05 \\
\hline $14 \mathrm{H}-3,62-66$ & 124.84 & 3.17 & 0.06 \\
\hline $14 \mathrm{H}-3,123-127$ & 125.45 & 3.66 & -0.62 \\
\hline $14 \mathrm{H}-4,3-7$ & 125.75 & 2.81 & 0.32 \\
\hline $14 \mathrm{H}-4,65-69$ & 126.37 & 3.35 & -0.19 \\
\hline $14 \mathrm{H}-4,123-127$ & 126.95 & 3.04 & 0.07 \\
\hline $14 \mathrm{H}-5,28-32$ & 127.50 & 3.49 & -0.03 \\
\hline $14 \mathrm{H}-5,83-87$ & 128.05 & 3.28 & -0.03 \\
\hline $14 \mathrm{H}-5,123-127$ & 128.45 & 3.09 & 0.13 \\
\hline $14 \mathrm{H}-6,3-7$ & 128.75 & 3.26 & -0.23 \\
\hline $14 \mathrm{H}-6,33-37$ & 129.05 & 3.32 & -0.61 \\
\hline $14 \mathrm{H}-6,63-67$ & 129.35 & 3.70 & -0.54 \\
\hline $15 \mathrm{H}-1,64-68$ & 131.36 & 3.04 & 0.23 \\
\hline $15 \mathrm{H}-1,92-96$ & 131.64 & 3.14 & 0.21 \\
\hline $15 \mathrm{H}-1,126-130$ & 131.98 & 3.05 & 0.19 \\
\hline $15 \mathrm{H}-2,3-7$ & 132.25 & 3.15 & 0.53 \\
\hline $15 \mathrm{H}-2,34-38$ & 132.56 & 2.90 & 0.27 \\
\hline $15 \mathrm{H}-2,92-96$ & 133.14 & 3.19 & 0.08 \\
\hline $15 \mathrm{H}-3,3-7$ & 133.75 & 2.93 & 0.60 \\
\hline $15 \mathrm{H}-4,3-7$ & 135.25 & 2.96 & 0.04 \\
\hline $15 \mathrm{H}-4,92-96$ & 136.14 & 2.70 & 0.36 \\
\hline $15 \mathrm{H}-4,124-128$ & 136.46 & 3.12 & 0.27 \\
\hline $15 \mathrm{H}-5,35-39$ & 137.07 & 3.17 & -0.67 \\
\hline $15 \mathrm{H}-5,35-39$ & 137.07 & 3.12 & -0.47 \\
\hline $15 \mathrm{H}-5,63-67$ & 137.35 & 3.31 & -0.36 \\
\hline $15 \mathrm{H}-5,63-67$ & 137.35 & 3.05 & -0.24 \\
\hline $15 \mathrm{H}-5,92-96$ & 137.64 & 2.75 & 0.25 \\
\hline $15 \mathrm{H}-6,63-67$ & 138.85 & 2.78 & 0.36 \\
\hline $15 \mathrm{H}-6,93-97$ & 139.15 & 2.87 & 0.37 \\
\hline $15 \mathrm{H}-7,2-6$ & 139.74 & 2.96 & 0.47 \\
\hline $15 \mathrm{H}-7,32-36$ & 140.05 & 3.01 & 0.05 \\
\hline $16 \mathrm{H}-1,83-87$ & 141.05 & 3.32 & -0.05 \\
\hline $16 \mathrm{H}-1,90-94$ & 141.15 & 3.23 & -0.28 \\
\hline $16 \mathrm{H}-1,123-127$ & 141.50 & 3.22 & 0.11 \\
\hline $16 \mathrm{H}-2,19-23$ & 141.91 & 3.48 & -0.32 \\
\hline $16 \mathrm{H}-2,38-42$ & 142.10 & 3.60 & -0.37 \\
\hline $16 \mathrm{H}-2,138-142$ & 143.10 & 3.29 & -0.05 \\
\hline $16 \mathrm{H}-3,3-7$ & 143.25 & 3.29 & -0.02 \\
\hline $16 \mathrm{H}-3,33-37$ & 143.55 & 3.07 & 0.52 \\
\hline $16 \mathrm{H}-3,43-47$ & 143.65 & 3.45 & -0.22 \\
\hline $16 \mathrm{H}-3,64-67$ & 143.85 & 3.15 & -0.27 \\
\hline $16 \mathrm{H}-3,64-67$ & 143.85 & 3.28 & -0.41 \\
\hline
\end{tabular}


Table 2 (continued).

\begin{tabular}{|c|c|c|c|}
\hline $\begin{array}{l}\text { Core, section, } \\
\text { interval (cm) }\end{array}$ & $\begin{array}{l}\text { Depth } \\
\text { (mbsf) }\end{array}$ & $\begin{array}{c}\delta^{18} \mathrm{O} \\
(\% \circ \mathrm{PDB})\end{array}$ & $\begin{array}{c}\delta^{13} \mathrm{O} \\
(\% \text { PDB })\end{array}$ \\
\hline $16 \mathrm{H}-3,95-99$ & 144.17 & 2.98 & 0.41 \\
\hline $16 \mathrm{H}-4,94-98$ & 145.66 & 2.81 & 0.53 \\
\hline $16 \mathrm{H}-4,128-132$ & 146.00 & 3.30 & 0.36 \\
\hline $17 X-1,36-40$ & 150.08 & 3.14 & -0.10 \\
\hline $17 X-1,63-67$ & 150.35 & 3.15 & -0.35 \\
\hline $17 X-1,93-97$ & 150.65 & 3.12 & 0.24 \\
\hline $17 \mathrm{X}-2,33-37$ & 151.55 & 2.97 & 0.39 \\
\hline $17 X-2,80-82$ & 152.01 & 3.05 & 0.18 \\
\hline $17 \mathrm{X}-2,95-99$ & 152.17 & 3.32 & 0.26 \\
\hline $17 X-2,119-123$ & 152.41 & 3.38 & -0.28 \\
\hline $17 X-2,139-143$ & 152.61 & 3.27 & 0.06 \\
\hline $17 X-3,3-7$ & 152.75 & 2.96 & 0.48 \\
\hline $17 X-3,64-68$ & 153.36 & 2.97 & 0.45 \\
\hline $17 X-3,97-101$ & 153.69 & 3.03 & -0.04 \\
\hline $17 X-3,126-130$ & 153.98 & 3.02 & 0.09 \\
\hline $17 X-4,3-7$ & 154.25 & 2.94 & 0.08 \\
\hline $17 X-4,34-38$ & 154.56 & 3.05 & 0.32 \\
\hline $17 X-4,63-67$ & 154.85 & 3.47 & -0.22 \\
\hline $17 X-4,63-67$ & 154.85 & 3.28 & -0.33 \\
\hline $17 X-4,95-99$ & 155.17 & 3.45 & -0.11 \\
\hline $17 X-4,126-130$ & 155.48 & 3.25 & 0.30 \\
\hline $17 X-5,33-37$ & 156.05 & 3.44 & -0.43 \\
\hline $17 X-5,63-67$ & 156.35 & 2.93 & 0.00 \\
\hline $17 X-5,127-131$ & 156.99 & 3.06 & 0.17 \\
\hline $17 X-6,3-7$ & 157.25 & 3.01 & 0.32 \\
\hline $17 X-6,27-31$ & 157.49 & 3.24 & -0.15 \\
\hline $17 X-6,62-66$ & 157.84 & 3.21 & 0.03 \\
\hline $18 X-1,15-19$ & 159.37 & 3.59 & -0.30 \\
\hline $18 X-1,96-100$ & 160.18 & 3.44 & -0.61 \\
\hline $18 X-1,116-120$ & 160.38 & 3.50 & 0.31 \\
\hline $18 X-2,61-65$ & 161.33 & 3.55 & 0.22 \\
\hline $18 \mathrm{X}-2,125-129$ & 161.97 & 3.32 & 0.90 \\
\hline $18 X-3,1-5$ & 162.23 & 3.18 & 0.42 \\
\hline $18 \mathrm{X}-3,28-32$ & 162.50 & 3.38 & -0.04 \\
\hline $18 X-3,61-65$ & 162.83 & 3.24 & -0.12 \\
\hline $18 X-3,63-67$ & 162.85 & 3.57 & -0.27 \\
\hline $18 X-3,86-90$ & 163.08 & 3.06 & 0.24 \\
\hline $18 X-4,3-7$ & 163.75 & 2.79 & 0.62 \\
\hline $18 \mathrm{X}-4,32-36$ & 164.04 & 3.40 & -0.22 \\
\hline $18 X-4,93-97$ & 164.65 & 3.30 & 0.68 \\
\hline $18 X-5,22-26$ & 165.44 & 3.21 & 0.71 \\
\hline $18 X-5,35-39$ & 165.57 & 3.13 & 0.48 \\
\hline $18 X-5,61-63$ & 165.85 & 3.31 & -0.12 \\
\hline $18 X-5,93-97$ & 166.15 & 3.25 & -0.36 \\
\hline $18 X-5,127-131$ & 166.49 & 2.90 & 0.34 \\
\hline $18 X-6,3-7$ & 166.75 & 3.21 & 0.57 \\
\hline $18 X-6,28-32$ & 167.00 & 3.60 & -0.53 \\
\hline $18 X-6,68-70$ & 167.39 & 3.50 & -0.48 \\
\hline $18 \mathrm{X}-\mathrm{CC}, 6-10$ & 168.20 & 2.96 & -0.19 \\
\hline $18 \mathrm{X}-\mathrm{CC}, 6-10$ & 168.20 & 2.96 & 0.19 \\
\hline $19 \mathrm{X}-1,6-10$ & 168.78 & 3.39 & 0.13 \\
\hline $19 \mathrm{X}-1,20-22$ & 168.91 & 3.12 & 0.25 \\
\hline $19 \mathrm{X}-1,30-34$ & 169.02 & 3.71 & 0.01 \\
\hline $19 X-1,33-37$ & 169.05 & 3.39 & 0.02 \\
\hline $19 X-1,50-52$ & 169.21 & 2.90 & 0.72 \\
\hline $19 X-1,75-77$ & 169.46 & 3.26 & 0.44 \\
\hline $19 \mathrm{X}-1,87-91$ & 169.59 & 2.97 & 0.32 \\
\hline $19 \mathrm{X}-1,124-128$ & 169.96 & 2.74 & 1.44 \\
\hline $19 X-1,143-147$ & 170.15 & 3.22 & 0.73 \\
\hline $19 X-2,20-22$ & 170.41 & 3.03 & 0.15 \\
\hline
\end{tabular}

Table 2 (continued).

\begin{tabular}{|c|c|c|c|}
\hline $\begin{array}{l}\text { Core, section, } \\
\text { interval }(\mathrm{cm})\end{array}$ & $\begin{array}{l}\text { Depth } \\
\text { (mbsf) }\end{array}$ & $\begin{array}{c}\delta^{18} \mathrm{O} \\
(\% \text { PDB })\end{array}$ & $\begin{array}{c}\delta^{13} \mathrm{O} \\
(\% \text { PDB })\end{array}$ \\
\hline $19 \mathrm{X}-2,20-22$ & 170.41 & 3.02 & 0.71 \\
\hline $19 \mathrm{X}-2,30-34$ & 170.52 & 3.31 & 0.50 \\
\hline $19 X-2,30-34$ & 170.52 & 3.21 & 0.55 \\
\hline $19 \mathrm{X}-2,33-37$ & 170.55 & 2.82 & 0.94 \\
\hline $19 X-2,33-37$ & 170.55 & 2.77 & 0.77 \\
\hline $19 X-2,46-50$ & 170.68 & 3.11 & 0.88 \\
\hline $19 X-2,46-50$ & 170.68 & 3.06 & 0.71 \\
\hline $19 X-2,50-52$ & 170.71 & 3.12 & 0.64 \\
\hline $19 X-2,60-62$ & 170.81 & 2.98 & 0.67 \\
\hline $19 X-2,60-62$ & 170.81 & 2.98 & 0.46 \\
\hline $19 \mathrm{X}-2,76-80$ & 170.98 & 3.14 & 0.52 \\
\hline $19 X-2,93-97$ & 171.15 & 3.04 & 0.79 \\
\hline $19 X-2,110-112$ & 171.31 & 3.09 & 0.77 \\
\hline $19 \mathrm{X}-2,110-112$ & 171.31 & 2.68 & 0.70 \\
\hline $19 X-2,125-129$ & 171.47 & 2.57 & 0.77 \\
\hline $19 X-2,140-142$ & 171.61 & 2.91 & 0.66 \\
\hline $19 X-2,140-142$ & 171.61 & 2.99 & 0.62 \\
\hline $19 X-3,7-9$ & 171.78 & 3.24 & 1.12 \\
\hline $19 X-3,27-29$ & 171.98 & 3.26 & 0.77 \\
\hline $19 \mathrm{X}-3,27-29$ & 171.98 & 3.21 & 0.60 \\
\hline $19 X-3,50-52$ & 172.21 & 2.59 & 0.71 \\
\hline $19 X-3,50-52$ & 172.21 & 2.73 & 0.61 \\
\hline $19 \mathrm{X}-3,62-66$ & 172.31 & 3.08 & 0.61 \\
\hline $19 X-3,62-66$ & 172.34 & 3.10 & 0.95 \\
\hline $19 X-3,94-98$ & 172.66 & 3.12 & 0.69 \\
\hline $19 \mathrm{X}-3,94-98$ & 172.66 & 3.07 & 0.52 \\
\hline $19 \mathrm{X}-3,110-112$ & 172.81 & 3.33 & 0.75 \\
\hline $19 \mathrm{X}-3,112-116$ & 172.84 & 3.21 & 0.90 \\
\hline $19 X-3,112-116$ & 172.84 & 3.16 & 0.73 \\
\hline $19 \mathrm{X}-3,128-132$ & 173.00 & 3.17 & 0.90 \\
\hline $19 \mathrm{X}-3,128-132$ & 173.00 & 3.12 & 0.73 \\
\hline $19 X-3,140-142$ & 173.11 & 3.01 & 0.80 \\
\hline $19 X-4,1-5$ & 173.23 & 3.05 & 0.76 \\
\hline $19 X-4,1-5$ & 173.23 & 3.00 & 0.59 \\
\hline $19 X-4,20-22$ & 173.41 & 2.72 & 0.37 \\
\hline $19 \mathrm{X}-4,20-22$ & 173.41 & 2.80 & 0.57 \\
\hline $19 X-4,30-34$ & 173.52 & 3.14 & 0.07 \\
\hline $19 X-4,30-34$ & 173.52 & 3.21 & 0.11 \\
\hline $19 X-4,34-38$ & 173.56 & 3.04 & 0.39 \\
\hline $19 X-4,34-38$ & 173.56 & 3.19 & 0.30 \\
\hline $19 X-4,50-52$ & 173.71 & 2.95 & 0.99 \\
\hline $19 X-4,50-52$ & 173.71 & 2.42 & 0.74 \\
\hline $19 X-4,60-62$ & 173.81 & 2.34 & 0.73 \\
\hline $19 X-4,66-70$ & 173.88 & 3.20 & 0.78 \\
\hline $19 X-4,86-90$ & 174.07 & 2.87 & 0.89 \\
\hline $19 X-4,124-128$ & 174.46 & 3.08 & 0.62 \\
\hline $19 X-4,140-142$ & 174.61 & 2.75 & 0.57 \\
\hline $19 X-5,1-5$ & 174.73 & 2.95 & 0.51 \\
\hline $19 X-5,20-22$ & 174.91 & 2.85 & 0.51 \\
\hline $19 X-5,30-34$ & 175.02 & 3.39 & 0.57 \\
\hline $19 X-5,30-34$ & 175.02 & 3.15 & 0.55 \\
\hline $19 X-5,30-34$ & 175.02 & 2.78 & 0.38 \\
\hline $19 X-5,42-44$ & 175.13 & 3.19 & 0.56 \\
\hline $19 X-5,50-52$ & 175.21 & 3.35 & 0.33 \\
\hline $19 X-5,60-62$ & 175.31 & 3.51 & 0.29 \\
\hline $19 X-5,76-80$ & 175.48 & 3.29 & 0.15 \\
\hline $19 X-5,98-102$ & 175.70 & 3.33 & 0.09 \\
\hline $19 X-5,110-112$ & 175.81 & 2.77 & 0.18 \\
\hline $19 X-5,123-127$ & 175.95 & 2.87 & 0.65 \\
\hline $19 X-5,123-127$ & 175.95 & 3.05 & 0.61 \\
\hline
\end{tabular}


Table 2 (continued).

\begin{tabular}{|c|c|c|c|}
\hline $\begin{array}{l}\text { Core, section, } \\
\text { interval }(\mathrm{cm})\end{array}$ & $\begin{array}{l}\text { Depth } \\
\text { (mbsf) }\end{array}$ & $\begin{array}{c}\delta^{18} \mathrm{O} \\
(\% \circ \mathrm{PDB})\end{array}$ & $\begin{array}{c}\delta^{13} \mathrm{O} \\
(\% \text { PDB })\end{array}$ \\
\hline $19 \mathrm{X}-5,140-142$ & 176.11 & 2.88 & 0.12 \\
\hline $19 X-6,1-5$ & 176.23 & 3.18 & 0.36 \\
\hline $19 X-6,1-5$ & 176.23 & 2.92 & 0.31 \\
\hline $19 \mathrm{X}-6,20-22$ & 176.41 & 3.11 & 0.30 \\
\hline $19 \mathrm{X}-6,34-38$ & 176.56 & 3.03 & 0.69 \\
\hline $19 \mathrm{X}-6,34-38$ & 176.56 & 2.82 & 0.60 \\
\hline $19 \mathrm{X}-6,50-52$ & 176.71 & 2.60 & 0.46 \\
\hline $19 \mathrm{X}-6,60-62$ & 176.81 & 2.55 & 0.35 \\
\hline $19 \mathrm{X}-6,74-78$ & 176.96 & 3.01 & 0.79 \\
\hline $19 X-6,74-78$ & 176.96 & 3.07 & 0.72 \\
\hline $19 \mathrm{X}-6,93-97$ & 177.15 & 3.08 & 0.87 \\
\hline $19 X-6,110-112$ & 177.31 & 2.78 & 0.74 \\
\hline $19 X-6,110-112$ & 177.31 & 2.66 & 0.90 \\
\hline $19 X-6,123-127$ & 177.45 & 3.11 & 0.79 \\
\hline $19 X-6,123-127$ & 177.45 & 2.78 & 0.69 \\
\hline $19 \mathrm{X}-6,140-142$ & 177.61 & 3.21 & 0.59 \\
\hline $19 X-6,143-147$ & 177.65 & 3.05 & 0.64 \\
\hline $19 X-7,3-7$ & 177.75 & 3.08 & 0.63 \\
\hline $19 X-7,18-22$ & 177.90 & 3.29 & 0.25 \\
\hline $20 \mathrm{X}-1,27-31$ & 178.49 & 2.81 & 0.78 \\
\hline $20 \mathrm{X}-1,62-66$ & 178.84 & 2.75 & 0.85 \\
\hline $20 \mathrm{X}-1,94-98$ & 179.16 & 2.91 & 0.85 \\
\hline $20 \mathrm{X}-1,110-112$ & 179.31 & 2.73 & 0.66 \\
\hline $20 \mathrm{X}-1,123-127$ & 179.45 & 2.85 & 0.76 \\
\hline $20 X-1,143-147$ & 179.65 & 2.74 & 0.76 \\
\hline $20 \times-2,3-7$ & 179.75 & 2.89 & 0.82 \\
\hline $20 X-2,46-48$ & 180.17 & 2.84 & 0.58 \\
\hline $20 X-2,63-67$ & 180.35 & 2.89 & 0.61 \\
\hline $20 \mathrm{X}-2,68-72$ & 180.40 & 2.94 & 0.65 \\
\hline $20 \mathrm{X}-2,80-82$ & 180.51 & 2.83 & 0.62 \\
\hline $20 \mathrm{X}-2,98-102$ & 180.70 & 3.02 & 0.75 \\
\hline $20 \mathrm{X}-2,123-127$ & 180.95 & 3.23 & 0.37 \\
\hline $20 \mathrm{X}-2,140-142$ & 181.11 & 3.09 & 0.12 \\
\hline $20 x-3,3-7$ & 181.25 & 2.99 & 0.45 \\
\hline $20 \times-3,33-37$ & 181.55 & 2.79 & 0.39 \\
\hline $20 \mathrm{X}-3,94-98$ & 182.16 & 2.79 & 0.66 \\
\hline $20 \mathrm{X}-3,121-125$ & 182.43 & 2.77 & 0.65 \\
\hline $20 \mathrm{X}-4,28-32$ & 183.00 & 2.79 & 0.69 \\
\hline $20 X-4,62-66$ & 183.34 & 2.84 & 0.61 \\
\hline $20 X-4,80-82$ & 183.51 & 2.57 & 0.30 \\
\hline $20 \mathrm{X}-4,95-99$ & 183.67 & 2.70 & 0.49 \\
\hline $20 X-4,113-117$ & 183.85 & 2.81 & 0.41 \\
\hline $20 X-4,140-142$ & 184.11 & 2.92 & 0.43 \\
\hline $20 X-4,142-146$ & 184.14 & 2.61 & 0.52 \\
\hline $20 X-5,3-7$ & 184.25 & 2.68 & 0.67 \\
\hline $20 X-5,20-22$ & 184.41 & 2.54 & 0.86 \\
\hline $20 X-5,36-40$ & 184.58 & 2.72 & 0.44 \\
\hline $20 X-5,62-66$ & 184.84 & 2.89 & 0.73 \\
\hline $20 X-5,68-72$ & 184.90 & 2.84 & 0.62 \\
\hline $20 \mathrm{X}-5,95-99$ & 185.17 & 2.71 & 0.78 \\
\hline $20 X-5,110-112$ & 185.31 & 2.48 & 0.69 \\
\hline $20 \times-6,3-7$ & 185.75 & 2.74 & 0.65 \\
\hline $20 X-6,20-22$ & 185.91 & 2.67 & 0.38 \\
\hline $20 \mathrm{X}-6,22-26$ & 185.94 & 2.67 & 0.49 \\
\hline $20 X-6,42-44$ & 186.14 & 2.73 & 0.69 \\
\hline $20 \mathrm{X}-6,62-66$ & 186.34 & 2.83 & 0.70 \\
\hline $20 \times-6,110-112$ & 186.81 & 2.61 & 0.79 \\
\hline $20 \times-7,3-7$ & 187.25 & 2.69 & 0.48 \\
\hline $20 X-7,20-22$ & 187.41 & 3.08 & 0.38 \\
\hline $20 X-7,28-32$ & 188.00 & 2.73 & 0.25 \\
\hline
\end{tabular}

Table 2 (continued).

\begin{tabular}{|c|c|c|c|}
\hline $\begin{array}{l}\text { Core, section, } \\
\text { interval }(\mathrm{cm})\end{array}$ & $\begin{array}{l}\text { Depth } \\
\text { (mbsf) }\end{array}$ & $\begin{array}{c}\delta^{18} \mathrm{O} \\
(\% \text { PDB })\end{array}$ & $\begin{array}{c}\delta^{13} \mathrm{O} \\
(\% \mathrm{PDB})\end{array}$ \\
\hline $20 X-7,44-46$ & 188.16 & 2.39 & 0.49 \\
\hline $21 X-1,80-82$ & 188.51 & 2.36 & -0.20 \\
\hline $21 X-1,110-112$ & 188.81 & 2.81 & -0.12 \\
\hline $21 X-1,140-142$ & 189.11 & 2.48 & 0.38 \\
\hline $21 X-1,140-142$ & 189.66 & 2.75 & 0.40 \\
\hline $21 X-2,80-82$ & 190.01 & 2.21 & 0.46 \\
\hline $21 X-2,80-82$ & 190.01 & 2.54 & 0.45 \\
\hline $21 X-2,80-82$ & 190.01 & 2.54 & 0.45 \\
\hline $21 X-2,110-112$ & 190.31 & 2.70 & -0.06 \\
\hline $21 X-2,140-142$ & 190.61 & 2.57 & 0.42 \\
\hline $21 X-3,28-32$ & 191.00 & 2.16 & 0.06 \\
\hline $21 X-3,45-47$ & 191.16 & 2.38 & 0.30 \\
\hline $21 X-3,80-82$ & 191.51 & 2.59 & 0.06 \\
\hline $21 X-3,110-112$ & 191.81 & 2.48 & 0.49 \\
\hline $21 X-4,45-47$ & 192.66 & 2.69 & 0.38 \\
\hline $21 X-4,68-72$ & 192.90 & 2.18 & -0.08 \\
\hline $21 X-4,80-82$ & 193.01 & 2.64 & 0.30 \\
\hline $21 X-4,80-82$ & 193.01 & 2.27 & -0.40 \\
\hline $22 \mathrm{X}-1,20-22$ & 197.41 & 2.19 & 0.56 \\
\hline $22 \mathrm{X}-1,81-83$ & 198.02 & 2.50 & 0.27 \\
\hline $22 X-1,110-112$ & 198.31 & 2.15 & 0.48 \\
\hline $22 X-1,110-112$ & 198.31 & 2.17 & 0.39 \\
\hline $22 \mathrm{X}-1,129-131$ & 198.50 & 2.03 & -0.10 \\
\hline $22 \mathrm{X}-1,139-141$ & 198.60 & 2.53 & 0.51 \\
\hline $22 \mathrm{X}-2,90-94$ & 199.62 & 2.20 & 0.09 \\
\hline $22 X-2,110-112$ & 199.81 & 2.46 & 0.47 \\
\hline $22 X-3,90-94$ & 201.12 & 2.81 & 0.56 \\
\hline $22 X-3,140-142$ & 201.60 & 2.63 & 0.72 \\
\hline $22 X-4,81-83$ & 202.52 & 2.72 & 0.51 \\
\hline $22 X-4,90-94$ & 202.62 & 2.59 & 0.46 \\
\hline $22 X-5,20-22$ & 203.41 & 1.86 & 0.01 \\
\hline $22 X-5,139-141$ & 204.60 & 2.52 & 0.52 \\
\hline $23 \mathrm{X}-1,20-22$ & 206.91 & 2.71 & 0.40 \\
\hline $23 \mathrm{X}-1,58-62$ & 207.30 & 2.58 & 0.42 \\
\hline $23 \mathrm{X}-1,80-82$ & 207.51 & 2.37 & 0.45 \\
\hline $23 \mathrm{X}-1,80-82$ & 207.51 & 2.35 & 0.49 \\
\hline $23 \mathrm{X}-1,110-112$ & 207.81 & 2.59 & 0.17 \\
\hline $23 \mathrm{X}-1,140-142$ & 208.11 & 2.79 & 0.23 \\
\hline $23 \mathrm{X}-2,20-22$ & 208.41 & 2.22 & 0.24 \\
\hline $23 \mathrm{X}-2,20-22$ & 208.41 & 2.58 & 0.44 \\
\hline $23 \mathrm{X}-2,58-62$ & 208.80 & 2.58 & 0.40 \\
\hline $23 \mathrm{X}-2,80-82$ & 209.01 & 2.54 & 0.03 \\
\hline $23 X-2,110-112$ & 209.31 & 2.21 & 0.18 \\
\hline $23 \mathrm{X}-2,140-142$ & 209.61 & 2.57 & 0.13 \\
\hline $23 \mathrm{X}-3,20-22$ & 209.91 & 2.51 & 0.44 \\
\hline $23 \mathrm{X}-3,20-22$ & 209.91 & 2.51 & 0.44 \\
\hline $23 \mathrm{X}-3,58-62$ & 210.30 & 2.39 & 0.51 \\
\hline $23 \mathrm{X}-3,80-82$ & 210.51 & 2.39 & 0.01 \\
\hline $23 \mathrm{X}-3,110-112$ & 210.81 & 2.50 & 0.56 \\
\hline $23 X-3,110-112$ & 210.81 & 2.09 & 0.22 \\
\hline $23 \mathrm{X}-3,140-142$ & 211.11 & 2.59 & 0.36 \\
\hline $23 \mathrm{X}-4,20-22$ & 211.41 & 2.40 & 0.29 \\
\hline $23 \mathrm{X}-4,20-22$ & 211.41 & 2.23 & -0.04 \\
\hline $23 X-4,58-62$ & 211.80 & 2.67 & 0.50 \\
\hline $23 X-4,80-82$ & 212.01 & 2.31 & 0.10 \\
\hline $23 X-4,110-112$ & 212.31 & 2.72 & 0.37 \\
\hline $23 X-4,140-142$ & 212.61 & 2.47 & 0.57 \\
\hline $23 \mathrm{X}-4,140-142$ & 212.61 & 2.42 & -0.02 \\
\hline $23 \mathrm{X}-5,20-22$ & 212.91 & 2.60 & 0.21 \\
\hline $23 \mathrm{X}-5,150-152$ & 214.21 & 2.29 & 0.57 \\
\hline $23 \mathrm{X}-6,30-32$ & 214.51 & 2.21 & 0.52 \\
\hline
\end{tabular}


Table 2 (continued).

\begin{tabular}{|c|c|c|c|}
\hline $\begin{array}{l}\text { Core, section, } \\
\text { interval }(\mathrm{cm})\end{array}$ & $\begin{array}{l}\text { Depth } \\
\text { (mbsf) }\end{array}$ & $\begin{array}{c}\delta^{18} \mathrm{O} \\
(\% \mathrm{PDB})\end{array}$ & $\begin{array}{c}\delta^{13} \mathrm{O} \\
(\% \text { PDB })\end{array}$ \\
\hline $23 \mathrm{X}-6,150-152$ & 215.71 & 2.26 & 0.44 \\
\hline $23 \mathrm{X}-\mathrm{CC}$ & 216.01 & 2.04 & 0.51 \\
\hline $24 X-1,20-22$ & 216.41 & 2.50 & 0.24 \\
\hline $24 X-1,68-72$ & 216.90 & 2.52 & -0.01 \\
\hline $24 X-1,88-90$ & 217.09 & 2.36 & -0.21 \\
\hline $24 X-1,100-102$ & 217.21 & 2.36 & 0.37 \\
\hline $24 X-1,110-112$ & 217.31 & 2.47 & 0.31 \\
\hline $24 \mathrm{X}-1,110-112$ & 217.31 & 2.54 & 0.16 \\
\hline $24 \mathrm{X}-2,20-22$ & 217.91 & 2.30 & 0.53 \\
\hline $24 X-2,68-72$ & 218.40 & 2.32 & 0.37 \\
\hline $24 X-2,88-90$ & 218.59 & 2.33 & 0.35 \\
\hline $24 X-2,88-90$ & 218.59 & 2.27 & 0.05 \\
\hline $24 X-2,130-132$ & 219.01 & 2.40 & 0.54 \\
\hline $24 X-3,70-72$ & 219.91 & 2.33 & 0.45 \\
\hline $24 X-3,88-90$ & 220.09 & 2.58 & 0.43 \\
\hline $24 X-4,10-12$ & 220.81 & 2.29 & 0.95 \\
\hline $24 X-5,40-42$ & 222.61 & 1.96 & 0.53 \\
\hline $24 X-5,88-90$ & 223.10 & 2.14 & 0.35 \\
\hline $24 X-5,140-142$ & 223.60 & 1.97 & 0.11 \\
\hline $24 X-5,10-12$ & 223.71 & 2.02 & 0.05 \\
\hline $24 \mathrm{X}-6,120-122$ & 224.91 & 1.97 & 0.04 \\
\hline $25 X-2,58-62$ & 227.80 & 2.55 & 0.52 \\
\hline $25 X-3,110-112$ & 229.81 & 2.58 & 0.54 \\
\hline $25 X-4,58-62$ & 230.80 & 2.86 & 0.54 \\
\hline $25 X-6,20-22$ & 233.41 & 3.33 & 0.20 \\
\hline \multicolumn{4}{|l|}{ 114-704B- } \\
\hline $1 \mathrm{H}-2,60-62$ & 2.11 & 2.42 & 0.81 \\
\hline $1 \mathrm{H}-3,44-46$ & 3.45 & 2.13 & 0.09 \\
\hline $1 \mathrm{H}-5,19-21$ & 6.20 & 2.17 & 0.37 \\
\hline $2 \mathrm{H}-1,7-9$ & 6.78 & 2.53 & 0.71 \\
\hline $2 \mathrm{H}-1,107-109$ & 7.78 & 2.00 & 0.48 \\
\hline $3 \mathrm{H}-1,60-62$ & 16.81 & 3.69 & -0.68 \\
\hline
\end{tabular}

Table 2 (continued).

\begin{tabular}{|c|c|c|c|}
\hline $\begin{array}{l}\text { Core, section, } \\
\text { interval }(\mathrm{cm})\end{array}$ & $\begin{array}{l}\text { Depth } \\
\text { (mbsf) }\end{array}$ & $\begin{array}{c}\delta^{18} \mathrm{O} \\
(\% \text { PDB })\end{array}$ & $\begin{array}{c}\delta^{13} \mathrm{O} \\
(\% \mathrm{PDB})\end{array}$ \\
\hline $3 \mathrm{H}-1,60-62$ & 16.81 & 3.68 & -0.85 \\
\hline $3 \mathrm{H}-1,94-96$ & 17.15 & 3.33 & -0.74 \\
\hline $3 \mathrm{H}-1,94-96$ & 17.15 & 3.27 & -0.81 \\
\hline $3 \mathrm{H}-1,140-142$ & 17.61 & 3.37 & -0.83 \\
\hline $3 \mathrm{H}-1,140-142$ & 17.61 & 3.33 & -0.60 \\
\hline $3 \mathrm{H}-4,20-22$ & 20.91 & 3.48 & -0.80 \\
\hline $3 \mathrm{H}-4,60-62$ & 21.31 & 3.46 & -0.84 \\
\hline $3 \mathrm{H}-4,94-96$ & 21.65 & 3.39 & -0.77 \\
\hline $3 \mathrm{H}-4,140-142$ & 22.11 & 3.44 & -0.86 \\
\hline $3 \mathrm{H}-5,20-22$ & 22.41 & 3.55 & -0.40 \\
\hline $4 \mathrm{H}-1,70-72$ & 26.41 & 3.41 & -0.88 \\
\hline $4 \mathrm{H}-1,105-107$ & 26.76 & 2.50 & -0.27 \\
\hline $4 \mathrm{H}-1,120-122$ & 26.91 & 2.98 & -0.84 \\
\hline $4 \mathrm{H}-1,145-147$ & 27.16 & 3.44 & -0.75 \\
\hline $4 \mathrm{H}-1,145-147$ & 27.16 & 3.44 & -0.77 \\
\hline $4 \mathrm{H}-2,30-32$ & 27.51 & 3.22 & -0.21 \\
\hline $4 \mathrm{H}-2,30-32$ & 27.51 & 2.79 & -0.06 \\
\hline $4 \mathrm{H}-2,105-107$ & 28.26 & 3.25 & -0.93 \\
\hline $4 \mathrm{H}-2,120-122$ & 28.41 & 2.68 & -1.02 \\
\hline $4 \mathrm{H}-3,30-32$ & 29.01 & 2.42 & 0.81 \\
\hline $4 \mathrm{H}-4,70-72$ & 30.91 & 3.12 & -0.68 \\
\hline $4 \mathrm{H}-4,105-107$ & 31.26 & 3.15 & -0.14 \\
\hline $4 \mathrm{H}-4,120-122$ & 31.41 & 2.92 & -0.14 \\
\hline $4 \mathrm{H}-4,145-147$ & 31.66 & 2.81 & -0.35 \\
\hline $4 \mathrm{H}-5,38-42$ & 32.10 & 1.61 & 0.13 \\
\hline $4 \mathrm{H}-5,70-72$ & 32.41 & 3.02 & -0.68 \\
\hline $4 H-5,105-107$ & 32.76 & 3.01 & -0.76 \\
\hline $4 \mathrm{H}-6,30-32$ & 33.51 & 2.03 & -1.09 \\
\hline $5 \mathrm{H}-5,51-52$ & 41.71 & 3.18 & -0.79 \\
\hline $5 \mathrm{H}-5,93-95$ & 42.14 & 2.29 & -0.34 \\
\hline $5 \mathrm{H}-6,125-127$ & 43.96 & 3.23 & -0.93 \\
\hline $5 \mathrm{H}-7,15-17$ & 44.36 & 2.71 & 0.07 \\
\hline $6 \mathrm{H}-7,20-22$ & 53.90 & 2.48 & 0.24 \\
\hline
\end{tabular}

